\title{
EQUILIBRIUM STUDIES WITH CERTAIN ACIDS AND MINERALS AND THEIR PROBABLE RELATION TO THE DECOMPOSITION OF MINERALS BY BACTERIA
}

BY

DOUGLAS WRIGHT, JR.

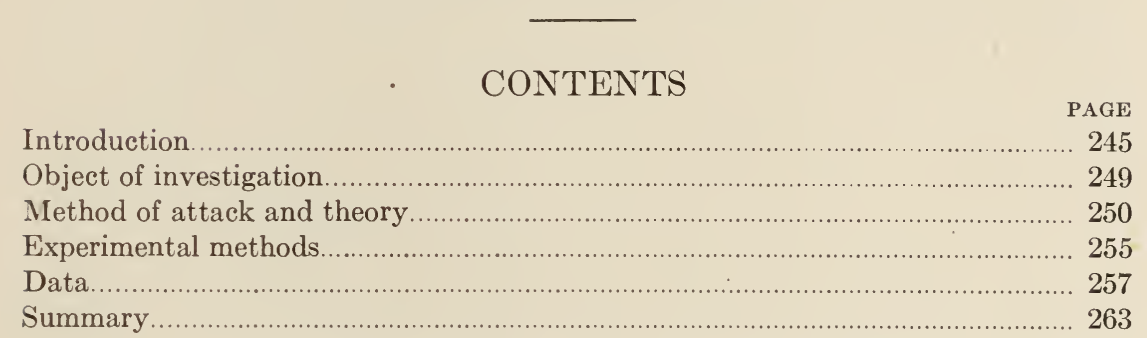

\section{INTRODUCTION}

The importance of the bacterial population to the soil is well recognized. The rôle of micro-organisms in the processes of ammonification, of nitrification, and of nitrogen fixation has been the subject of so much investigation, and has been reviewed so often in the literature that it is generally accepted as fact. The influence of bacterial life, or of the endproducts resulting therefrom, causing as it does the solution of necessary plant nutrients from the mineral particles within the soil, has been the object of much speculation, some of which has been substantiated by experiment. Aside from this effect of bacteria upon the mineral particles within the soil, there is some reason for believing that rocks may undergo disintegration and degradation into soil through the action of bacteria. This subject has been discussed and investigated at some length by various writers, whose work will be mentioned later.

The formation of the mineral portion of the soil is due to the operation upon the rock mass of three general factors, namely, changes in 
physical environment, chemical action, and biological activity. The first of these exerts so apparent an influence upon rocks that it has long been recognized and subjected to careful investigation by geologists. As applied to soils, these effects belong in the realm of the soil physicist and therefore will not be considered in this paper.

The chemical agencies chiefly instrumental in breaking down and dissolving mineral material are water, solutions of varying amounts of $\mathrm{NH}_{3}$ and $\mathrm{CO}_{2}$, various salts, organic acids, and organic compounds. The effect of solutions, especially of neutral salts, has been the subject of extensive investigation. This work will be reviewed later in the section of this paper dealing with method of attack and theory.

Certain biological activities are generally acknowledged to be operative in breaking down the rock mass and preparing it for use as a suitable medium for the growth of plants. Some of these are mechanical, such as the manifest action of roots in prying apart portions of rock. Other effects on rocks are far less easily discernible, due to the slight action of a vast population of microscopic flora found upon rock in all stages of its decomposition. The growth of algae, both alone and in their symbiotic relationships with the lichens, may aid, through the effect of respiration products, in the solution of minerals. It is likely, however, that the more important office of these simple green plants is to serve directly or indirectly as a source of energy for the growth of the still smaller organisms - the bacteria-in situations where the supply of organic materials is limited.

A statement concerning the effect of bacteria in rock decomposition was made by Müntz" as early as the year 1890. He found bacteria "in the denuded rocks of the Alps, the Pyrenees, the Auvergne, and the Vosges comprising the most varied mineralogical types: granites, porphyries, gneiss, mica schist, volcanic rocks, limestones, and sandstones, . . Often the action is not confined to the surface, but extends into the depth of the rock mass. This is the case with the so-called rotten rocks of which the particles become disengaged and separate as is often seen in limestones, schists, and granites. . . . In decomposed rocks I have always verified the presence of nitrifying organisms."

Branner ${ }^{2}$ takes issue with Müntz's assumptions, citing the' need of bacteria for a large supply of oxygen and nitrogen, and their saprophytic habit as prohibitive of their growth to any extent upon or in rocks. Harl Branner's statements been made some years later, they undoubtedly would have been modified by recent information concerning the nitrogen compounds of the fundamental rocks. The investigations of Hall and Miller ${ }^{3}$ show that part of the nitrogen in certain 
clay soils may have been derived from the nitrogen compounds in the rocks from which those soils were formed.

Merrill ${ }^{4}$ mentions bacteria as possible agencies in the decomposition of rocks.

Renault ${ }^{5}$ found bacteria present in coal, and postulates their action in coal beds as that of the transformation of carbonaceous material into methane and hydrogen.

Holland ${ }^{6}$ suggests that the phenomenon of laterization may be due to the action of bacteria, possibly to some specific organism allied to the sulfur and iron bacteria, and gives certain observations which lead to this belief.

Lacroix ${ }^{7}$ makes the following statement: "The bare rocky islet of Cabras, near San Thome in the Gulf of Guinea, is covered with a mantle of slightly ferruginous aluminum phosphate which is sometimes several centimeters thick. This has originated from the interaction of some of the products of bird guano and the underlying rock, aided, doubtless, by microbes."

All the conclusions in the literature mentioned thus far are of a conjectural character and are the result of observation only, no controlled or investigational work having been presented in support of the opinions offered. The most important systematic investigation of the action of bacteria on rocks was undertaken by K. Bassalik ${ }^{8}$, and is reported by him in two papers, The Decomposition of Silicates by Soil Bacteria, and The Decomposition of Silicates by Soil Bacteria and Yeasts.

The first of these papers is more or less preliminary, the author drawing the conclusion that bacteria are able to derive their necessary mineral nutrients from the feldspars, and that appreciable quantities of unweathered orthoclase are dissolved by bacteria, probably by means of $\mathrm{CO}_{2}$ produced by the latter.

The second paper reports an elaborate study of the effect of the growth of several organisms upon various minerals. B. extorquens, several of the nitrifying organisms, butyric acid bacteria, and yeasts were tried upon twelve widely varying silicates and upon apatite. A partial summary of Bassalik's results is given here:

1. Bacteria are able by means of their products of respiration to cause a significant solubility of pulverized silicates.

2. Those which produce organic acids, as Clostridium Pasteurianum, influence more strongly the solubility of the silicates.

3. In the action of micro-organisms upon rocks, the intensity of contact of the organism and the mineral to be dissolved is of greater importance than the various agents of solubility.

4. Thus, $B$. extorquens, which produces only $\mathrm{CO}_{2}$, has the strongest solvent effect through its close and firm envelope of the mineral particles. 
5. Yeasts, which produce much more $\mathrm{CO}_{2}$ in cultures than $B$. extorquens, cause a smaller solubility because of the absence of the close contact with the mineral particles.

6. The nitrite bacteria are also able to effect a significant solubility of silicates as the result of their physiological property of oxidizing $\mathrm{NH}_{3}$, but they affect those minerals rich in alkaline earths much more than those rich in silicates.

7. The significant solubility of apatite seems to be a property only of those bacteria which produce organic acids, for this mineral is dissolved only in moderate degree by those organisms which produce $\mathrm{CO}_{2}$.

8. In the filtrates of the bacterial cultures, especially with $B$. extorquens, can be recovered all the chemical constituents present in the minerals experimented with. Those most easily going into solution are the alkalis, then the alkaline earths and iron, silicic acid much less, and clay the least.

This summary presents some interesting conclusions; and a close review of the paper shows that they are the result of careful work. Bassalik, however, does not get at the fundamental causes of the differences in the effects of organisms. This investigator refers, in conclusions 3,4 , and 5 , to the closeness of contact of organisms to the mineral as an important factor in determining the magnitude of the action of $B$. extorquens; but he does not offer plausible proof of this assumption, and it would seem that his conclusion concerning this point may be erroneous. If we have in solution $\mathrm{H}_{2} \mathrm{CO}_{3}$ from the production of $\mathrm{CO}_{2}$ by $B$. extorquens, the concentration of the acid should depend upon the partial pressure of the $\mathrm{CO}_{2}$ above the liquid and the rate of $\mathrm{CO}_{2}$ production by the organism. The same should be true with the yeast, and as the yeast, according to Bassalik's own statement, produces $\mathrm{CO}_{2}$ more rapidly than does $B$. extorquens, and if, as he also states, the solubility is effected by the concentration of $\mathrm{CO}_{2}$, the yeast should effect the greater solution of the mineral. This should be true, both in the solution culture and in the solution film surrounding the mineral particles, where the organisms are grown upon the moist mineral. Thus it would seem that any greater effect of $B$. extorquens should be attributed to some specific action on the mineral, such as oxidation, hydration, etc., rather than to $\mathrm{CO}_{2}$. Furthermore, the bacterial envelope, which is referred to as enclosing the mineral particles, may consist of a gelatinous coating produced from the mineral particle itself, rather than of an aggregate of bacteria (this coating being greater where the action upon the mineral is greater).

In $1915 \mathrm{~T}$. Kawamura ${ }^{9}$ described an organism found in some volcanic material upon one of the mountains of Japan, at an altitude of 6,600 feet. This organism is of special interest as one which has a specific action upon a silicate material. It forms a zoogloeic mass, the ash of which contains an unusually large amount of silica, 8.873 per cent. Kawamura proposed the name Volcanothrix silicophila for the organism. 
A comprehensive discussion of the action of bacteria upon minerals would not be complete without some reference to the action of certain organisms upon the iron, sulfur, and phosphorus compounds found in rocks and soils. However, since it is the purpose of this paper to deal with an entirely different phase of the subject, a brief reference to the bacterial processes affecting these compounds will suffice.

Lipman and McLean ${ }^{10}$ studied the effect of the oxidation of sulfur upon rock phosphate and found appreciable amounts of the phosphate dissolved through the action of the resulting acid.

Stoklasa ${ }^{11}$ found marked solubility of bone meal through the action of soil bacteria and attributed it to the action of enzymes upon the bone meal.

Koch and Kroeber ${ }^{12}$ and later Kroeber ${ }^{13}$ determined the solubility of different forms of phosphate in the acids produced by the growth of soil and sewage organisms upon dextrose. Kroeber concluded that the acids produced by bacteria and yeasts in the soil may be of great importance in rendering phosphate soluble. In cultures where $\mathrm{CaCO}_{3}$ was present little or no phosphate was made soluble.

Sackett, Patten, and Brown ${ }^{14}$ in a somewhat similar work found that there was a decided solution of the insoluble phosphate when bacterial growth was accompanied by acid formation. They believed that acid is not the sole solvent.

Hopkins and Whiting ${ }^{15}$ discuss the effect upon rock phosphate of the nitrous acid produced through the oxidation of $\mathrm{NH}_{3}$ by Nitrosomonas.

\section{OBJECT OF INVESTIGATION}

Bacteria may effect the solution and disintegration of minerals in at least two ways:

1. Through the oxidation or reduction of one or more of the constituents of the mineral by specific organisms.

2. By the action of some end-product of bacterial activity: i. e., $\mathrm{H}$ ion resulting from acid produced, or $\mathrm{OH}$ ion from the production of $\mathrm{NH}_{3}$.

In the present investigation some of the fundamental considerations in connection with the second phase of the subject were studied, the work being limited to the effect of acid end-products. In none of the work reviewed in the foregoing section have attempts been made to obtain results which may be used to determine whether the action of bacteria upon minerals may follow the usual chemical laws, or at least 
present some constant relationship which may be expressed in an empirical formula. The work in hand has had for its object the procurement and interpretation of data suitable for the confirmation of some such relationship.

\section{METHOD OF ATTACK AND THEORY}

In order to obtain such data it was found necessary to use a different method of attack from that usually pursued in a bacteriological problem. The most common approach to such a problem is by the determination, either in solution culture, in sand culture, or in culture upon the moist pulverized mineral itself, of the amount of material made soluble by the growth of certain organisms. This method gives a series of isolated results, which, though no doubt interesting in themselves, are entirely unrelated either among themselves or to any factor which may control the magnitude of the bacterial effect. In dealing with the phase of the problem studied in this paper, a different method is employed, a method by which it is hoped to show a certain relationship between $\mathrm{H}$ ion produced by bacteria and the amounts of bases brought into solution.

The magnitude of the effect of bacterial end-products upon a mineral will depend upon the equilibrium involving that end-product and mineral. As stated before, in this study it is elected to deal with cases in which acids are the end-products in question. Therefore, it was deemed necessary first to study the equilibria of certain acids, used over a wide range of concentrations, with certain minerals. The object of these equilibrium studies was to compare the $\mathrm{H}$ ion concentrations of the acids, at the various molar concentrations, with the amounts of material which are brought into solution, so to speak, by these $\mathrm{H}$ ion concentrations. Later, studies were made of the $\mathrm{H}$ ion production by certain organisms, and of the equilibria involving these acids and the minerals, the $\mathrm{H}$ ion and the amounts of material in solution being determined.

There is an extensive literature dealing with the equilibria of various soils and minerals in contact with solutions of acids, of bases, and of salts. This literature deals largely with the absorption of bases by soils and minerals, and with the exchange of bases between solution and soil or solution and mineral. In nearly every instance, however, the data are insufficient to warrant their use for substitution in formulae. 
The earlier work is so ably and completely reviewed by Sullivan, ${ }^{16}$ in his consideration of The Interaction between Minerals and Water Solutions, that it seems advisable to refer the reader to that excellent résumé rather than to attempt a repetition here. This review covers the work of Thompson, ${ }^{17}$ Way, ${ }^{18}$ Eichhorn, ${ }^{19}$ Henneberg and Stohmann, ${ }^{20}$ Lemberg, ${ }^{21}$ Peters, ${ }^{22}$ Liebig, ${ }^{23}$ Rautenberg, ${ }^{24}$ Van Bemmelen, ${ }^{25}$ Armsby, ${ }^{26}$ and Boedeker, ${ }^{27}$ and deals largely with the controversy of the physical process of adsorption versus chemical reaction as the cause of the absorption and exchange of bases in soils.

The work of Dittrick ${ }^{28}$ is not included above. His work is reported in two papers, and covers experiments with a granite and an amphibole paridotite, and solutions of $\mathrm{KC} 1, \mathrm{NaC} 1, \mathrm{NH}_{4} \mathrm{C} 1, \mathrm{CaC1}_{2}, \mathrm{MgC1}_{2}, \mathrm{KNO}_{3}$, $\mathrm{K}_{2} \mathrm{SO}_{4}$, and $\mathrm{K}_{2} \mathrm{CO}_{3}$, in the concentrations $\mathrm{N} / 1, \mathrm{~N} / 10$, and $\mathrm{N} / 100$. $\mathrm{He}$ found $\mathrm{Ca}$ and $\mathrm{Mg}$ dissolved by the solutions, the least by $\mathrm{N} / 1$ solution, more by the $\mathrm{N} / 10$ solution, and most by the $\mathrm{N} / 100$ solution. The amount of exchange was greater with the more decomposed rock. Repeated extraction with solutions removed roughly twice as much material as a single extraction.

The action of an acid upon a silicate is really an exchange of $\mathrm{H}$ ion for any of the bases which come into solution through its action. This exchange is a reversible chemical reaction, and as such should conform with the chemical laws applicable to such reactions.

Let us consider a simple case of reversible reaction, or balanced action, that of the union of hydrogen and iodine to form hydriodic acid: $\mathrm{H}_{2}+\mathrm{I}_{2} \approx 2 \mathrm{HI}$.

In this reaction there is a point of equilibrium which is represented by the equation:

$$
\frac{\mathrm{C}_{\mathrm{H} 2} \times \mathrm{C}_{\mathrm{I} 2}}{\mathrm{C}_{\mathrm{H} \mathrm{I}}^{2}}=\frac{\mathrm{k}_{1}}{\mathrm{k}}=\mathrm{K}
$$

This is an example of homogeneous equilibrium, involving the gaseous phase only.

A somewhat different case is encountered with the decomposition of calcium carbonate into carbon dioxide and calcium oxide:

$$
\mathrm{C}_{2} \mathrm{CO}_{3} \approx \mathrm{CaO}+\mathrm{CO}_{2} \text {. }
$$

Here we have both gaseous and solid phases. The amount of gas taking part in the reaction may be measured by its pressure, but the solid must be considered in a different light. This reaction may be considered as taking place in the gaseous phase, the solids present furnishing a constant supply of $\mathrm{CaCO}_{3}$ and $\mathrm{CaO}$ vapor. Then if $\mathrm{C}$ is the 
pressure of $\mathrm{CaCO}_{3}, \mathrm{C}_{1}$ the pressure of $\mathrm{CaO}$, and c the pressure of $\mathrm{CO}_{2}$ at equilibrium, the equation at equilibrium is:

$$
\mathrm{kC}=\mathrm{k}_{1} \mathrm{C}_{1} \mathrm{c} \text {, or } \mathrm{c}=\frac{\mathrm{kC}}{\mathrm{k}_{1} \mathrm{C}_{1}}=\mathrm{K}
$$

Going farther we have the following as a reaction in which we have a solid and a gas on both sides of the equation:

$$
\mathrm{H}_{2} \mathrm{O}+\mathrm{Fe} \approx \mathrm{FeO}+\mathrm{H}_{2}
$$

Let $\mathrm{c}$ be the concentration of $\mathrm{H}_{2} \mathrm{O}$, C that of $\mathrm{Fe}, \mathrm{C}_{1}$ of $\mathrm{FeO}$, and $\mathrm{c}_{1}$ of $\mathrm{H}_{2}$. At equilibrium we then have the equation:

$$
\begin{aligned}
& \text { k c } \mathrm{C}=\mathrm{k}_{1} \mathrm{c}_{1} \mathrm{C}_{1} . \\
& \text { and } \frac{\mathrm{c}}{\mathrm{c}_{1}}=\frac{\mathrm{k}_{1} \mathrm{C}_{1}}{\mathrm{kC}}=\mathrm{K} \\
& \text { or } \frac{\mathrm{c}}{\mathrm{c}_{1}}=\mathrm{K}
\end{aligned}
$$

Now applying this last equation to a case where we have a solution of a salt acting upon a solid to form another salt in solution and a solid we will take the following reaction:

$$
\mathrm{BaSO}_{4}+\mathrm{Na}_{2} \mathrm{CO}_{3} \approx \mathrm{Na}_{2} \mathrm{SO}_{4}+\mathrm{BaCO}_{3} \text {. }
$$

Let $\mathrm{C}, \mathrm{c}, \mathrm{c}_{1}$ and $\mathrm{C}_{1}$ be the respective concentrations of the reacting substances. Then from the above equation

$$
\begin{aligned}
& \frac{\mathrm{c}}{\mathrm{c}_{1}}=\mathrm{K}, \\
& \text { or } \frac{\mathrm{C}_{\mathrm{Na}_{2} \mathrm{CO}_{3}}}{\mathrm{C}_{\mathrm{Na}_{2} \mathrm{SO}_{4}}}=\mathrm{K} .
\end{aligned}
$$

This last equation shows that the equilibrium point is measured by the ratio of concentrations of the soluble reacting materials. As stated by Walker:29 "The active masses of the barium salts may be accounted constant in the reaction, for although they are generally spoken of as 'insoluble', they are in reality measurably soluble in water. The aqueous liquid in contact with them will be and remain saturated with respect to them, i.e., their concentration and active mass in the solution will be constant. The equilibrium will thus be determined by a certain ratio of the concentrations of the soluble sodium salts, independent of what the actual values of the concentrations may be."

A mineral in contact with an acid solution is very similar to the last case cited above, and at any concentration of the acid the equilibrium should be measured by the ratio

$$
\frac{\text { concentration of the acid }}{\text { concentration of the material in solution }}=\mathrm{K}
$$

when these are measured at equilibrium. 
The $\mathrm{H}$ ion is usually assumed to be the measure of the active acid. In acid solution the $\mathrm{H}$ ion concentration is some function of the molar concentration of the acid. Since gas chain measurements yield values which approach the theoretical $\mathrm{H}$ ion concentration, determinations of the $\mathrm{H}$ ion concentrations, $\mathrm{C}_{\mathrm{h}}$, by this method may be substituted for "concentration of acid" in the above formula and the ratio

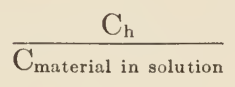

will be constant.

When dealing with materials as complex in their chemical structure as are minerals, it is recognized that a rigid adherence to the theoretical laws can not be expected, and it becomes necessary, therefore, for a comprehensive knowledge of such reactions as are considered in this paper, to resort to certain empirical formulae. It is obviously impracticable to attempt to consider in the term "concentration of material in solution," as used in the formula above, all the bases which may be present in the solution in contact with the mineral at equilibrium. These considerations lead to the assumption that any one of the bases may be taken as measuring the magnitude of the action of the acid on the mineral. Consequently, it is suggested that the formula thus far developed theoretically, be changed to the empirical formula

$$
\frac{\mathrm{C}_{\mathrm{h}}}{\mathrm{C}_{\mathrm{a}}}=\mathrm{K}
$$

where $\mathrm{C}_{\mathrm{h}}$ is the concentration of hydrogen ion, and $\mathrm{C}_{\mathrm{a}}$ represents the molar concentration of $\mathrm{Ca}, \mathrm{Mg}, \mathrm{Fe}$, or $\mathrm{K}$ in solution at equilibrium with the acid.

Since it is desired to study the initial $\mathrm{H}$ ion concentration with respect to $\mathrm{Ca}, \mathrm{Mg}, \mathrm{Fe}$, or $\mathrm{K}$ in solution, it becomes necessary to add a still further modification to the empirical formula-namely, the expression of the initial $\mathrm{H}$ ion concentration in terms of, or as some function of, the $\mathrm{H}$ ion concentration at equilibrium. It is found that this is an exponential function of the $\mathrm{H}$ ion concentration at equilibrium. (See fig. 0.) In this figure, $\log . \mathrm{C}_{\mathrm{h}}$ of the acid alone is plotted against log. $\mathrm{C}_{\mathrm{h}}$ of acid in contact with the mineral. The resulting graph is a straight line, indicating that the ratio is constant, at least over a certain range of concentrations. Thus $\mathrm{C}_{\mathrm{h}}$ of the acid alone is a logarithmic or exponential function of $\mathrm{C}_{\mathrm{h}}$ of the acid in contact with the mineral, or $\mathrm{C}_{\mathrm{h}}=\mathrm{C}_{\mathrm{h}}^{\mathrm{x}}$. Then the equation $\frac{\mathrm{C}_{\mathrm{h}}}{\mathrm{C}_{\mathrm{a}}}=\mathrm{K}$ becomes $\frac{\mathrm{C}_{\mathrm{b}}^{\mathrm{x}}}{\mathrm{C}_{\mathrm{a}}}=\mathrm{K}$, where $\mathrm{C}_{\mathrm{h}}^{\mathrm{x}}$ is the 
initial $\mathrm{H}$ ion concentration of the acid, $\mathrm{C}_{\mathrm{a}}$ the concentration of $\mathrm{Ca}, \mathrm{Mg}$, $\mathrm{Fe}$, or $\mathrm{K}$ in solution at equilibrium, and $\mathrm{K}$ is a constant. This equation is the one used in the consideration of the data contained in this paper.

The formation of acid as the end-product of bacterial activity is a property common to many organisms including many which are commonly found in soils. Acid production by bacteria has been the subject of many investigations. It is used as a means for identifying the various members of the Colon group of bacteria, and consequently the fermentation of sugars by this group has been widely studied. A review of the entire field will not be attempted, but it is well to mention work having a more or less direct bearing upon the subject in hand.

Harden ${ }^{30}$ studied the Chemical Action of B. coli communis and Similar Organisms on Carbohydrates and Allied Compounds. He found that the lactic acid produced never exceeds one-half of the sugar fermented. The amount of acid formed varies with the different sugars.

In a later study with Penfold ${ }^{31}$ he used B. coli on a medium composed of 2 per cent glucose and 1 per cent peptone. He gets of alcohol, acetic acid, formic acid, $\mathrm{CO}_{2}$, lactic acid, and succinic acid, respectively . 17.22 per cent, 20.60 per cent, 2.55 per cent, 17.30 per cent, 40.60 per cent, and 4.80 per cent of the sugar used. With a selected strain of $B$. coli, the lactic acid reaches 70 per cent of the amount of sugar used.

Michaelis and Marcor'a ${ }^{32}$ find that the highest degree of acidity produced by $B$. coli at $37^{\circ} \mathrm{C}$. is $1 \times 10^{-5}$.

In the lactic acid fermentation of sugars, Claflin ${ }^{33}$ notes the formation also of formic, propionic, and acetic acids, the acetic acid formation depending upon the degree of aeration. Ninety-five to 97 per cent of the sugar may be converted into lactic acid, with a very low production of volatile acids, not over one-half per cent. He claims that the nature of the acid produced depends upon the organism and not upon the nature of the medium.

In the present work it must be shown what is the amount of acid, or rather the $\mathrm{H}$ ion concentration, produced by the organisms upon the carbohydrate media used, and what is the effect of this concentration upon the minerals. Is this effect similar to that of the acids alone? 


\section{EXPERIMENTAL METHODS}

As suggested in the foregoing section, the experimental work is divided into two parts, the first consisting of the equilibrium studies with the minerals and acid solutions, the second of bacteriological studies.

Equilibrium studies.-The acids used were hydrochloric, sulfuric, oxalic, phosphoric, lactic, formic, and acetic. It will be observed that these acids vary in the degree of dissociation for any given concentration, hydrochloric acid being the most highly dissociated, and acetic acid being the least ionized. The minerals were calcium silicate, orthoclase feldspar, biotite, and granite. They were ground in a ball mill to pass a 200-mesh sieve. The acids were used in the concentrations: $\mathrm{N} / 5$, $\mathrm{N} / 25, \mathrm{~N} / 50, \mathrm{~N} / 100, \mathrm{~N} / 250, \mathrm{~N} / 500, \mathrm{~N} / 1,000, \mathrm{~N} / 2,000, \mathrm{~N} / 5,000$, and $\mathrm{N} / 10,000$.

The work was carried on at room temperature. The equilibrium studies were arranged in four series, one for each mineral, and each series contained a sub-series for each acid. 200 cubic centimeters of solution were thoroughly shaken with 5 grams of mineral, Jena glassware being used. The solutions were allowed to remain in contact with the mineral for three days, which time is shown in the following table to be sufficient for equilibrium.

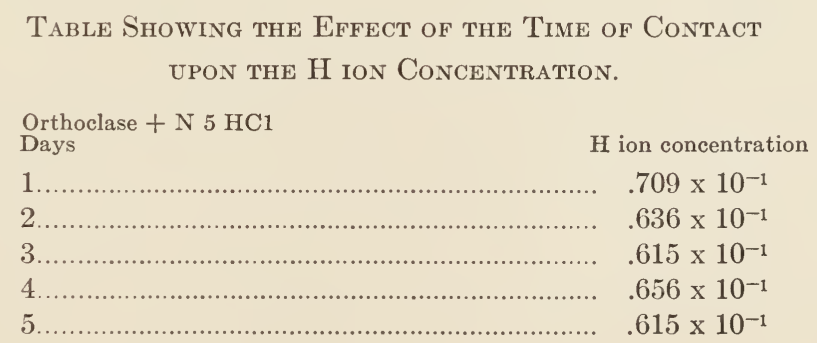

As much as possible of the supernatant solution was then pipetted off and filtered through a Whatman No. 42 filter paper, an unfiltered portion being taken, however, for the $\mathrm{H}$ ion determination. In an aliquot of the filtered solution, calcium, iron, magnesium, and potassium were determined, the calcium and iron by titration with potassium permanganate, the magnesium and potassium gravimetrically as the pyrophosphate and chloroplatinate respectively. 
The $\mathrm{H}$ ion determinations were made by the use of the hydrogen electrode, with the same modifications as were used by Sharp and Hoagland ${ }^{34}$ for soils. These determinations are made both on the acid solutions, and on the acids in contact with the minerals.

A question arose as to the possibility of the formation of a gelatinous coating upon the surface of the mineral, which would hinder the further action of the acid, and prevent attainment of equilibrium. In order to ascertain whether the amount of shaking had been sufficient to remove this film and allow the reaction to come to equilibrium, the following experiment was proposed. A 5-gram portion of mineral was shaken with 200 cc. of $\mathrm{N} / 5 \mathrm{HC} 1$, as in the experimental procedure. The mineral and solution were then poured upon a filter paper, and the mineral was dried and then ground in a mortar. $\mathrm{H}$ ion determinations were made upon the filtrate. The filtrate was poured upon the dried mineral and allowed to remain for three days with frequent shaking. $\mathrm{H}$ ion determinations were again made. The following data show that there is no significant change in $\mathrm{H}$ ion concentration in the second contact of the solution with the mineral:

$\begin{array}{llr} & \mathrm{H} \text { ion Conc. } \\ \text { Calcium silicate }{ }^{+} \mathrm{N} 5 \mathrm{HC1} \ldots .1 \text { st contact...... } & 0.607 \times 10^{-1} \\ \text { Calcium silicate }{ }^{+} \mathrm{N} 5 \mathrm{HC} 1 \ldots .2 \mathrm{~d} \text { contact... } & 0.607 \times 10^{-1} \\ \text { Labradorite } & +\mathrm{N} 5 \mathrm{HC} 1 \ldots .1 \text { st contact..... } & 0.797 \times 10^{-1} \\ \text { Labradorite } & { }^{+} \mathrm{N} 5 \mathrm{HC} 1 \ldots .2 \mathrm{~d} \text { contact...... } & 0.828 \times 10^{-1}\end{array}$

Bacteriological work.-Three organisms were used, Azotobacter, Bacillus coli, and $B$. lactis acidi. The first of these was chosen because of the very high $\mathrm{H}$ ion concentration which it produced upon dextrose solution, nearly $1 . \times 0^{-1}$ as determined by Dr. Waynick in this laboratory. $B$. coli is referred to in the literature previously cited as producing large amounts of acid, and $B$. lactis acidi was taken as a typical acid producer. Azotobacter were grown upon 2 per cent dextrose solution, $B$. coli in a solution of 2 per cent dextrose and 1 per cent peptone as used by Penfold, and $B$. lactis acidi in 1 per cent dextrose. The work was arranged in three series, one for each organism. Each series contained five cultures, each culture containing 1,000 cc. of solution in 1,200 cc. Florence flasks. One culture contained no mineral. The other cultures contained 25 grams of mineral each, one with calcium silicate, one with orthoclase feldspar, another with biotite, and one with granite. These cultures were run for a total time of sixteen days, $\mathrm{H}$ ion determinations being made at $1,2,3,5,7,9,11$, and 16 days, and on each of these days $100 \mathrm{cc}$. of solution was removed for the determination of calcium, iron, magnesium, and potassium. The cultures were grown at a temperature of $28^{\circ} \mathrm{C}$. and the customary bacteriological precautions were observed throughout the work. 


\section{DATA}

The data obtained by the methods given above are reported in tables 1 to 38 inclusive. The amounts of calcium, magnesium, iron, and potassium are calculated and expressed as moles per liter. Both the initial and final $\mathrm{H}$ ion concentrations are also reported as gram molecules per liter. For the convenience of the reader, the logarithms of these numerical values are given in adjacent columns.

Accompanying each table is a graphical representation of the relation between certain series of values given in that table. (Owing to a loss of material during the analysis, tables 3, 9, and 22 are incomplete; there are, therefore, no graphs for these tables.) The logarithms of the $\mathrm{H}$ ion concentrations, $\log . \mathrm{C}_{\mathrm{h}}$, are plotted along the ordinates, and the logarithms of the concentrations of $\mathrm{Ca}, \mathrm{Mg}, \mathrm{Fe}$, or $\mathrm{k}, \log . \mathrm{C}_{\mathrm{a}}$, along the abscissas, and the average curve is drawn through the points thus obtained.

In the section of this paper dealing with "Method of Attack and Theory," certain assumptions are made and ultimately expressed in the empirical formula, $\frac{\mathrm{C}_{\mathrm{h}}^{\mathrm{x}}}{\mathrm{C}_{\mathrm{a}}}=\mathrm{K}$. By substitution of the experimental data in this formula, the values of the constants $\mathrm{x}$ and $\mathrm{K}$ may be calculated. If these values of $\mathrm{x}$ and $\mathrm{K}$ are constant for a given series, then the ratio, $\frac{\mathrm{C}_{\mathrm{h}}^{\mathrm{x}}}{\mathrm{C}_{\mathrm{a}}}$, is constant for that series, and the plotted graph representing that ratio will be a straight line, or conversely, a straight line curve indicates that $\mathrm{x}$ and $\mathrm{K}$ are constant. The straight line graph expresses a direct ratio between series of values, these values being, in this case, the logarithms of $\mathrm{C}_{\mathrm{h}}$ and of $\mathrm{C}_{\mathrm{a}}$.

The exponential constant $\mathrm{x}$ and the reasons for its use have been discussed previously. It expresses the relation of $\mathrm{H}$ ion at equilibrium to the initial $\mathrm{H}$ ion concentration of the acid. That this relationship is of an exponential character may be due to chemical reaction, to adsorption, or to a combination of these phenomena. It is not proposed, however, to differentiate here between adsorption and chemical reaction, the purpose of this work being to provide a means, empirical if necessary, of accounting for the magnitude of the action of acids upon minerals.

The constant $\mathrm{K}$ is the numerical expression of the ratio of the logarithm of the initial $\mathrm{H}$ ion concentration to the logarithm of $\mathrm{Ca}, \mathrm{Mg}$, 
$\mathrm{Fe}$, of $\mathrm{K}$ brought into solution, so to speak, by that $\mathrm{H}$ ion concentration. The numerical magnitude of $\mathrm{K}$ for any table represents the slope or inclination of the graph plotted from that table. The range of values for $\mathrm{K}$ may be very large, varying from infinity, for a horizontal line, to zero, for a vertical line.

Since it is possible to draw a straight line averaging the points plotted from the experimental data, the graphical method is employed for obtaining values of $\log . \mathrm{C}_{\mathrm{h}}$ and $\log$. $\mathrm{C}_{\mathrm{a}}$ for substitution in the equation for the calculation of $\mathrm{x}$ and $\mathrm{K}$. By this means average values of $\mathrm{x}$ and K may be computed without resorting to a calculation of all the possible combinations of equations for which data are available. The use of this procedure eliminates a large part of the tedious mathematical routine, and it is recognized as yielding averages sufficiently close to the statistical average to serve the purpose contemplated in this paper. If the above preliminary remarks are borne carefully in mind, the following consideration of the groups of tables and graphs will be clear.

Tables 1 to 7 contain the data for the equilibria between calcium silicate and the acids. The figures accompanying these tables are sufficient to show that the graph for any given series is a straight line. As stated before, this signifies that $\mathrm{x}$ and $\mathrm{K}$ are constant for each series, and that the reaction of the acid with the mineral takes place in accordance with the formula $\frac{\mathrm{C}_{\mathrm{h}}^{\mathrm{x}}}{\mathrm{C}_{\mathrm{a}}}=\mathrm{K}$. The slope of the graphs, however, seems to become less for the equilibria involving the less dissociated acids, the slope for acetic acid being much less than that for hydrochloric acid. As explained before, this difference in slope is indicated by the following numerical values for the constant ' $K$ calculated from the graphs, the slope becoming less as $\mathrm{K}$ increases:

\begin{tabular}{|c|c|}
\hline HC1. & $\mathrm{K}=0.01391$ \\
\hline Sulfuric acid... & $\mathrm{K}=0.2642$ \\
\hline Phosphoric acid. & $K=0.4448$ \\
\hline Lactic acid... & $K=14.86$ \\
\hline rmic acid.. & $\mathrm{K}=335.5$ \\
\hline etic acid..... & $\mathrm{K}=941.2$ \\
\hline
\end{tabular}

Since, as stated before, the graphs represent ratios of $\log . \mathrm{C}_{\mathbf{h}}$ to $\log . \mathrm{C}_{a}$, and since this ratio varies with the slope of the graph, it would seem, from a comparison of the curves for HC1 and acetic acid, that an acid such as HC1, which is highly ionized, brings smaller amounts of material into solution per unit increase of $\mathrm{H}$ ion than do those acids, acetic for instance, which have a lower ionization constant. This apparent difference in the action of various acids is due undoubtedly to 
the fact that the commercial calcium silicate was used for this work, and that it contained considerable quantities of $\mathrm{CaCO}_{3}$, as shown by the marked effervescence which occurred when the acid was added to this material. The loss of $\mathrm{CO}_{2}$ from the system undoubtedly affected the true equilibrium, and this apparently greater action of the less dissociated acids is the result. As will be seen in the considerations which follow, this difference in effect between various acids occurs only with calcium silicate.

In tables 1 to 7 , as well as in those which follow, there are no data for calcium where oxalic acid is used, because of the insolubility of the resulting calcium oxalate. This fact is mentioned again, and its importance is emphasized further, in connection with a general statement corcerning the action of the $\mathrm{H}$ ion concentration of acids upon minerals.

The data for the various acids and orthoclase are found in tables 8 to 12 inclusive. From a comparison of the corresponding graphs, it is seen that they are quite steep, and that all have approximately the same slope. This observation is verified by a consideration of the constant, $\mathrm{K}$, as calculated for the various members of this group of tables. The fact that $K$ is very small is evidence that the graphs approach the perpendicular, and when it is remembered that the values for $\mathrm{K}$ range from zero to infinity for a change of 90 degrees in slope, it is obvious that the very small range of values for $K$ given here, 0.00002661 to 0.000001427 , represents a very small difference in the slopes of the various curves. The fact that $\mathrm{K}$ is constant for each series, and that the corresponding graph is a straight line, goes to show that the calcium coming into solution is a logarithmic function of the initial $\mathrm{H}$ ion concentration of the acid, and that the assumptions expressed in the formula $\frac{\mathrm{C}_{\mathrm{h}}^{\mathrm{x}}}{\mathrm{C}_{\mathrm{a}}}=\mathrm{K}$ are verified by experimental evidence.

Further proof of these assumptions is offered in the next group of tables, numbers 13 to 19 inclusive, which give the data for the acids in equilibrium with biotite. Data for calcium, magnesium, and potassium in solution are reported. As in the previous series of tables, the graphs for calcium are straight lines and have about the same slope, the extreme range of values for $\mathrm{K}$ being from 0.00005790 to 0.000001071 . The constant $\mathrm{K}$ for the magnesium determinations is more variable, but still no large discrepancy is apparent, the values ranging from 0.04373 to 0.000008395 .

A deviation from the straight line graph is encountered in the figures and tables expressing the equilibria for granite and the acids, 
tables 20 to 26 inclusive. When the logarithms of the data for iron are plotted against the logarithms for $\mathrm{H}$ ion concentrations and the lines are drawn through the points thus obtained, the resulting curves are not straight lines. (See figures 20 to 26.) The flatter portion of the curve occurs in every instance at approximately the value, $\overline{3} .0$, represented by that logarithm of the $\mathrm{H}$ ion concentration, and probably is due to the formation of another compound of iron at that concentration. Since these curves are not straight lines, it is obvious that no constant values for $\mathrm{x}$ and $\mathrm{K}$ may be calculated therefrom, and furthermore it may be inferred that any iron compounds in the mineral do not react with the acids in accordance with the proposed formula. The curves for calcium, however, are straight lines, thus affording still further proof that the assumptions regarding the nature of such reactions are correct as far as calcium is concerned. The graphs have nearly the same slope throughout the series of figures, the values for $\mathrm{K}$ ranging from 0.000001328 to 0.000007799 .

In a general survey of the graphs thus far discussed, instances may be observed in which certain plotted points are far from coincident with the straight line graph. In certain cases, these discrepancies represent error in the determinations. Where they appear in the lower portion of the graph, however, the last two or three points dropping below the curve, they occur because the lower limit of the determination has been reached, and no smaller amounts can be determined with any degree of accuracy.

A consideration of the meaning and the possible relationships of the results thus far reviewed is not inappropriate at this point. It is the opinion of the writer that that type of investigation is the most valuable which has for its object the procurement of data which are related, either among themselves, or to certain controllable factors, and which may be taken as the basis for, or in verification of, some general law suitable either for the explanation of certain phenomena or for direct application in the prediction of future results. Thus a general consideration of the tables and figures leads to the following remarks.

All the straight line graphs for a given mineral, excepting calcium silicate, the deviation of which has been explained, have practically the same slope and give nearly the same values for $x$ and $K$. It follows therefore, that if the curves for one mineral in contact with the various acids be superimposed one upon the other, they will all fall practically in the same straight line. This would seem to indicate, for a given mineral, and within the limits of the concentrations used, that the amount of calcium, magnesium, or potassium coming into solution is a function 
of the $\mathrm{H}$ ion concentration of the acid, regardless of the nature of the acid used, except, and this exception is extremely important, in those cases where the acid forms compounds which are less soluble at any given $\mathrm{H}$ ion concentration than the compounds in the mineral itself. The importance of this exception must be emphasized, and it is illustrated in a very striking manner by the different series with oxalic acid where only traces of calcium are found in solution. It is recognized that this illustration represents an extreme case and that other socalled insoluble compounds may approach the mineral compounds in solubility.

The objection was raised to the foregoing generalization that a $\mathrm{N} / 100$ solution of acetic acid, for instance, contains the same total molar concentration of hydrogen as a N/100 hydrochloric acid solution, regardless of the relative $\mathrm{H}$ ion concentration of these acids. The hydrochloric acid is, of course, the more highly dissociated acid, but will not the slightly dissociated acetic acid continue to give off $\mathrm{H}$ ion as that already in solution combines with the mineral, and should not the ultimate result be the same with the acetic as with the hydrochloric acid for a given molar concentration? That this objection is not substantiated by fact is due doubtless to the following reason. In general the salts of acetic acid are much more highly dissociated than is the acid itself. Consequently, the acetates formed by the contact of acetic acid with the mineral will be fairly highly dissociated, thus supplying the solution at equilibrium with a certain concentration of acetic ion. The presence of this acetate ion will depress or prevent the further ionization of the acetic acid in solution, and thus practically limit the action of the acetic acid to its original $\mathrm{H}$ ion concentration. This same explanation will hold for other slightly dissociated acids.

The general relation existing between the $\mathrm{H}$ ion concentration of acids and the amounts of $\mathrm{Ca}$, of $\mathrm{Mg}$, or of $\mathrm{K}$ in solution, may have the following practical application. It is desired to determine the effect of certain acids upon a mineral. This mineral may be studied in equilibrium with different concentrations of $\mathrm{HCl}$, and the logarithmic graph constructed as in the foregoing mineral series. Any point on this graph represents a ratio of $\log . \mathrm{H}$ ion to $\log . \mathrm{C}_{\mathrm{a}}$, or whatever base it is desired to consider, in solution. Thus, by determining the $\mathrm{H}$ ion concentration of the acid whose action it is desired to predict, we may, by referring to the graph, estimate the magnitude of the effect of the acid upon the mineral, at least within certain limits already discussed. The application suggested above may be made to the effect of acids produced by bacterial growth, and in the prediction of their action upon a given mineral. 
The above application is suggested merely as a possibility, and it is fully recognized that there is room for much further study and research before the existence of such a general relationship can be definitely established. It must be emphasized also that the constants for one mineral and one set of conditions can not be applied directly to another mineral and a different set of conditions. The constants must be determined, and the resulting graph constructed for every application of the relation suggested.

The data obtained from the bacterial series still await consideration. As expressed in tables 26 to 38 , and in the corresponding figures, the action of the acids produced by bacteria seems to differ in magnitude from the action of the acids used in the foregoing series. In regard to this difference, it should be observed that $\mathrm{C}_{\mathrm{h}}$, the $\mathrm{H}$ ion concentration, was determined, for the bacterial series, in solution cultures with no mineral present. Had the bacterial growth been stopped immediately following the $\mathrm{H}$ ion determination, and had this solution then been brought into contact with the mineral, the magnitude of the effect should have been comparable with that of the acid series. Instead, the amounts of material coming into solution were determined in a series parallel with the above, wherein bacteria were grown in solution in contact with the minerals. It had been assumed that the rate of $\mathrm{H}$ ion production would be the same, both in solution culture and in solution in contact with the mineral. This assumption was found to be incorrect. In the mineral cultures the acid was partly neutralized as produced, and the growth of the organism was not inhibited by the increasing concentration of acid as it was in the dextrose solution with no mineral. Consequently, the total $\mathrm{H}$ ion as produced in the mineral cultures, and indicated by the large relative amounts of material coming into solution in these cultures, was much greater than that produced in the parallel series without mineral. Since the data for $\mathrm{H}$ ion, $\mathrm{C}_{\mathrm{h}}$, as expressed in the tables, were obtained from the latter series, it is obvious that the graphs plotted from a ratio of $\mathrm{H}$ ion, as determined in dextrose solution, to material in solution, as determined in the mineral cultures, are not directly comparable with the graphs for the equilibria between acids and minerals.

The lack of agreement between the acid series and the bacterial series is made evident by a review of the curves and the corresponding constants for the bacterial series. The graphs are straight lines, but they have less slope than do those graphs for the corresponding mineral in equilibrium with the acids. For instance, the constant, K, for orthoclase and Azotobacter is 19.77 against a value approaching $10^{-6}$ for 
orthoclase and the acids, and the graph for the former has much less slope than the graph for the latter. The constant, $\mathrm{K}$, for orthoclase and $B$. coli is 13,490 , against $10^{-6}$ for orthoclase and the acids. B. lactis acidi, which produced acid very slowly, is represented by graphs which more nearly resemble those of the acid-mineral series, and the value for $\mathrm{K}$ for calcium from orthoclase, for instance, is 0.0006652. Since discrepancies of the same general nature and magnitude as those just pointed out, are apparent in the other graphs and constants for the bacterial-mineral series, the reader is referred to the graphs and tables for further comparisons.

The important point brought out by the bacterial series is that the graphs for calcium, for magnesium, and for potassium are straight lines, and that $\mathrm{x}$ and $\mathrm{K}$ are constant for a given series. Thus it is shown that the reactions between minerals and the acids produced by bacterial growth, conform with the given empirical formula. Since this same formula has been successfully applied to the chemical equilibria between various acid solutions and the same minerals, it may be concluded that the action of bacterial end-products upon minerals, at least when these end-products are acids, is explainable upon the basis that it is a chemical reaction.

\section{SUMMARY}

Equilibria of certain minerals and various concentrations of acids are studied.

Equilibria of the same minerals with solutions in which bacteria are producing acid are also studied.

The data obtained from the acid-mineral series are applied to the formula $\frac{\mathrm{C}_{\mathrm{h}}^{\mathrm{x}}}{\mathrm{C}_{\mathrm{a}}}=\mathrm{K}$.

It is found that the reactions occurring in the mineral-acid equilibria conform with the given formula.

It is suggested that a general relation exists between the initial $\mathrm{H}$ ion concentration of the acid and the amount of material which the acid brings into solution when in contact with a mineral.

A practical application of the relation just referred to, is suggested.

The data obtained from the bacterial studies are applied to the formula $\frac{\mathrm{C}_{\mathrm{h}}^{\mathrm{x}}}{\mathrm{C}_{\mathrm{a}}}=\mathrm{K}$.

The reactions occurring in the bacterial series also conform with the above formula. 
It is concluded that the action of acid bacterial end-products upon minerals is explainable as a chemical reaction.

The author wishes to express his gratitude to Dr. C. B. Lipman for the suggestion of the problem and for his interest and help during the progress of the work, and to Professor L. T. Sharp and Dr. D. D. Waynick for many helpful suggestions.

Transmitted September 2, 1919.

\section{LITERATURE CITED}

1 Muntz, A.

1890. Chimie agricole. Sur la décomposition des roches et la formation de la terre arable. Compt. Rend. Acad. des Sciences, Paris, vol, 110, pp. 1370-1372.

2 Branner, J. C.

1897. Bacteria and the decomposition of rocks. Am. Jour. of Sci., vol. 153, p. 438 .

${ }^{3}$ Hall, A. D., and Miller, N. H. J.

1908. The nitrogen compounds of the fundamental rocks. Jour. of Agric. Sci., vol. 2, pp. 343-345.

${ }^{4}$ Merrill, G. P.

1895. Disintegration of the granite rocks of the District of Columbia. Bull. Geol. Soc. Am., vol. 6, pp. 321-332.

${ }^{5}$ Renault, B.

1896. Conclusions from an article by Renault entitled, "Les bactéries et leur oeuvre géologique." Nature, vol. 55, p. 40 .

${ }^{6}$ Holland, T. H.

1903. On the constitution, origin and dehydration of laterite. Geol. Mag., vol. 40 , pp. 59-69.

7 Lacroix, A.

1906. Sur la transformation de roches volcaniques en phosphate d'alumine sous l'influence de produits d'origine physiologique. Compt. Rend., Acad. des Sciences, Paris, vol. 143, pp. 661-664.

8 BassaliK, K.

1913a. Decomposition of silicates by soil bacteria. Zeitsch. Garungsphysiol., vol. 2, pp. 1-32.

1913b. Silicate decomposition by soil bacteria and yeasts. Ibid., vol. 3, pp. 15-42.

${ }^{9}$ Kawamura, T.

Studies on "Tengunomugimethi."

10 Lipman, J. G., and McLean, H. C.

1916. The oxidation of sulphur in soils as a means of increasing the availability of mineral phosphates. Soil Science, vol. 1, pp. 533-539.

11 S'TOKLASA, J.

1900. Ueber den Einfluss der Bakterien auf die Knochenzersetzung. Centralblatt für Bakt., Abt. 2, Bd. 6, pp. 554-560. 
12 Koch, A., and Kroeber, E.

1906. Der Einfluss der Bodenbakterien auf das Löslichwerden der Phosphorsäure aus verschiedenen Phosphaten. Fühling's Landwirt. Zeit., vol. 55, pp. 225-235.

13 Kroeber, E.

1909. Ueber das Löslichwerden der Phosphorsäure aus wasserunlöslichen Verbindungen unter der Einwerkung von Bakterien und Hefen. Jour. für Landwirt., vol. 57, pp. 5-80.

14 Sackett, W. G., Patten, A. J., and Brown, C. W.

1908. The solvent action of soil bacteria upon the insoluble phosphates of raw bone meal and natural raw rock phosphate. Michigan Agric. Exper. Station, Special Bull., No. 43, pp. 363-390.

15 Hopkins, C. G., and Whiting, A. L.

1916. Soil bacteria and phosphates. Illinois Exper. Station Bull. No. 190, pp. 395-406.

ie Sullivan, E. C.

1907. The interaction between minerals and water solutions with special reference to geologic phenomena. U. S. Geol. Surv., Bull. 312, pp. 9-64.

17 Thompson, H. S.

1850. On the absorbent power of soils. Jour. Roy. Agric. Soc., vol. 2, pp. 68-74.

18 WAY, J. T.

1850. On the power of soils to absorb manure. Jour. Roy. Agric. Soc., vol. 2, pp. 313-379.

1852. Idem, Second paper, ibid., vol. 13, pp. 123-143.

1854. On the influence of lime on the absorptive properties of soils. Jour. Roy. Agric. Soc., vol. 15, pp. 491-514.

19 FichorN, H.

1858. Ueber die Einwirkung verdunnter Salzlösungen auf Silicate. Pogg. Ann., vol. 105, pp. 126-133.

${ }^{20}$ Henneberg, J. W. J., and Stohmann, F. K. A.

1859. Ueber das Verhalten der Ackererde gegen Lösungen von Ammoniak und Ammoniaksalzen. Jour. für Landwirt. Göttingen, Bd. 7, (Neue Folge, Bd. 3), pp. 25-47.

1858. Ueber das Verhalten der Ackerkrume gegen Ammoniak und Ammoniaksalze. Liebig's Annalen, vol. 107, pp. 152-174.

${ }^{21}$ Lemberg, H. J. von.

1870. Ueber einige Umwandlungen finnländischer Feldspathe. Zeitschr. der deutsch. geol. Gesell., vol. 22, pp. 335-372.

22 Peters, E.

1860. Studien ueber den Boden aus dem Laboratorium zu Tharand. Landw. Versstat., vol. 2, pp. 113-116.

${ }^{23}$ Liebig, J. voN.

1858. Ueber einige Eigenschaften der Ackerkrume. Ann. chem., vol. 105, pp. 109-144.

${ }^{24}$ RaUtenberg, F. von.

1862. Ueber die Absorptionsfähigkeit verschiedener Bodenarten und das geognostitischen Vorkommen derselben. Jour. für Landwirt., vol. 10 , pp. $49-66$. 
25 Van Bemmelen, J. M.

1899. Die Absorption IV. Die Isotherme des kölloidalen Eisenoxyds bei $15^{\circ}$. Zeitschrift für anorg. Chemie, vol. 20, pp. 185-211.

1878. Das Absorptionsvermögen der Ackererde. Landwirt. Versstat., vol. 21, pp. 135-191.

1881. Die Verbindungen einiger fester Dioxydhydrate mit Säuren, Salzen und Alkalien. Jour. für prakt. chemie, Ser. 5, Bd. 131-132, pp. 324349, 379-395.

${ }^{26}$ Armsby, H. P.

1878. Ueber das Absorptionsvermögen des Bodens für Basen. Landwirt. Versstat., vol. 21, pp. 397-405.

${ }^{27}$ Boedeker, C. von.

1859. Ueber das Verhältniss zwischen Masse und Wirkung beim Contact ammoniakalischer Flüssigkeiten mit Ackererde und mit kohlensäurem Kalk. Jour. für Landwirt., vol. 7, pp. 48.

${ }^{28}$ DitTrick, M. von.

1901. Chemisch-geologische Untersuchungen ueber "Absorptionserscheinungen” bei zersetzten Gesteinen. Mitt. grossh. bad. geol. Landesanstalt, vol. 4, pp. 341-366.

1905. Idem, Second paper, ibid., vol. 5, pp. 1-23.

29 WALKER, JAMES.

1913. Introduction to physical chemistry. Macmillan.

${ }^{30}$ HaRden, A.

1901. The chemical action of Bacillus coli communis and similar organisms on carbohydrates and allied compounds. Jour. Chem. Soc. London, vol. 79, pp. 691-698.

${ }^{31}$ Harden, A., and Penfold, W. J.

1912. The chemical action on glucose of a variety of Bacillus coli communis (Escherich) obtained by a culture in presence of chloracetate. Proc. Roy. Soc. London, vol. 85 B, pp. 415-417.

${ }^{32}$ Michaelis, L., and Marcora, F.

1912. Die Säureproduktivität des bacterium coli. Zeitschrift Immunitätsforschung u. exper. Terapie, Bd. 14, pp. 170-173.

${ }^{33}$ Clafilin, A. A.

1912. Products of the lactic fermentation of sugars. Orig. Comm. 8th Intern. Congress Appl. Chem., vol. 25, Appendix, pp. 343-345.

${ }^{34}$ Sharp, L. T., and Hoagland, D. R.

1916. Acidity and absorption in soils as measured by the hydrogen electrode. Jour. Agric. Research, vol. 7, pp. 123-143. 


\section{NOTE}

The following legend refers to all the figures:

$+=$ Curve for Calcium.

0 = Curve for Magnesium.

$\oplus=$ Curve for Potassium or Iron.

The numbers along the ordinates represent the logarithms of the $\mathrm{H}$ ion concentrations, or $\log$. $\mathrm{C}_{\mathrm{h}}$. Those along the abscissas measure the logarithms of the concentrations, or $\log$. $\mathrm{C}_{\mathrm{a}}$, of calcium, magnesium, iron, or potassium.

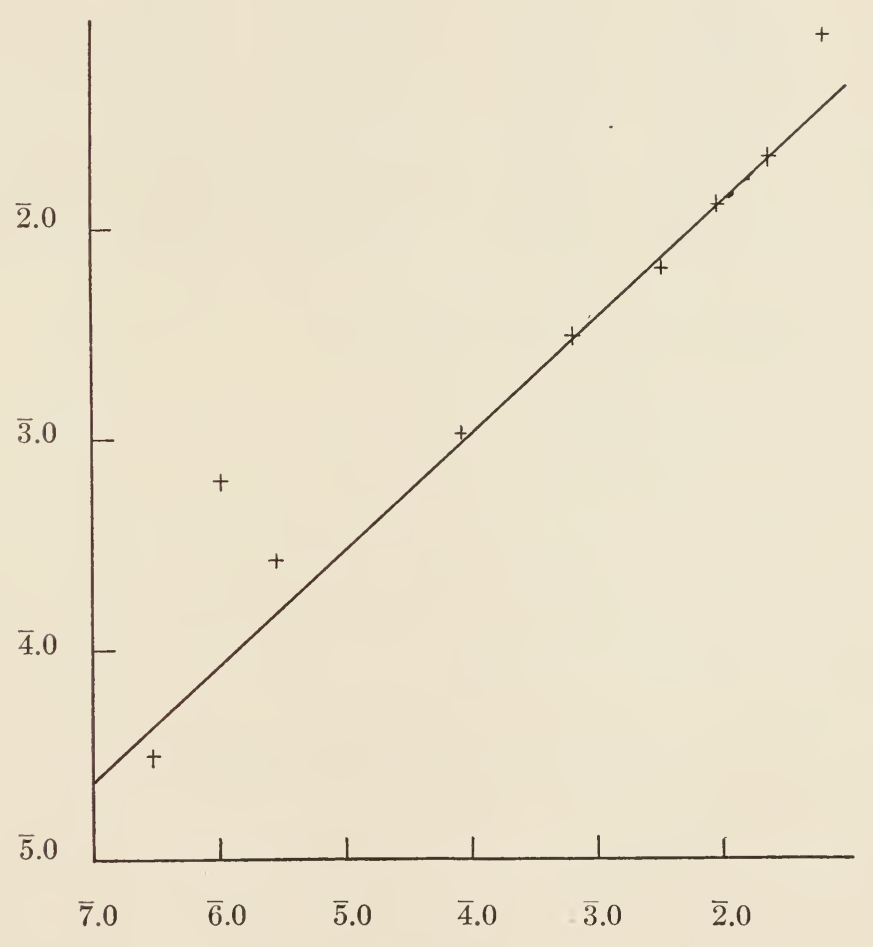

Fig. 0 .

(See Table 8)

Relation of log. $\mathrm{H}$ ion, $\mathrm{HC}$, to $\log$. $\mathrm{H}$ ion, $\mathrm{HC} 1+$ Orthoclase. 
TABLE I

Hydrochloric Acid and Calcium Silicate

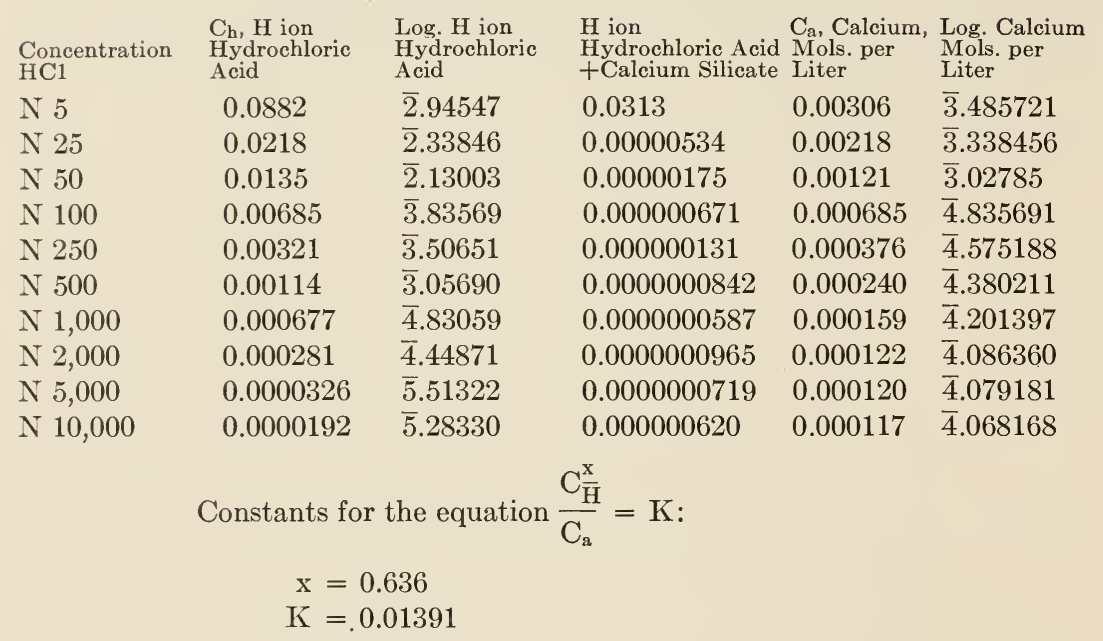




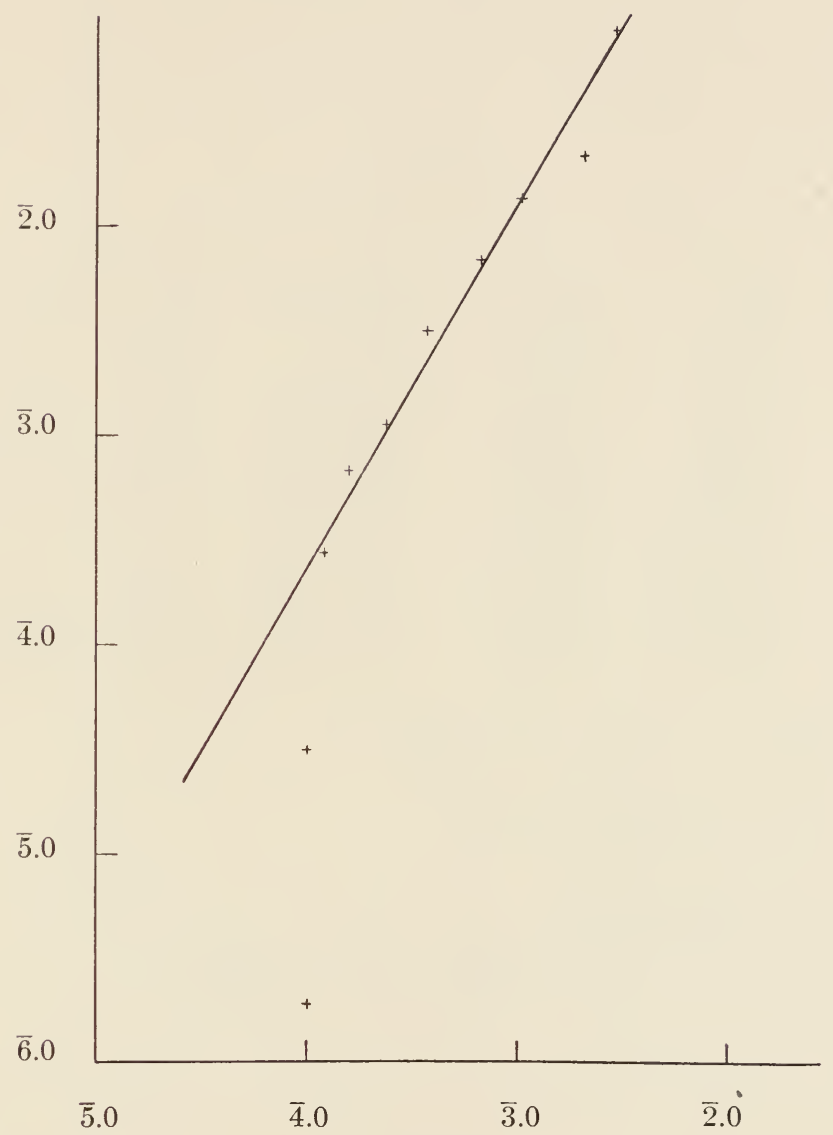

Fig. 1.

Hydrochloris Acid and Calcium Silicate.

(See Table 1) 
TABLE 2

Sulfuric Acid and Calcium Silicate

\begin{tabular}{|c|c|c|c|c|c|}
\hline Concentration & $\begin{array}{l}\mathrm{Ch}_{\mathrm{h}, \mathrm{H} \text { ion }} \\
\text { Sulfuric } \\
\text { Acid }\end{array}$ & $\begin{array}{l}\text { Log. H ion } \\
\text { Sulfuric } \\
\text { Acid }\end{array}$ & $\begin{array}{l}\mathrm{H} \text { ion } \\
\text { Sulfuric Acid } \\
\text { +Calcium Silicate }\end{array}$ & $\begin{array}{l}\text { Ca, Calcium } \\
\text { Mols. per } \\
\text { Liter }\end{array}$ & $\begin{array}{l}\text { Log. Calcium } \\
\text { Mols. per } \\
\text { Liter }\end{array}$ \\
\hline N 5 & 0.0567 & $\overline{2} .75358$ & 0.0300 & 0.00188 & $\overline{3} .274158$ \\
\hline N 25 & 0.0186 & $\overline{2} .26951$ & 0.00000579 & 0.00197 & $\overline{3} .294466$ \\
\hline N 50 & 0.0130 & $\overline{2} .11394$ & 0.000000450 & 0.00115 & $\overline{3} .060698$ \\
\hline N 100 & 0.00632 & $\overline{3} .80072$ & 0.000000203 & 0.000655 & $\overline{4} .816241$ \\
\hline N 250 & 0.00296 & $\overline{3} .47129$ & 0.0000000810 & 0.000356 & $\overline{4} .551450$ \\
\hline N 500 & 0.00162 & $\overline{3} .20952$ & 0.0000000719 & 0.000218 & $\overline{4} .338456$ \\
\hline N 1,000 & 0.000931 & $\overline{4} .96895$ & 0.000000180 & 0.000148 & $\overline{4} .170262$ \\
\hline N 2,000 & 0.000600 & $\overline{4} .77815$ & 0.0000000323 & 0.000099 & $\overline{5} .995635$ \\
\hline N 5,000 & 0.000259 & $\overline{4} .41330$ & 0.0000000235 & 0.000079 & $\overline{5} .897627$ \\
\hline N 10,000 & 0.000174 & $\overline{4} .24055$ & 0.0000000364 & 0.000089 & $\overline{5} .949390$ \\
\hline
\end{tabular}

By graphical average:

$$
\begin{aligned}
\mathrm{x} & =0.799 \\
\mathrm{~K} & =0.2642
\end{aligned}
$$

By calculation:

$$
\begin{array}{cl}
\mathrm{x}=0.858 \pm 0.0074 & \text { C. } \mathrm{v} .=5.99 \% \\
\mathrm{~K}=0.7332 \pm 0.0313 & \text { C. } \mathrm{v} .=29.05 \%
\end{array}
$$




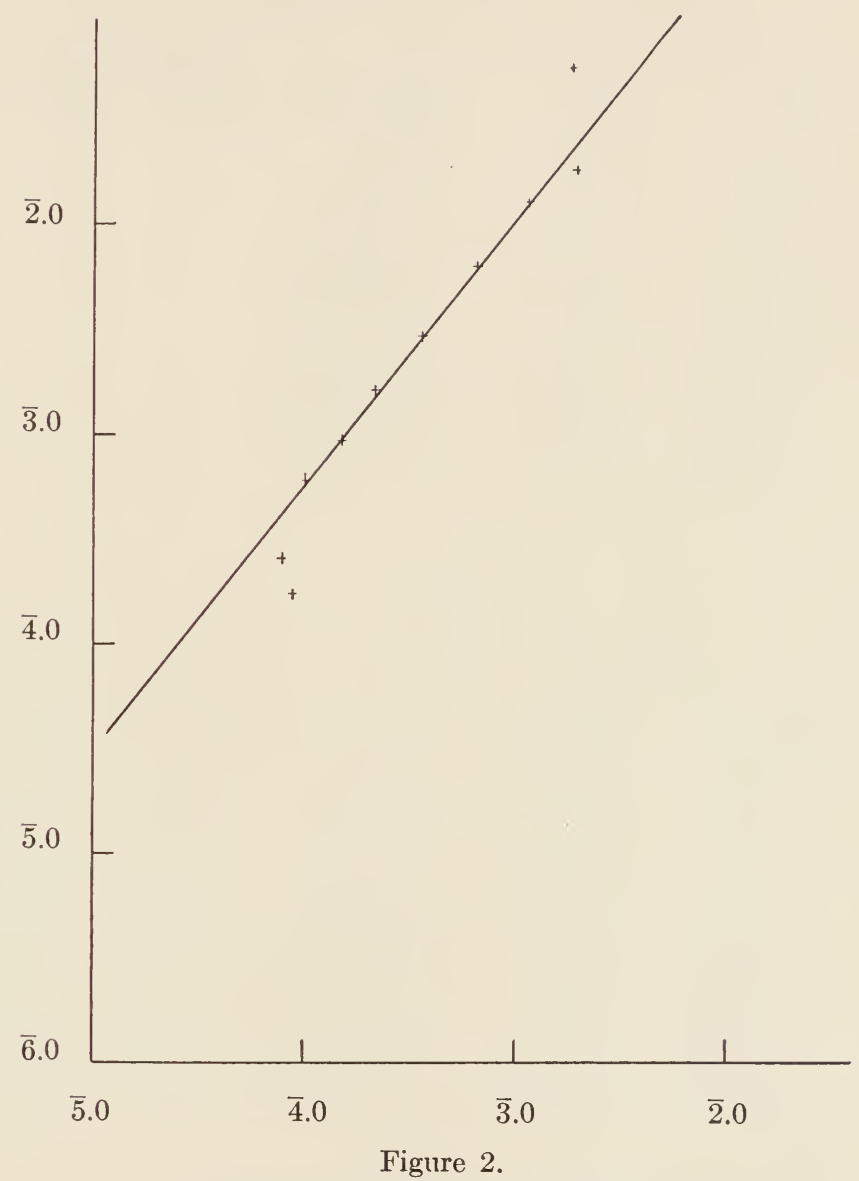

Sulfuric Acid and Calcium Silicate.

(See Table 2) 
TABLE 3

Oxalic Acid and Calcium Silicate

\begin{tabular}{|c|c|c|c|c|c|}
\hline Concentration & $\begin{array}{l}\mathrm{Ch}_{\mathrm{h}}, \mathrm{H} \text { ion } \\
\text { Oxalic } \\
\text { Acid }\end{array}$ & $\begin{array}{l}\text { Log. H ion } \\
\text { Oxalic } \\
\text { Acid }\end{array}$ & $\begin{array}{l}\text { H ion } \\
\text { Oxalic Acid } \\
\text { + Calcium Silicate }\end{array}$ & $\begin{array}{l}\text { Ca, Calcium } \\
\text { Mols. per } \\
\text { Liter }\end{array}$ & $\begin{array}{l}\text { Log. Calcium } \\
\text { Mols. per } \\
\text { Liter }\end{array}$ \\
\hline N 5 & 0.0218 & $\overline{2} .33846$ & 0.0347 & ......... & $\ldots \ldots$. \\
\hline N 25 & 0.0110 & $\overline{2} .04139$ & 0.0000192 & ........ & ......... \\
\hline N 50 & 0.00561 & $\overline{3} .74896$ & 0.00000175 & $\ldots \ldots \ldots$ & $\ldots \ldots .$. \\
\hline N 100 & 0.00347 & $\overline{3} .54033$ & 0.000000433 & ........ & $\ldots \ldots \ldots$ \\
\hline N 250 & 0.00169 & $\overline{3} .22789$ & 0.0000000941 & $\ldots \ldots .$. & $\ldots \ldots .$. \\
\hline N 500 & 0.00105 & $\overline{3} .02119$ & 0.0000000778 & $\ldots \ldots \ldots$ & $\ldots \ldots \ldots$ \\
\hline N 1,000 & 0.000554 & $\overline{4} .74351$ & 0.0000000719 & ........ & $\ldots \ldots \ldots$ \\
\hline N 2,000 & 0.000317 & $\overline{4} .50106$ & 0.0000000637 & $\ldots \ldots \ldots$ & $\ldots \ldots \ldots$ \\
\hline N 5,000 & 0.000132 & $\overline{4} .12057$ & 0.0000000544 & ........ & ......... \\
\hline N 10,000 & 0.0000785 & $\overline{5} .89487$ & 0.000000469 & $\ldots \ldots \ldots$ & ......... \\
\hline
\end{tabular}

TABLE 4

Phosphoric Acid and Calcium Silicate

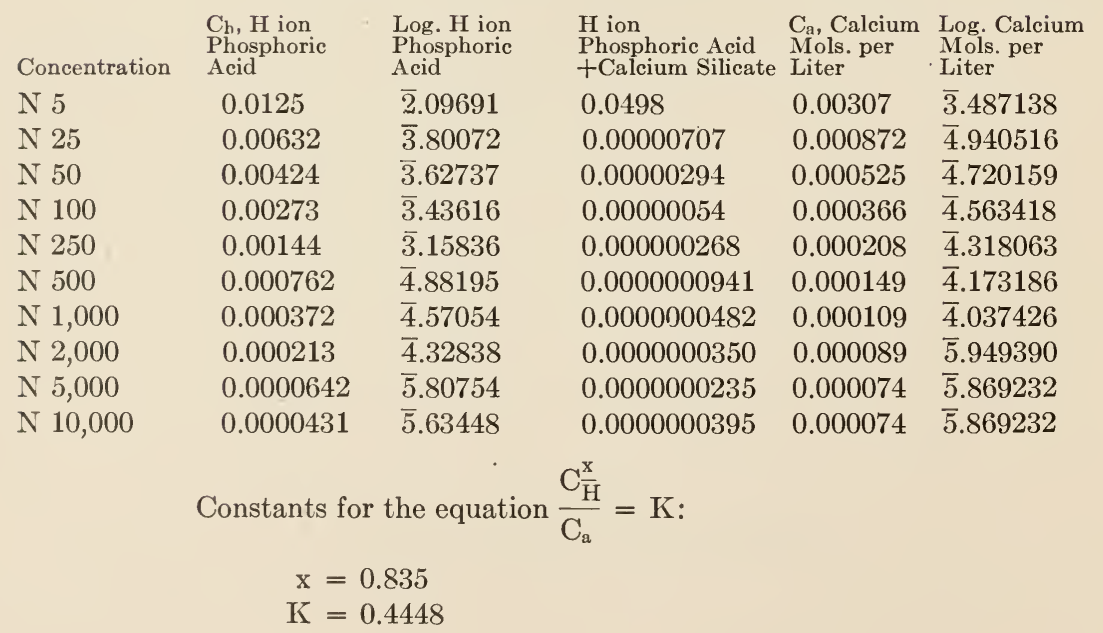




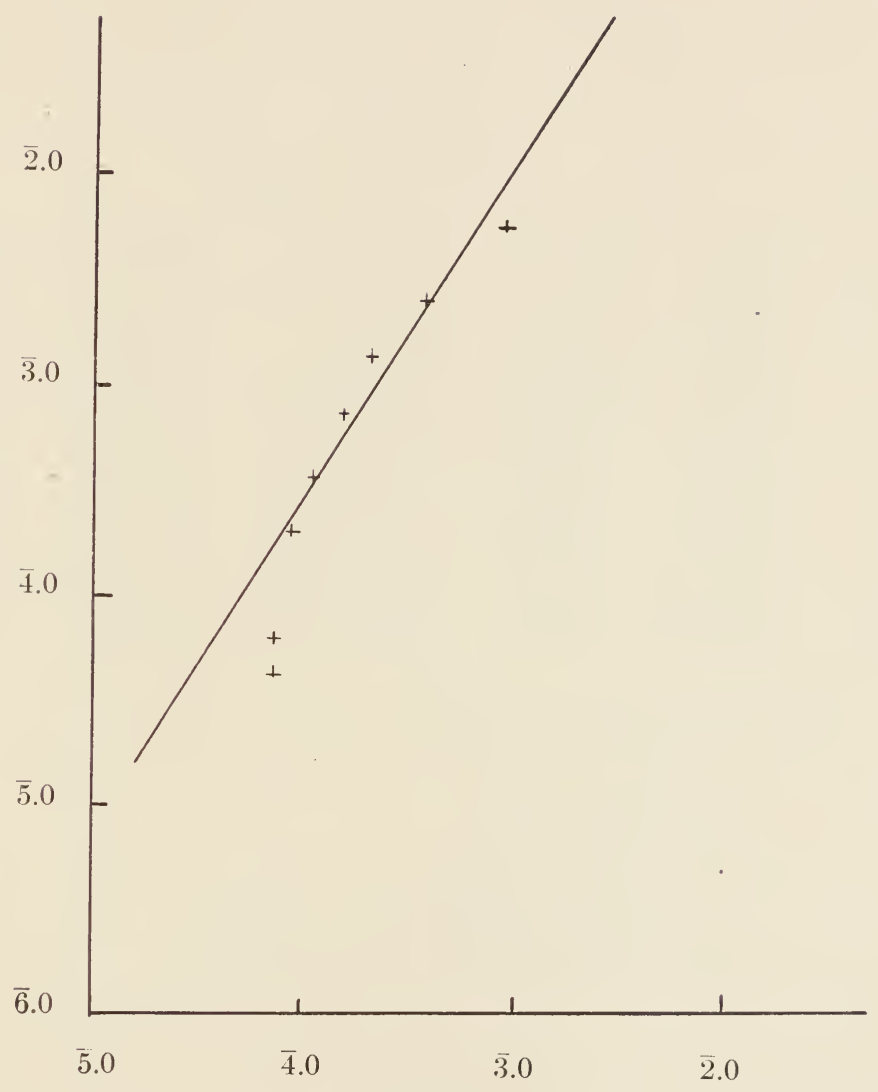

Figure 4.

Phosphoric Acid and Calcium Silicate.

(See Table 4) 
TABLE 5

Lactic Acid and Calcium Silicate

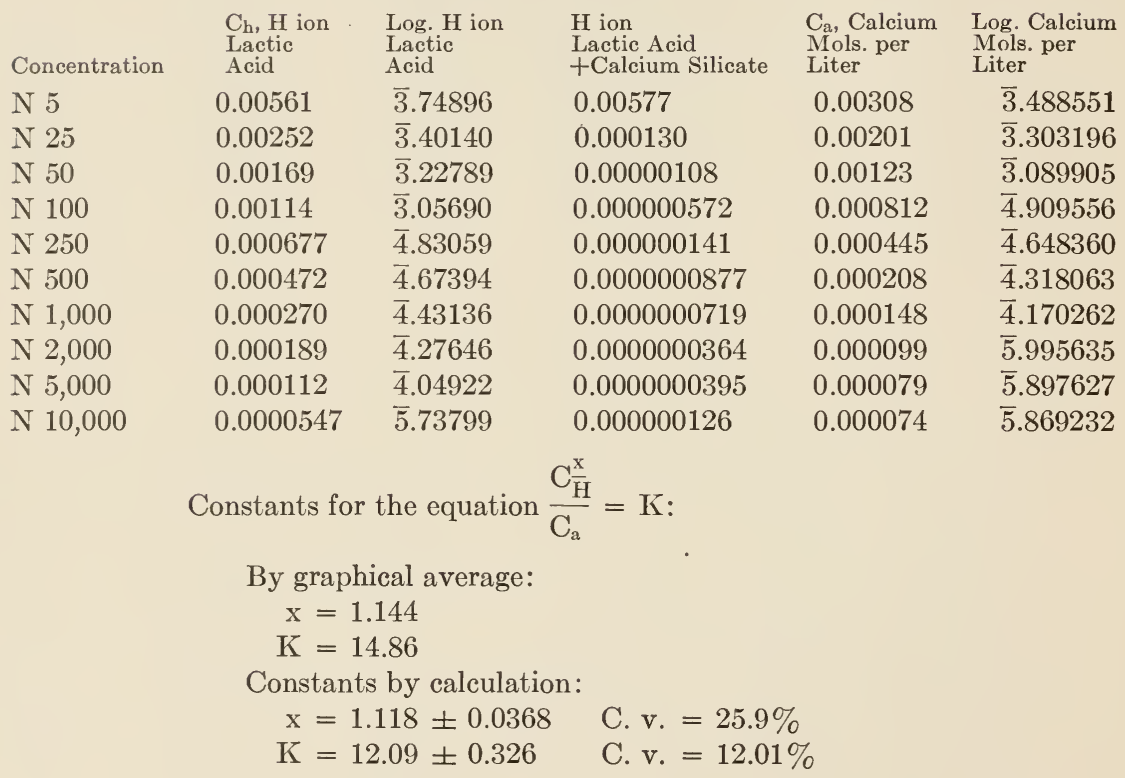




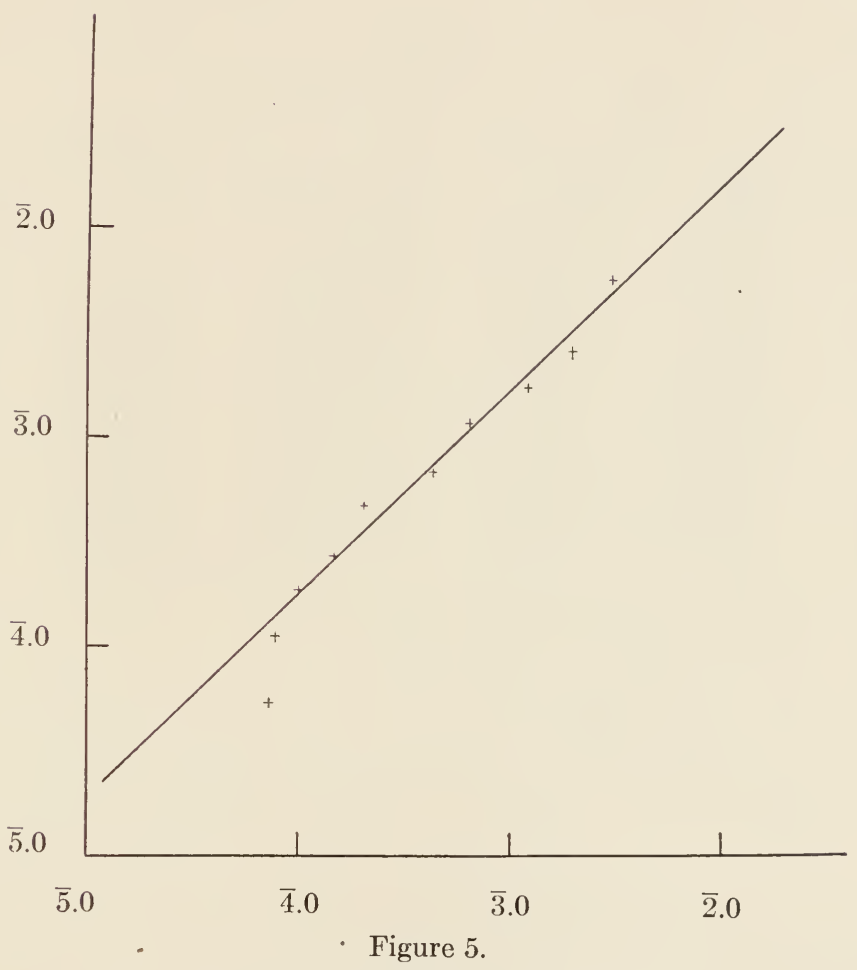

Lactic Acid and Calcium Silicate.

(See Table 5) 
TABLE 6

Formic Acid and Calcium Silicate

\begin{tabular}{|c|c|c|c|c|c|}
\hline Concentration & $\begin{array}{l}\mathrm{C}_{\mathrm{h}, \mathrm{H}} \mathrm{H} \text { ion } \\
\text { Formic } \\
\text { Acid }\end{array}$ & $\begin{array}{l}\text { Log. H ion } \\
\text { Formic } \\
\text { Aeid }\end{array}$ & $\begin{array}{l}\text { H ion } \\
\text { Formic Acid } \\
\text { +Calcium Silicate }\end{array}$ & $\begin{array}{l}\mathrm{C}_{\mathrm{a}, \text { al Calcium }} \\
\text { Mlols. per } \\
\text { Liter }\end{array}$ & $\begin{array}{l}\text { Log. Calcium } \\
\text { Mols. per } \\
\text { Liter. }\end{array}$ \\
\hline N 5 & 0.00518 & $\overline{3} .71433$ & 0.00577 & & \\
\hline N 25 & 0.00233 & $\overline{3} .36736$ & 0.0000635 & & \\
\hline N 50 & 0.00156 & $\overline{3} .19312$ & 0.000000620 & 0.00119 & $\overline{3} .075547$ \\
\hline N 100 & 0.0010 & $\overline{3} .00000$ & 0.000000327 & 0.000694 & $\overline{4} .841359$ \\
\hline N 250 & 0.000762 & $\overline{4} .88195$ & 0.0000000719 & 0.000365 & $\overline{4} .563481$ \\
\hline N 500 & 0.000472 & $\overline{4} .67394$ & 0.0000000522 & 0.000208 & $\overline{4} .318063$ \\
\hline N 1,000 & 0.000343 & $\overline{4} .53529$ & 0.0000000350 & 0.000138 & $\overline{4} .139879$ \\
\hline $\mathrm{N} 2,000$ & 0.000181 & $\overline{4} .25768$ & 0.0000000276 & 0.000119 & $\overline{4} .075547$ \\
\hline N 5,000 & 0.0000753 & $\overline{5} .87679$ & 0.0000000245 & 0.000099 & $\overline{5} .995635$ \\
\hline N 10,000 & 0.0000398 & $\overline{5} .59988$ & 0.0000000719 & 0.0000248 & $\overline{5} .394452$ \\
\hline \multicolumn{6}{|c|}{$\frac{\mathrm{C}_{\mathrm{H}}^{\mathrm{x}}}{\mathrm{C}_{\mathrm{a}}}=\mathrm{K}:$} \\
\hline
\end{tabular}




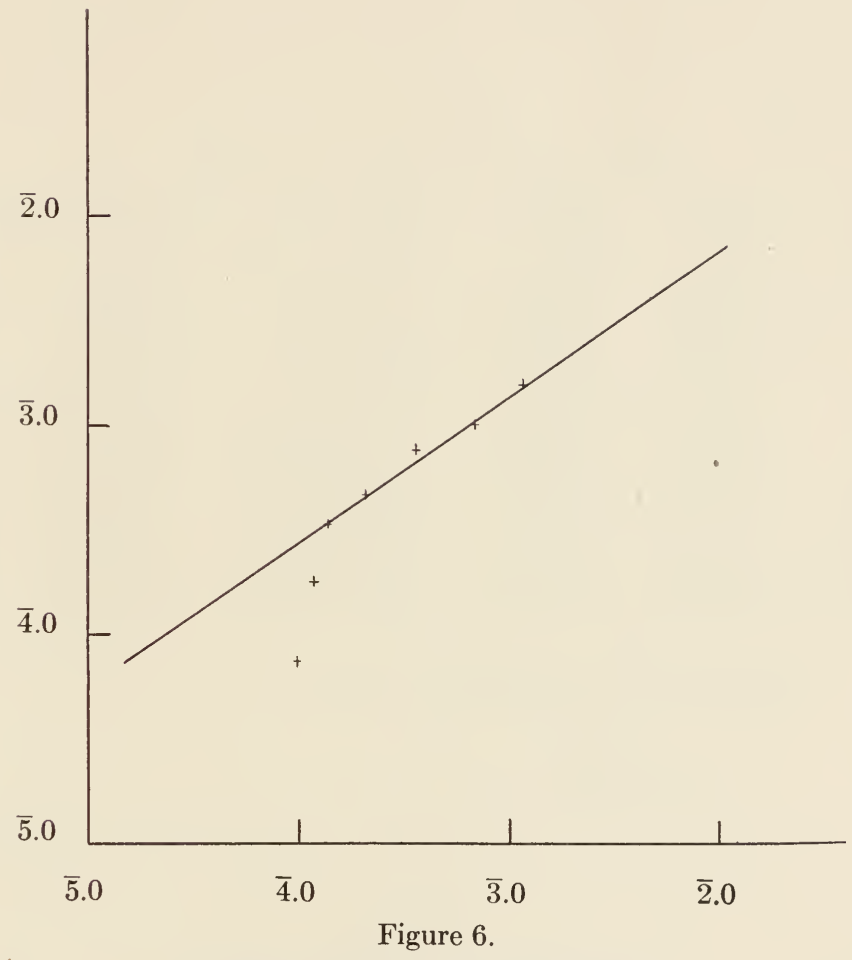

Formic Acid and Calcium Silicate.

(See Table 6) 
TABLE 7

Acetic Acid and Calcium Silicate

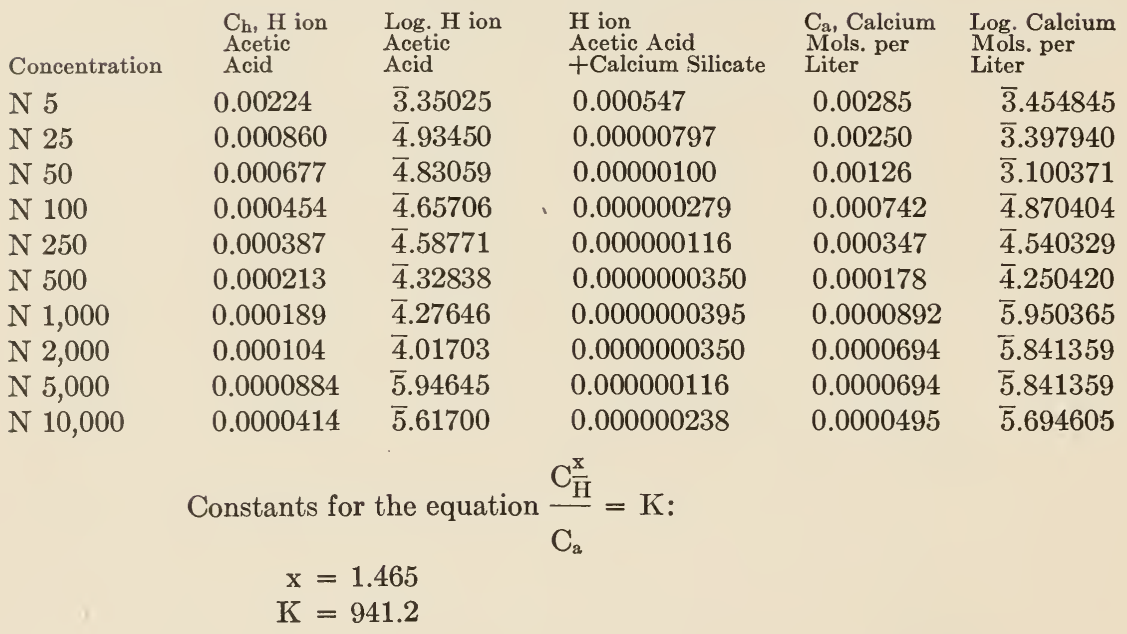




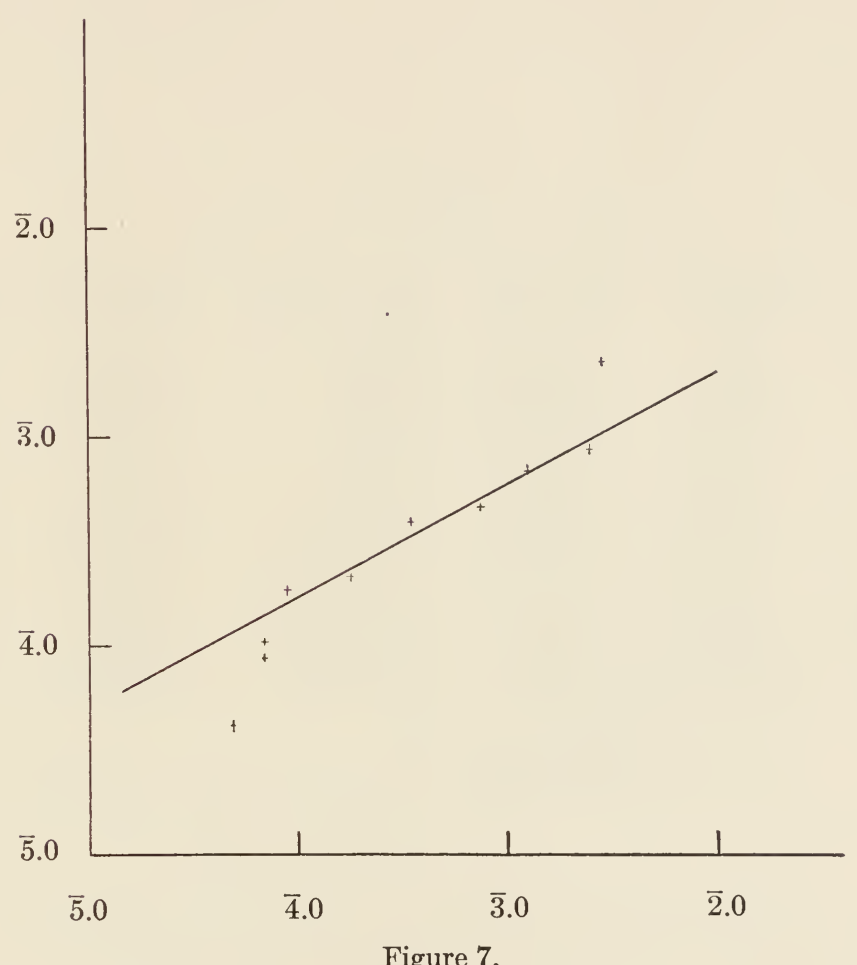

Acetic Acid and Calcium Silicate.

(See Table 7) 
TABLE 8

Hydrochloric Acid and Orthoclase

\begin{tabular}{|c|c|c|c|c|c|}
\hline Concentration & $\begin{array}{l}\mathrm{C}_{h}, \mathrm{H} \text { ion } \\
\text { Hydrochloric } \\
\text { Acid }\end{array}$ & $\begin{array}{l}\text { Log. H ion } \\
\text { Hydrochloric } \\
\text { Acid }\end{array}$ & $\begin{array}{l}\text { H ion } \\
\text { Hydrochloric Acid } \\
\text { +Orthoclase }\end{array}$ & $\begin{array}{l}\text { Ca, Calcium } \\
\text { Mols. per } \\
\text { Liter }\end{array}$ & $\begin{array}{l}\text { Log. Calcium } \\
\text { Mols. per } \\
\text { Liter }\end{array}$ \\
\hline N 5 & 0.0882 & $\overline{2} .94547$ & 0.0615 & 0.00159 & $\overline{3} .201397$ \\
\hline N 25 & 0.0218 & $\overline{2} .33846$ & 0.0218 & 0.001449 & $\overline{3} .159567$ \\
\hline N 50 & 00135 & $\overline{2} .13003$ & 0.00836 & 0.001045 & $\overline{3} .019116$ \\
\hline N 100 & 0.00685 & $\overline{3} .83569$ & 0.00296 & 0.00094 & $\overline{4} .973128$ \\
\hline N 250 & 0.00321 & $\overline{3} .50651$ & 0.000554 & 0.000685 & $\overline{4} .835691$ \\
\hline N 500 & 0.00114 & $\overline{3} .05690$ & 0.0000784 & 0.000565 & $\overline{4} .752048$ \\
\hline N 1,000 & 0.000677 & $\overline{4} .83059$ & 0.000000935 & 0.00056 & $\overline{4} .748188$ \\
\hline N 2,000 & 0.000281 & $\overline{4} .44871$ & 0.00000110 & 0.00040 & $\overline{4} .602060$ \\
\hline N 5,000 & 0.0000326 & $\overline{5} .51322$ & 0.000000261 & 0.00038 & $\overline{4} .579784$ \\
\hline N 10,000 & 0.00000192 & $\overline{6} .28330$ & 0.00000010 & 0.000336 & $\overline{4} .526339$ \\
\hline
\end{tabular}




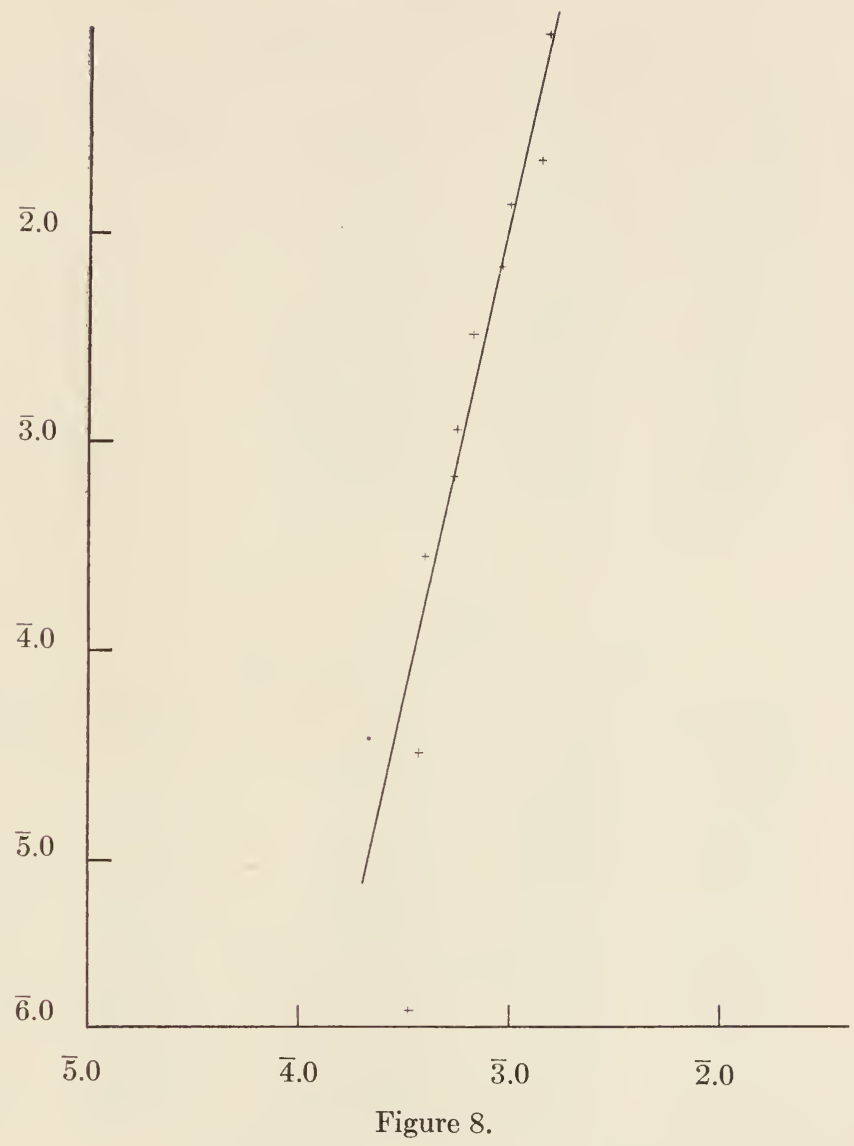

Hydrochloric Acid and Orthoclase.

(See Table 8) 
TABLE 9

Concentration
N 5
N 25
N 50
N 100
N 250
N 500
N 1,000
N 2,000
N 5,000
N 10,000

$\begin{array}{ll}\begin{array}{l}\mathrm{C}_{\mathrm{h}}, \mathrm{H} \text { ion } \\ \text { Oxalic } \\ \text { Acid }\end{array} & \begin{array}{l}\text { Log. } \mathrm{H} \text { ion } \\ \text { Oxalic } \\ \text { Acid }\end{array} \\ 0.0218 & \overline{2} .33846 \\ 0.0110 & \overline{2} .04139 \\ 0.00561 & \overline{3} .74896 \\ 0.00347 & \overline{3} .54033 \\ 0.00169 & \overline{3} .22789 \\ 0.00105 & \overline{3} .02119 \\ 0.000554 & \overline{4} .74351 \\ 0.000317 & \overline{4} .56937 \\ 0.000132 & \overline{4} .12057 \\ 0.0000785 & \overline{5} .89487\end{array}$

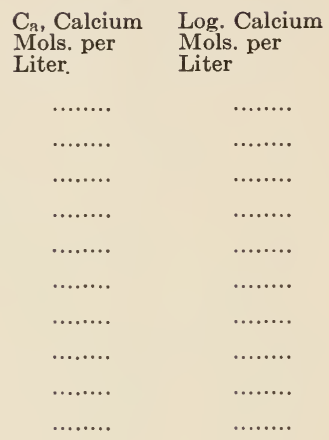

TABLE 10

Lactic ACID AND ORthoclase

\begin{tabular}{|c|c|c|c|c|c|}
\hline Concentration & $\begin{array}{l}\mathrm{Ch}_{\mathrm{h}}, \mathrm{H} \text { ion } \\
\text { Lactic } \\
\text { Acid }\end{array}$ & $\begin{array}{l}\text { Log. H ion } \\
\text { Lactic } \\
\text { Acid }\end{array}$ & $\begin{array}{l}\mathrm{H} \text { ion } \\
\text { Lactic Acid } \\
\text { +Orthoclase }\end{array}$ & $\begin{array}{l}\text { Ca, Calcium } \\
\text { Mols. per } \\
\text { Liter }\end{array}$ & $\begin{array}{l}\text { Log. Calcium } \\
\text { Mols. per } \\
\text { Liter }\end{array}$ \\
\hline N 5 & 0.00561 & $\overline{3} .74896$ & 0.00441 & 0.001190 & $\overline{3} .075547$ \\
\hline N 25 & 0.00252 & $\overline{3} .40140$ & 0.00123 & 0.00094 & $\overline{4} .973128$ \\
\hline N 50 & 0.00169 & $\overline{3} .22789$ & 0.000650 & 0.00077 & $\overline{4} .886491$ \\
\hline N 100 & 0.00114 & $\overline{3} .05690$ & 0.000372 & 0.000495 & $\overline{4} .694605$ \\
\hline N 250 & 0.000677 & $\overline{4} .83059$ & 0.000181 & 0.00073 & $\overline{4} .863323$ \\
\hline N 500 & 0.000472 & $\overline{4} .67394$ & 0.0000414 & 0.000495 & $\overline{4} .694605$ \\
\hline N 1,000 & 0.000270 & $\overline{4} .43136$ & 0.00000322 & 0.000465 & $\overline{4} .667453$ \\
\hline N 2,000 & 0.000189 & $\overline{4} .27646$ & 0.00000217 & 0.000475 & $\overline{4} .676694$ \\
\hline N 5,000 & 0.000110 & $\overline{4} .04139$ & 0.000000282 & 0.000366 & $\overline{4} .563481$ \\
\hline N 10,000 & 0.0000547 & $\overline{5} .73799$ & 0.000000261 & 0.000238 & $\overline{4} .376577$ \\
\hline \multicolumn{6}{|c|}{$\begin{array}{l}\text { Constants for Calcium: } \\
\qquad \begin{aligned} \mathrm{x}=0.324 \\
\mathrm{~K}=0.00002661\end{aligned}\end{array}$} \\
\hline
\end{tabular}

\begin{tabular}{|c|c|c|}
\hline $\begin{array}{l}\text { H ion } \\
\text { Oxalic Acid } \\
\text { +Orthoclase }\end{array}$ & $\begin{array}{l}\mathrm{C}_{\mathrm{f}} \text {, Calcium } \\
\text { Mols. per } \\
\text { Liter. }\end{array}$ & $\begin{array}{l}\text { Log. Calcium } \\
\text { Mols. per } \\
\text { Liter }\end{array}$ \\
\hline 0.0245 & $\ldots \ldots .$. & $\ldots \ldots \ldots$ \\
\hline 0.00905 & $\ldots \ldots \ldots$ & ........ \\
\hline 0.00376 & $\ldots \ldots \ldots$ & $\ldots \ldots \ldots$ \\
\hline 0.000650 & $\ldots \ldots \ldots$ & ........ \\
\hline 0.00000564 & ........ & $\ldots \ldots \ldots$ \\
\hline 0.000000735 & $\ldots \ldots \ldots$ & $\ldots \ldots \ldots$ \\
\hline 0.000000438 & ......... & $\ldots \ldots \ldots$ \\
\hline 0.000000294 & $\ldots \ldots \ldots$ & $\ldots \ldots \ldots$ \\
\hline 0.00000294 & $\ldots \ldots \ldots$ & $\ldots \ldots \ldots$ \\
\hline 0.00000294 & ........ & ......... \\
\hline
\end{tabular}
ter per

$0.000677 \quad \overline{4} .83059 \quad 0.000181$

$\begin{array}{lll}0.000472 & \overline{4} .67394 & 0.0000414\end{array}$

0.000270

0.00000322

$\overline{4} .694605$

$\overline{4} .667453$

$\overline{4} .676694$

$0.000110 \quad \overline{4} .04139$

0.000000282

$\overline{4} .563481$

Constants for Calcium:

$\mathrm{K}=0.00002661$ 


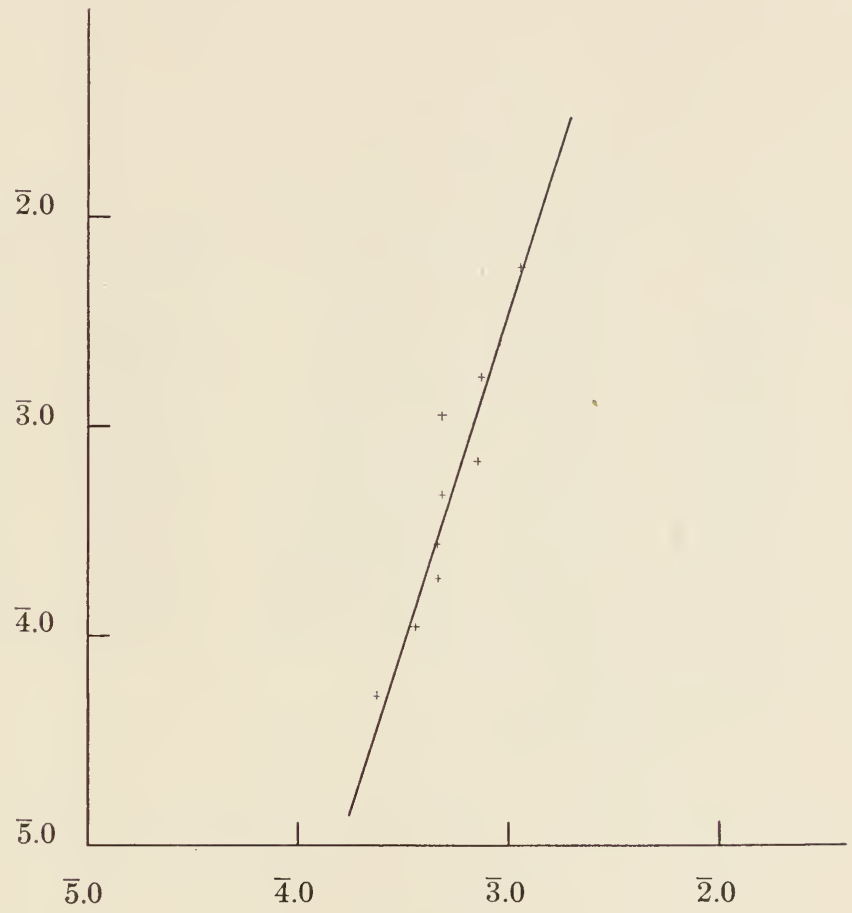

Figure 10.

Lactic Acid and Orthoclase.

(See Table 10) 


\section{TABLE 11}

Formic Acid and Orthoclase

\begin{tabular}{|c|c|c|c|c|c|}
\hline Concentration & $\begin{array}{l}\mathrm{Ch}_{\mathrm{h}}, \mathrm{H} \text { ion } \\
\text { Formic } \\
\text { Acid }\end{array}$ & $\begin{array}{l}\text { Log. H ion } \\
\text { Formic } \\
\text { Acid }\end{array}$ & $\begin{array}{l}\mathrm{H} \text { ion } \\
\text { Formic Acid } \\
\text { +Orthoclase }\end{array}$ & $\begin{array}{l}\mathrm{C}_{a} \text {, Calcium } \\
\text { Mols. per } \\
\text { Liter }\end{array}$ & $\begin{array}{l}\text { Log. Calcium } \\
\text { Mols. per } \\
\text { Liter }\end{array}$ \\
\hline N 5 & 0.00518 & $\overline{3} .71433$ & 0.00296 & 0.000862 & $\overline{4} .935507$ \\
\hline N 25 & 0.00233 & $\overline{3} .36736$ & 0.000677 & 0.000812 & $\overline{4} .909556$ \\
\hline N 50 & 0.00156 & $\overline{3} .19312$ & 0.000270 & 0.000723 & $\overline{4} .859138$ \\
\hline N 100 & 0.0010 & $\overline{3} .00000$ & 0.0000957 & 0.000713 & $\overline{4} .853090$ \\
\hline N 250 & 0.000762 & $\overline{4} .88195$ & 0.0000153 & 0.000605 & $\overline{4} .781755$ \\
\hline N 500 & 0.000472 & $\overline{4} .67394$ & 0.00000579 & 0.000535 & $\overline{4} .728354$ \\
\hline N 1,000 & 0.000343 & $\overline{4} .53529$ & 0.000000197 & 0.000535 & $\overline{4} .728354$ \\
\hline N 2,000 & 0.000181 & $\overline{4} .25768$ & 0.000000197 & 0.000495 & $\overline{4} .694605$ \\
\hline & 00000753 & $\overline{5} .87679$ & 0.000000205 & 0.000475 & $\overline{4} .676694$ \\
\hline 10,000 & 0.0000398 & $\overline{5} .59988$ & 0.0000000923 & 0.000426 & $\overline{4} .629410$ \\
\hline
\end{tabular}

Constants for Calcium:

$$
\begin{aligned}
\mathrm{x} & =0.142 \\
\mathrm{~K} & =0.000001427
\end{aligned}
$$




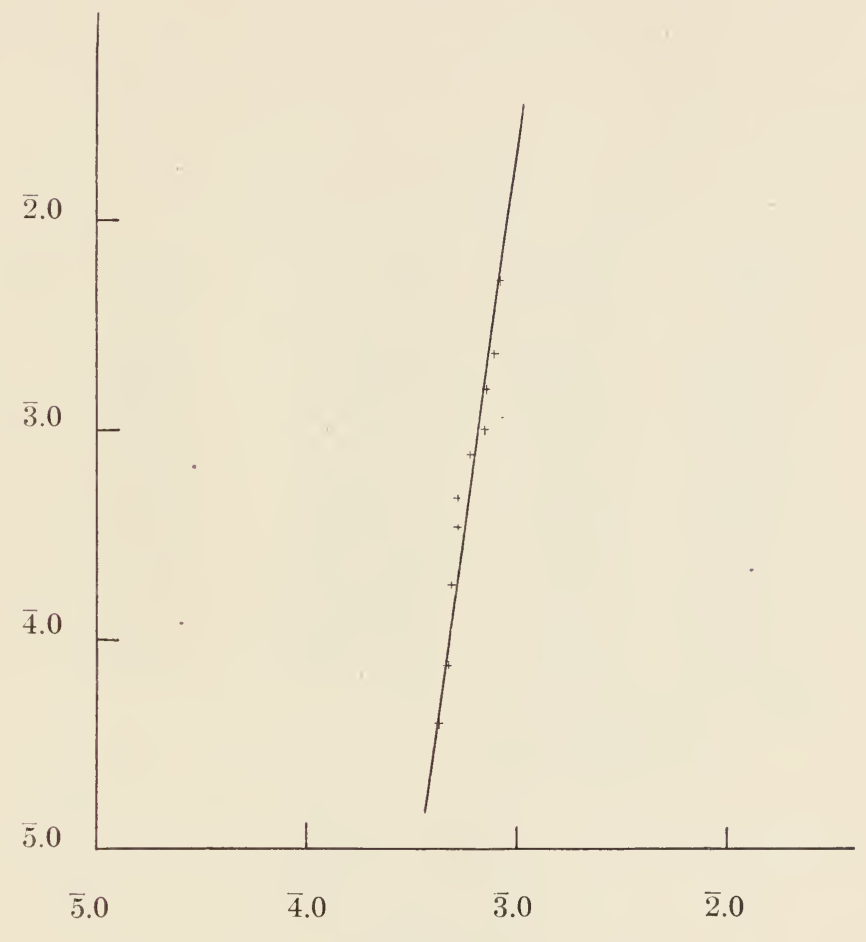

Figure 11.

Formic Acid and Orthoclase.

(See Table 11) 
TABLE 12

Acetic Acid and Orthoclase.

$\begin{array}{llllll}\text { Concentration } & \begin{array}{l}\mathrm{C}_{h}, \mathrm{H} \text { ion } \\ \text { Acetic } \\ \text { Acid }\end{array} & \begin{array}{l}\text { Log. H ion } \\ \text { Acetic } \\ \text { Acid }\end{array} & \begin{array}{l}\mathrm{H} \text { ion } \\ \text { Acetic Acid } \\ \text { +Orthoclase }\end{array} & \begin{array}{l}\mathrm{C} \text {, Calcium } \\ \text { Mols. per } \\ \text { Liter }\end{array} & \begin{array}{l}\text { Log. Calcium } \\ \text { Mols. per } \\ \text { Liter }\end{array} \\ \text { N 5 } & 0.00224 & \overline{3} .35025 & 0.000472 & 0.000074 & \overline{4} .869232 \\ \text { N 25 } & 0.000860 & \overline{4} .93450 & 0.000132 & 0.000058 & \overline{4} .763428 \\ \text { N } 50 & 0.000677 & \overline{4} .83059 & 0.0000696 & 0.00062 & \overline{4} .792392 \\ \text { N } 100 & 0.000454 & \overline{4} .65706 & 0.0000431 & 0.00065 & \overline{4} .812913 \\ \text { N 250 } & 0.000387 & \overline{4} .58771 & 0.0000179 & 0.00051 & \overline{4} .707570 \\ \text { N } 500 & 0.000213 & \overline{4} .32838 & 0.00000745 & 0.00048 & \overline{4} .681241 \\ \text { N } 1,000 & 0.000189 & \overline{4} .27646 & 0.00000225 & 0.00043 & \overline{4} .633468 \\ \text { N 2,000 } & 0.000104 & \overline{4} 01703 & 0.000000627 & 0.00039 & \overline{4} .591065 \\ \text { N 5,000 } & 0.0000884 & \overline{5} .94645 & 0.000000438 & 0.00033 & \overline{4} .518514 \\ \text { N 10,000 } & 0.0000414 & \overline{5} .61700 & 0.000000261 & 0.00029 & \overline{4} .462398\end{array}$

Constants for Calcium:

$$
\begin{aligned}
\mathrm{x} & =0.235 \\
\mathrm{~K} & =0.000006966
\end{aligned}
$$




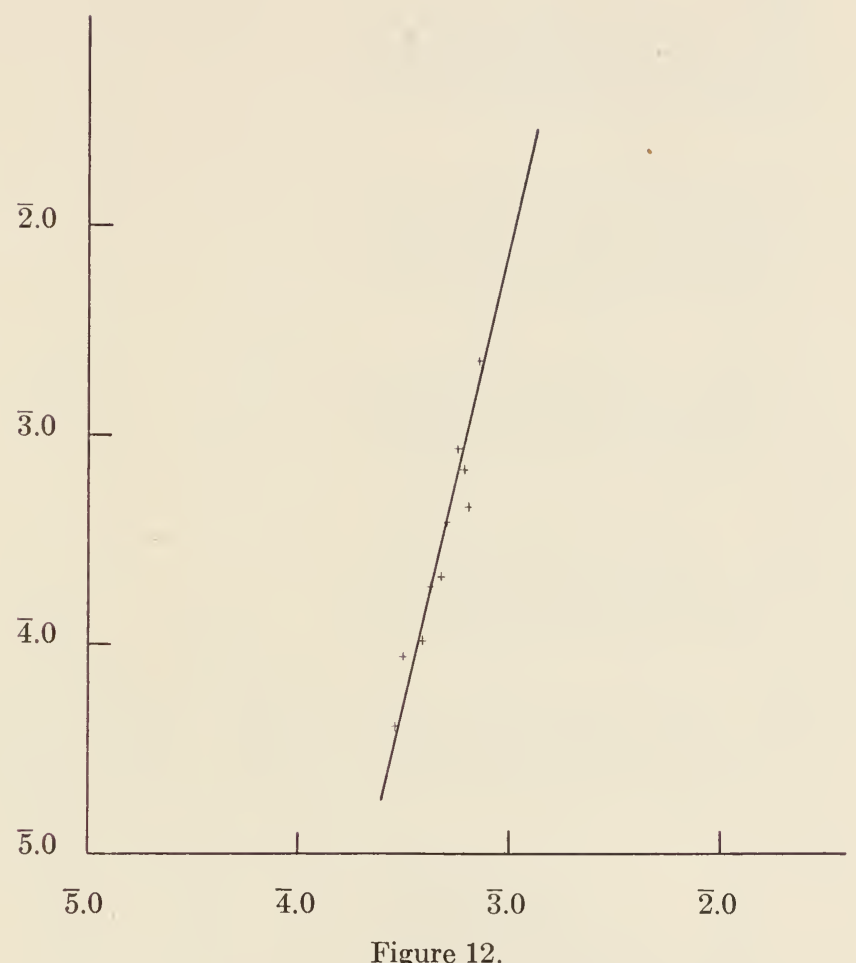

Acetic Acid and Orthoclase.

(See Table 12) 


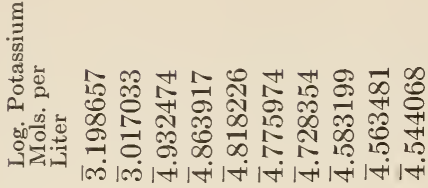

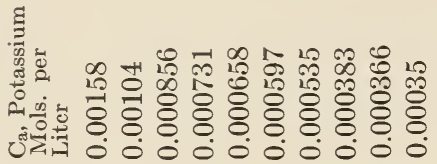

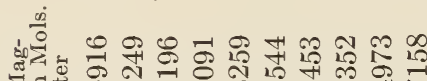

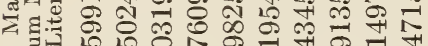

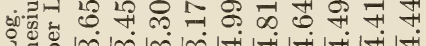

क्ष

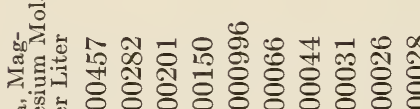

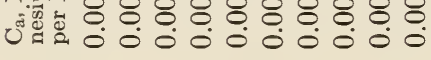

齐

œ

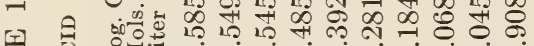

य

屆

要

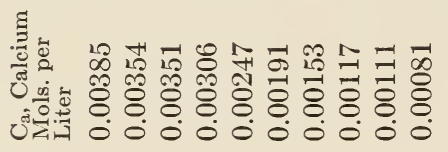

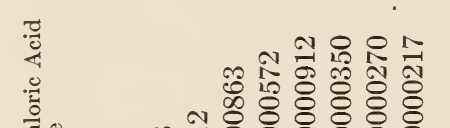

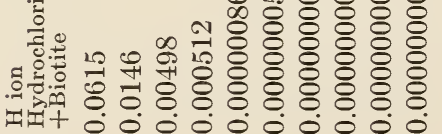

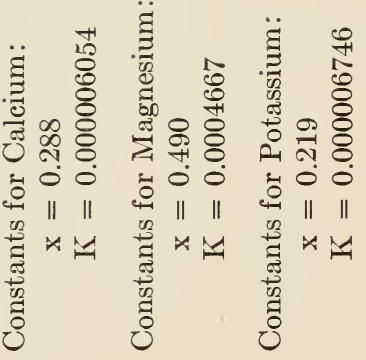

范苛 구유

at: $\begin{aligned} & 10 \\ & 0\end{aligned}$

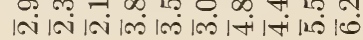

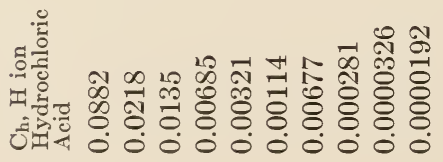

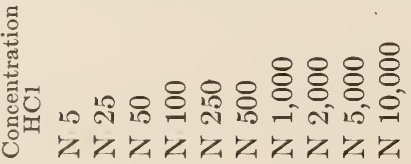




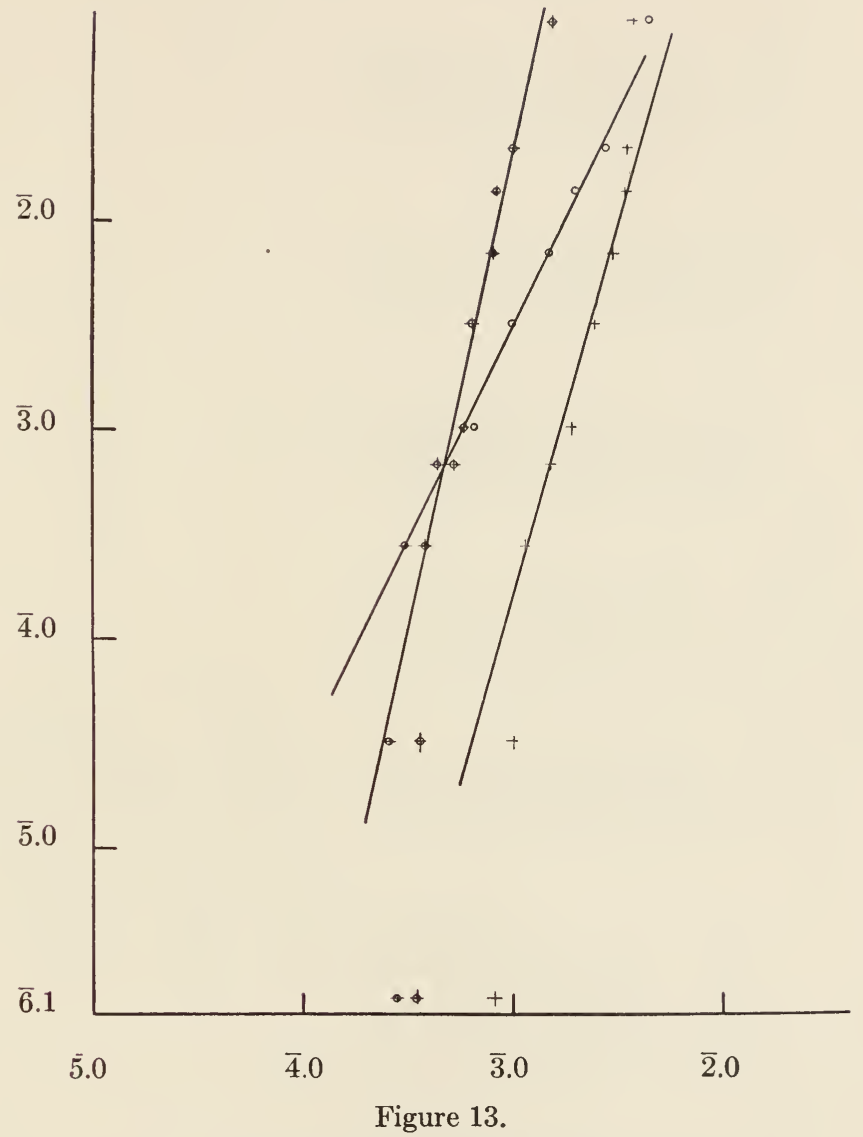

Hydrochloric Acid and Biotite.

(See Table 13) 
हี

แै vion. 卯

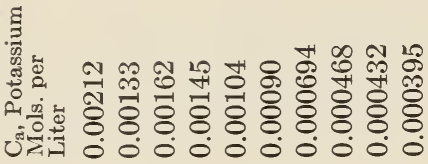
สำ ai.

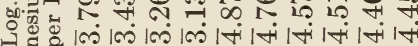

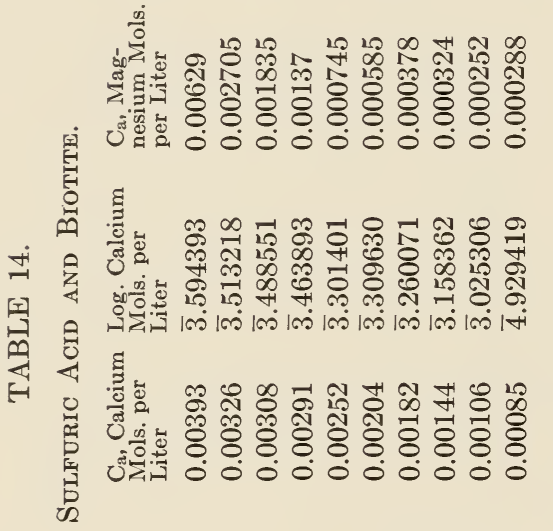

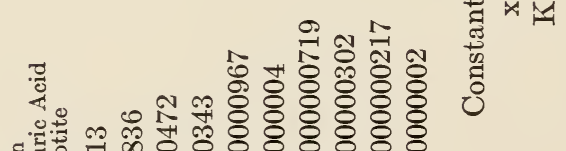

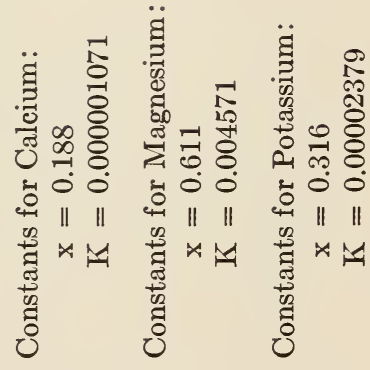

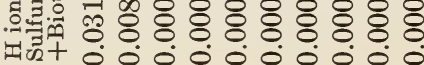
.ำ

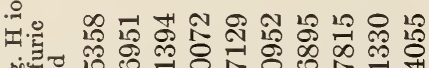
mid귱 in

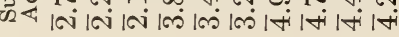

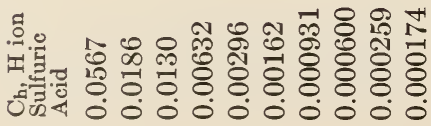

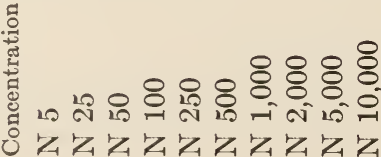




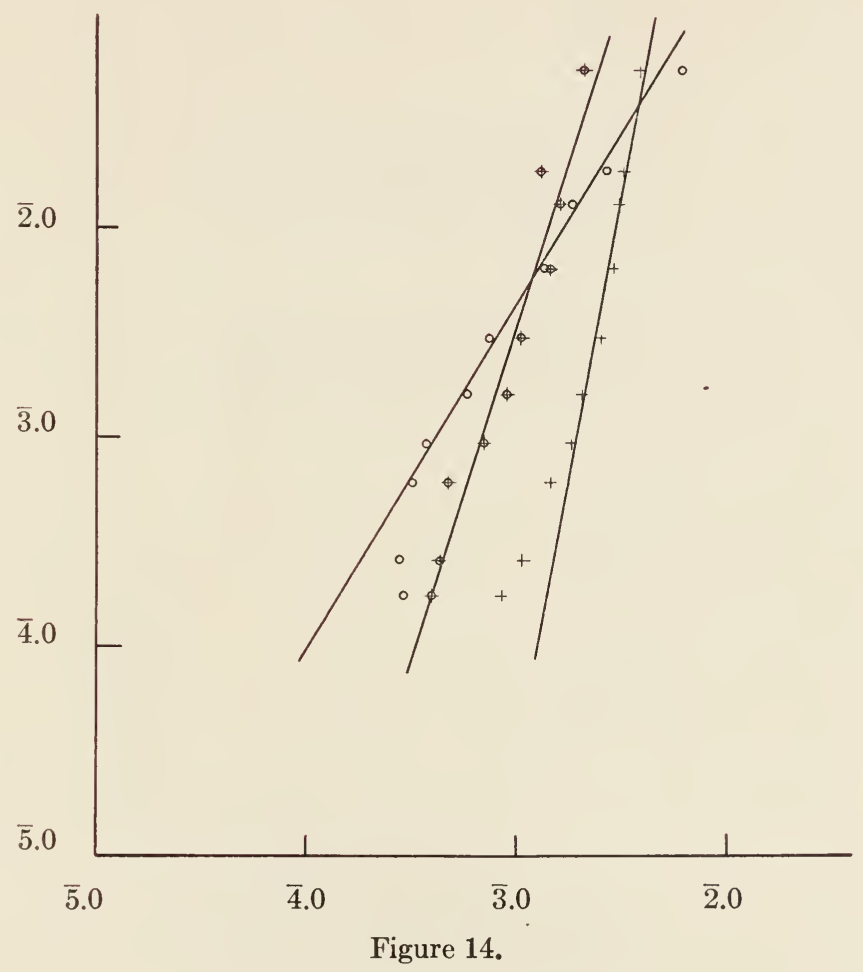

Sulfuric Acid and Biotite.

(See Table 14) 
蛋

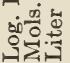

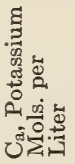

究 踏

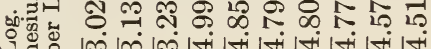

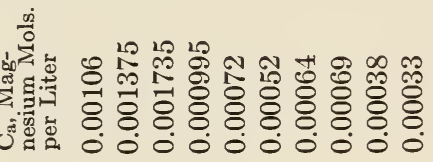

12

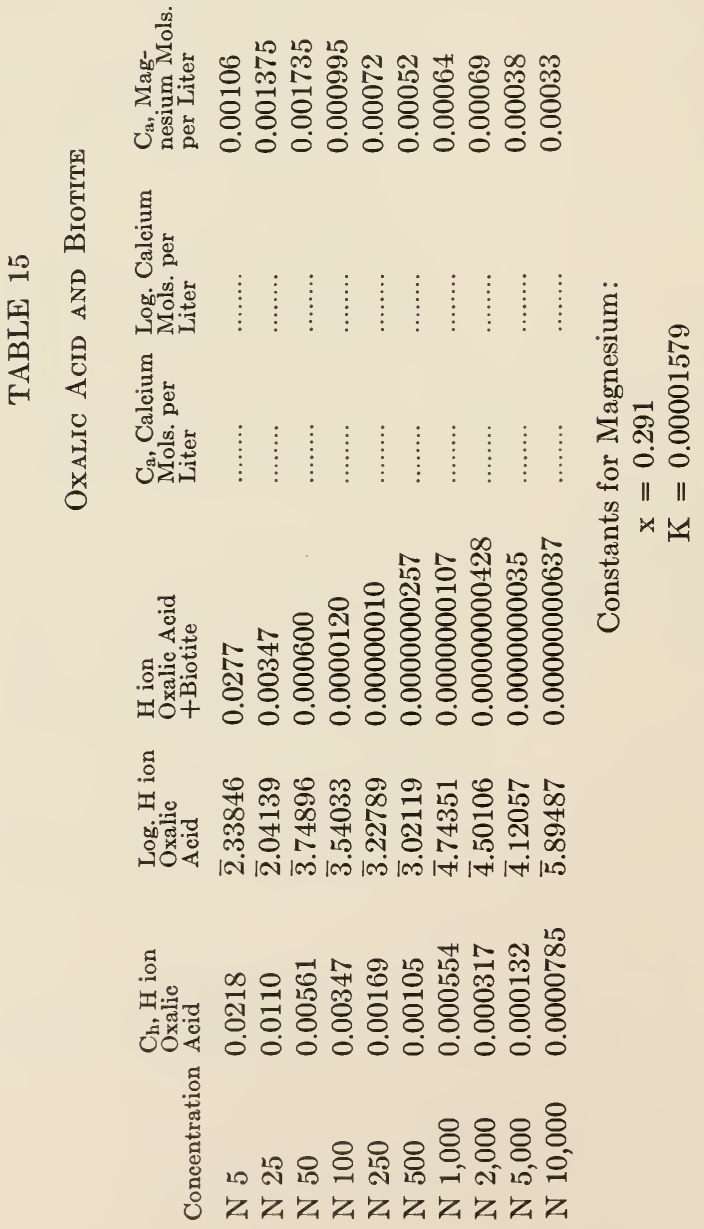




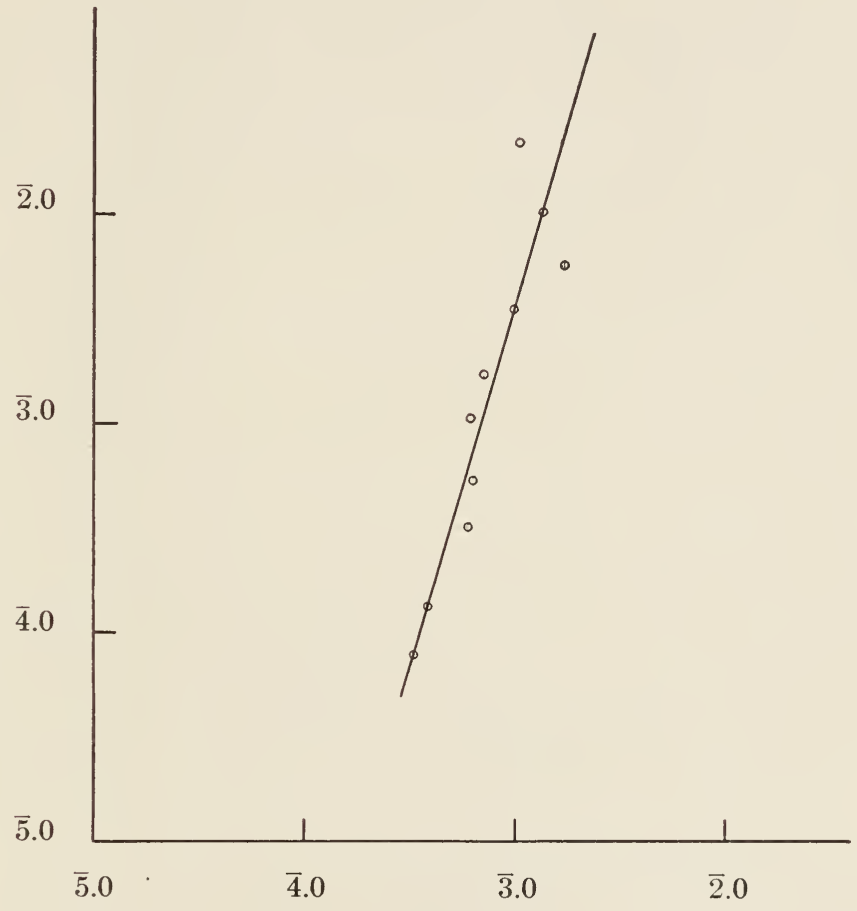

Figure 15.

Oxalic Acid and Biotite.

(See Table 15) 
疍

\%

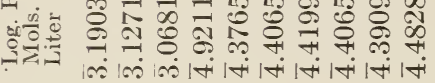

ह

๑ 15

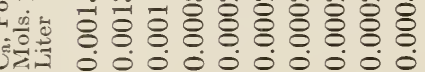

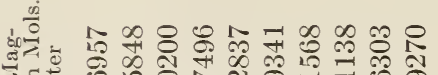

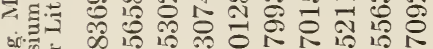

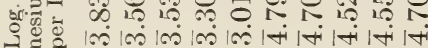

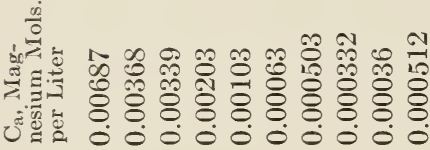

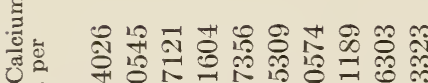
หiำ

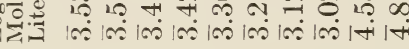

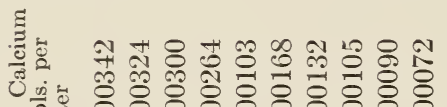

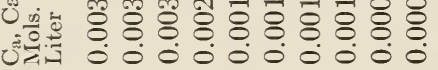
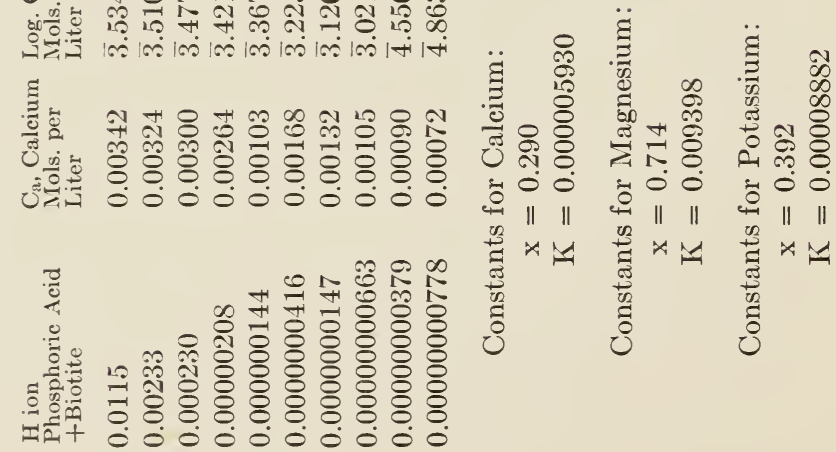

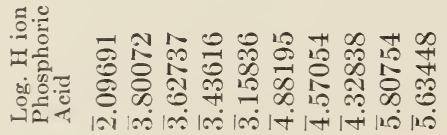

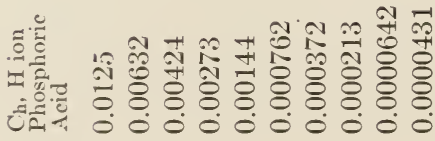

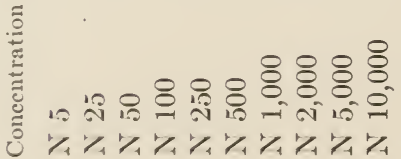




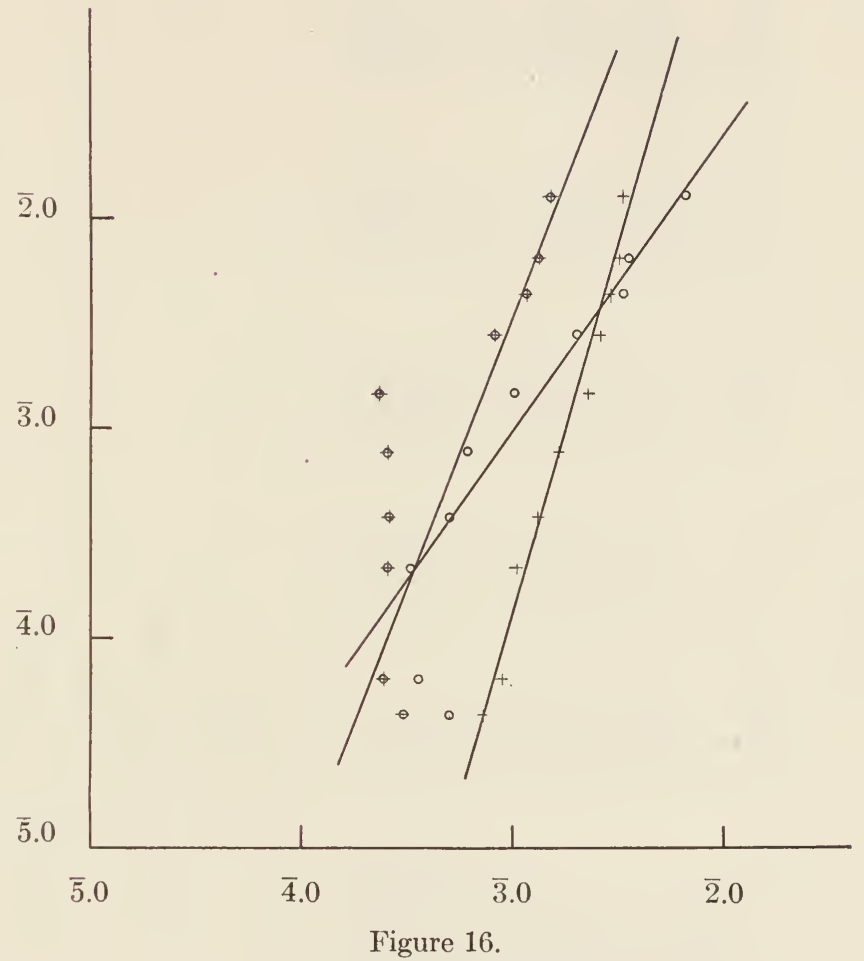

Phosphoric Acid and Biotite.

(See Table 16) 
䄈

然

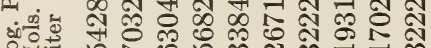

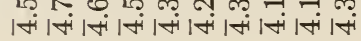

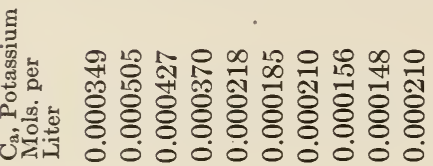

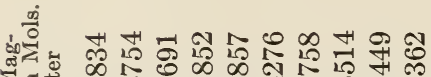

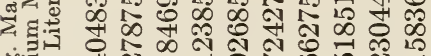

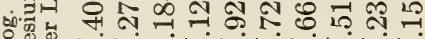

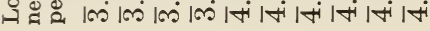

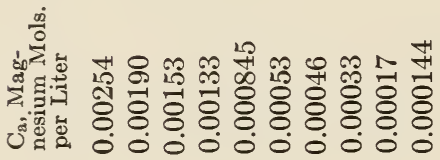

뱄

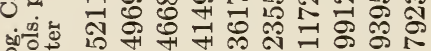

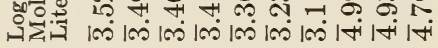

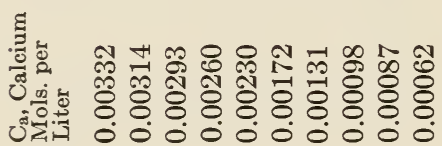

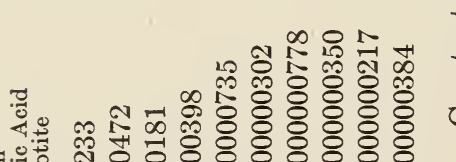

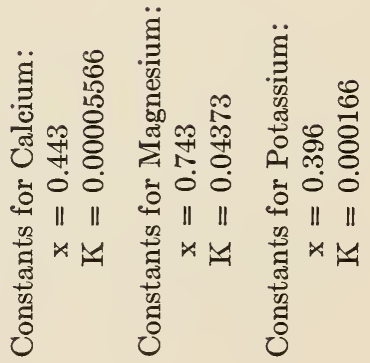

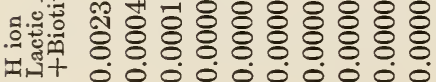
.

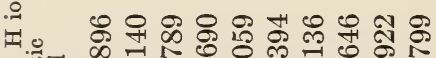

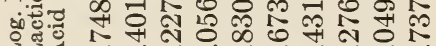

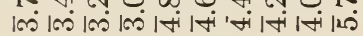

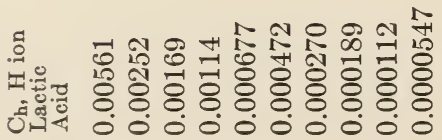

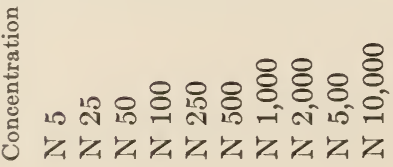




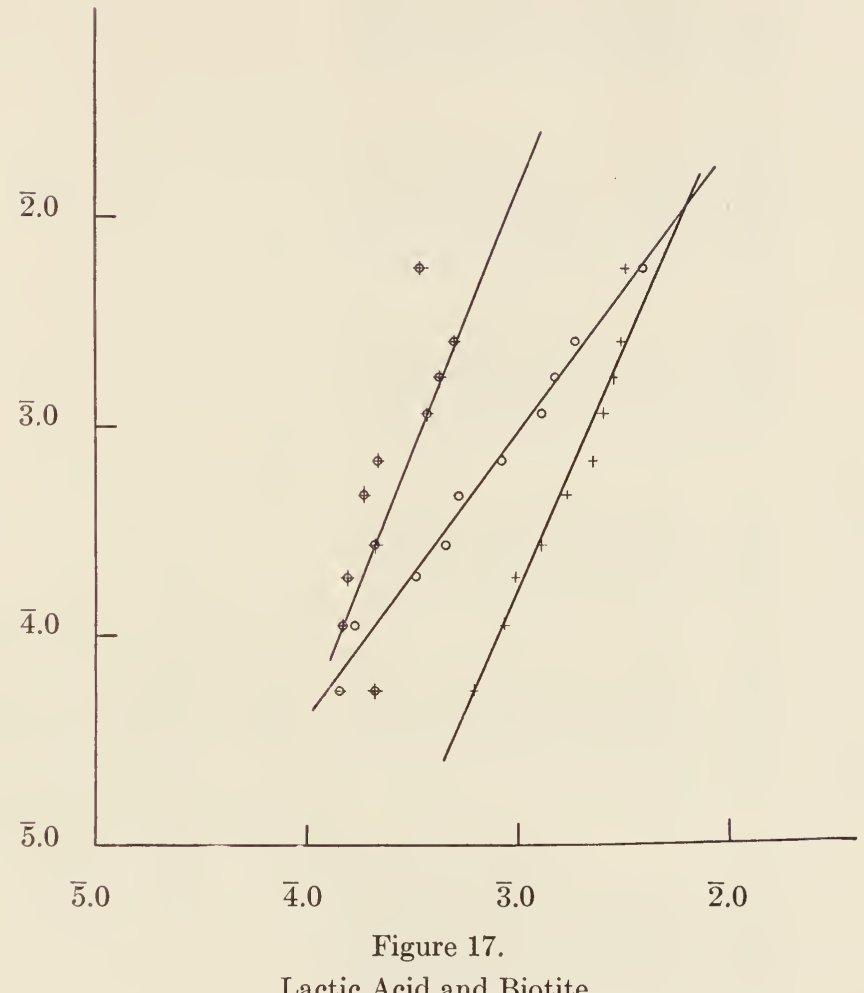

Lactic Acid and Biotite.

(See Table 17) 


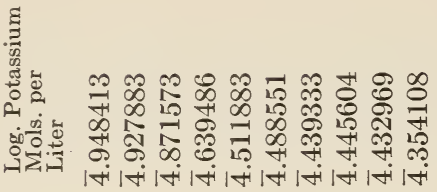

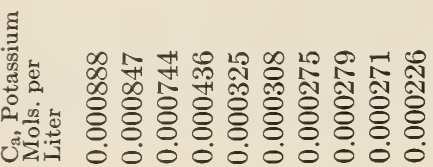

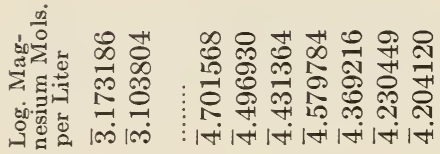

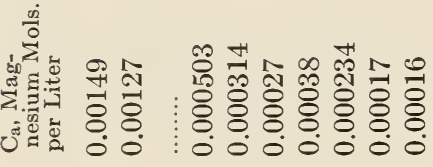

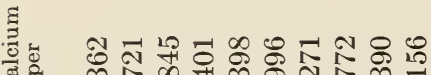
ชึ.

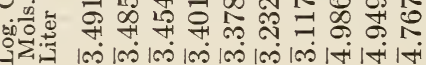

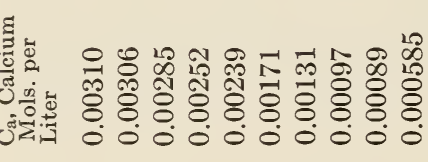
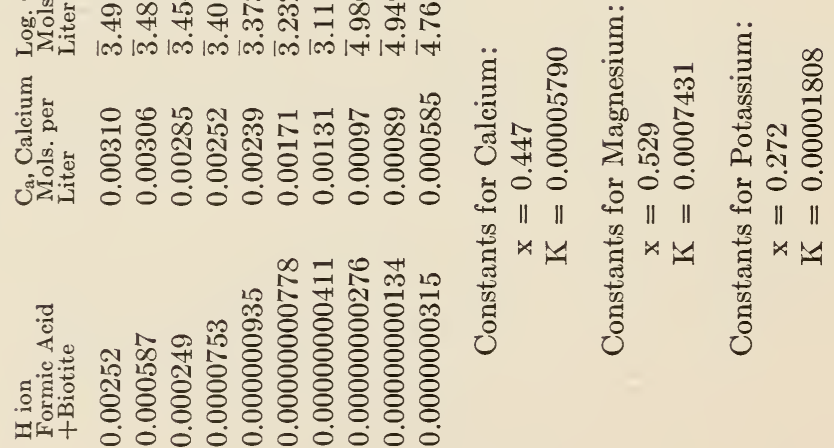
5

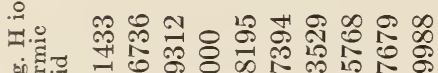

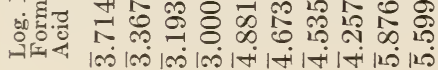

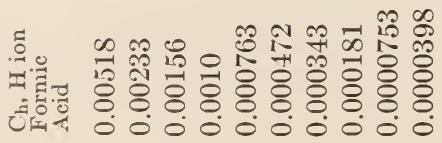

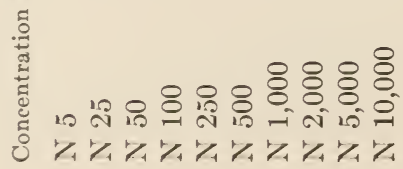




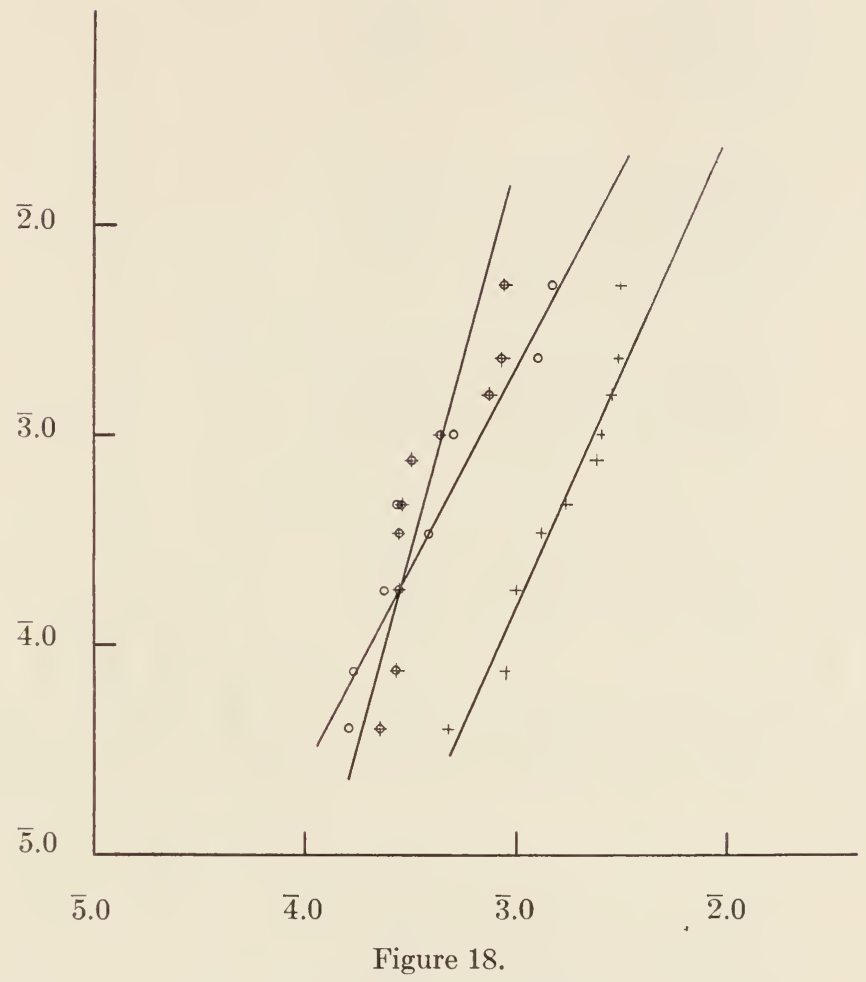

Formic Acid and Biotite.

(See Table 18) 


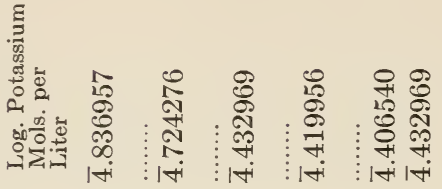

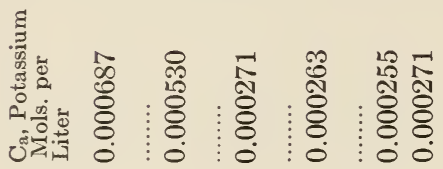

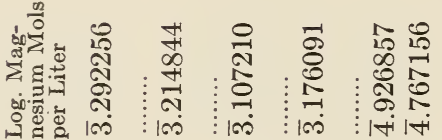

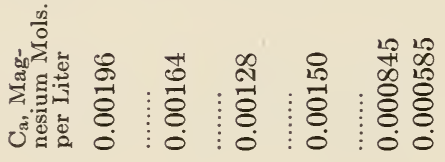

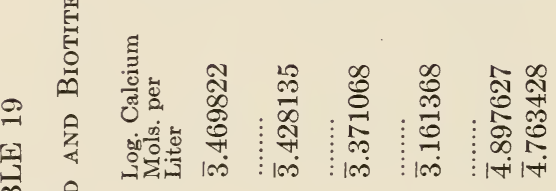

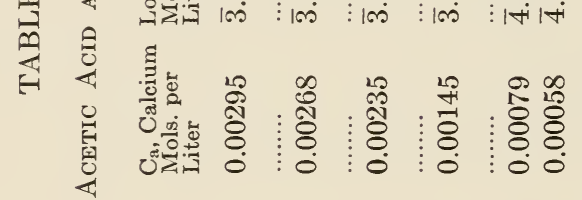

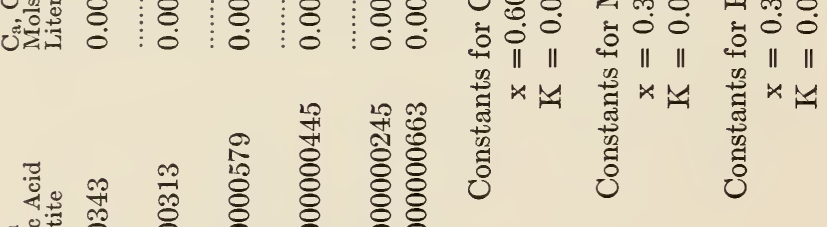

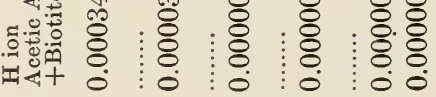

。

ت.

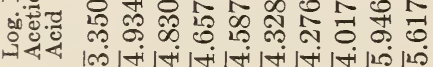

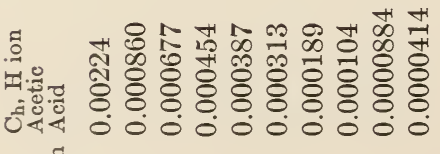

:

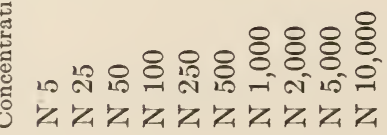




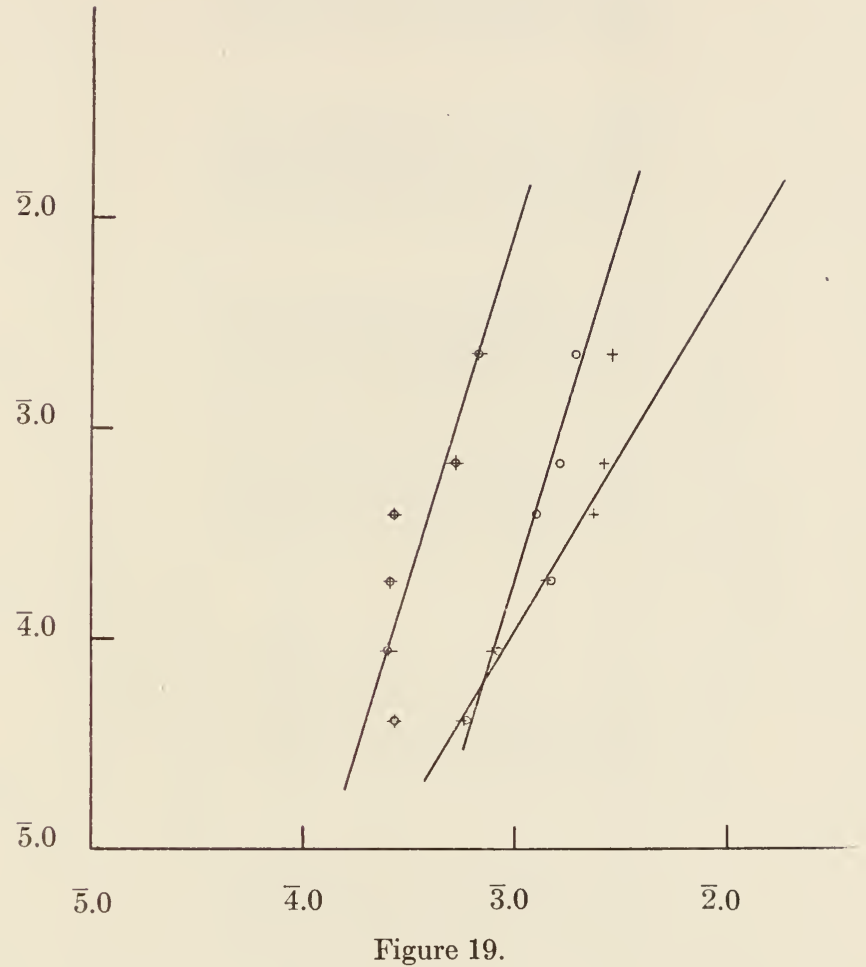

Acetic Acid and Biotite.

(See Table 19) 


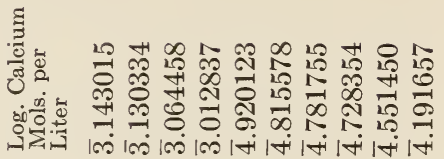

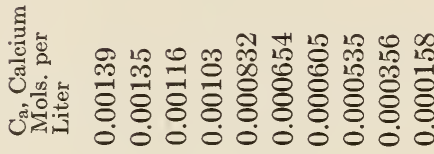

घ

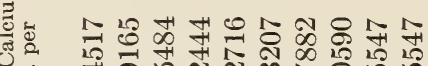

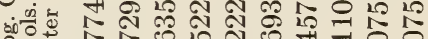

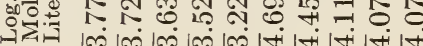

घี.

चึ:

vึ:

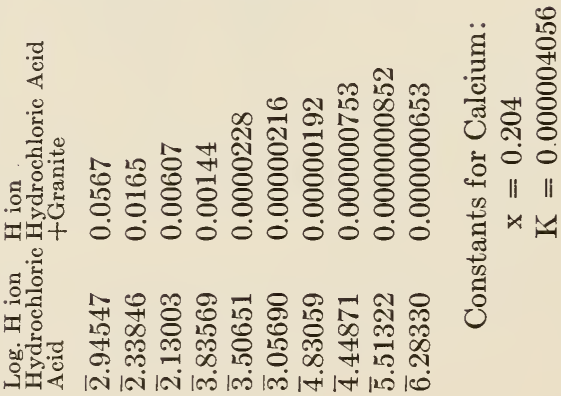

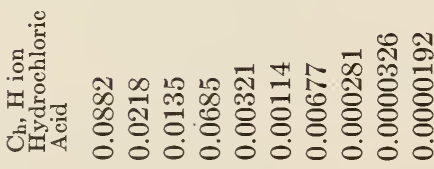

.

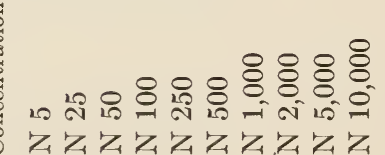




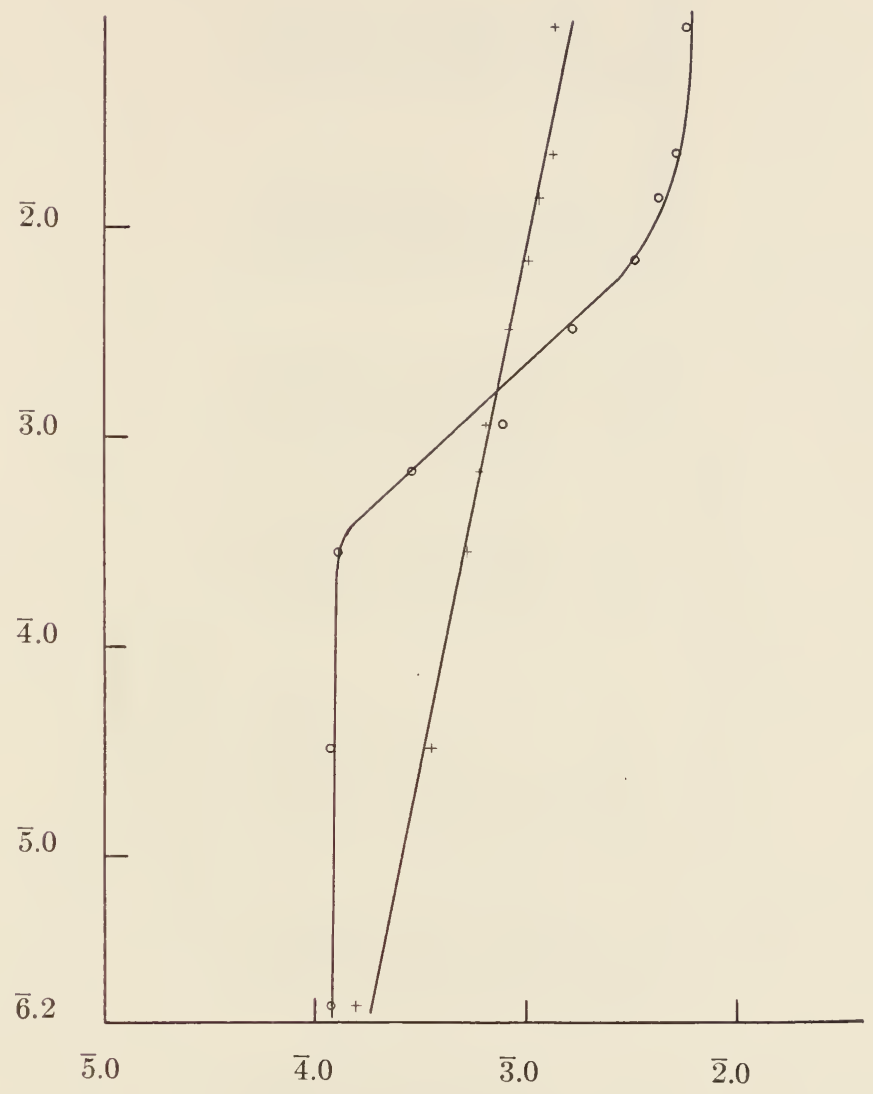

Figure 20.

Hydrochloric Acid and Granite.

(See Table 20) 


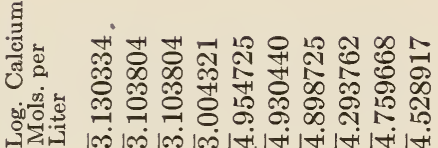

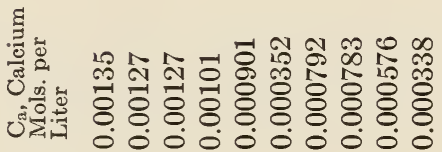

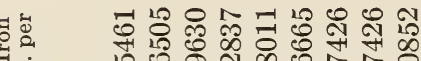

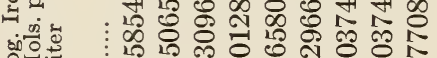

nin

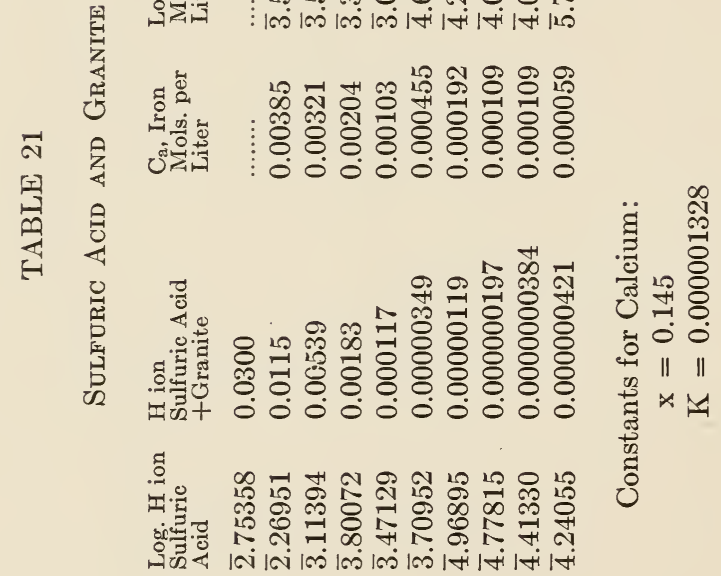

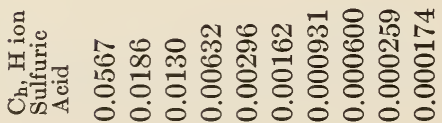

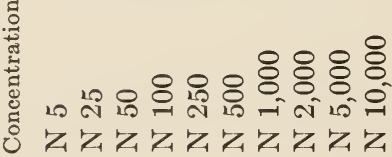




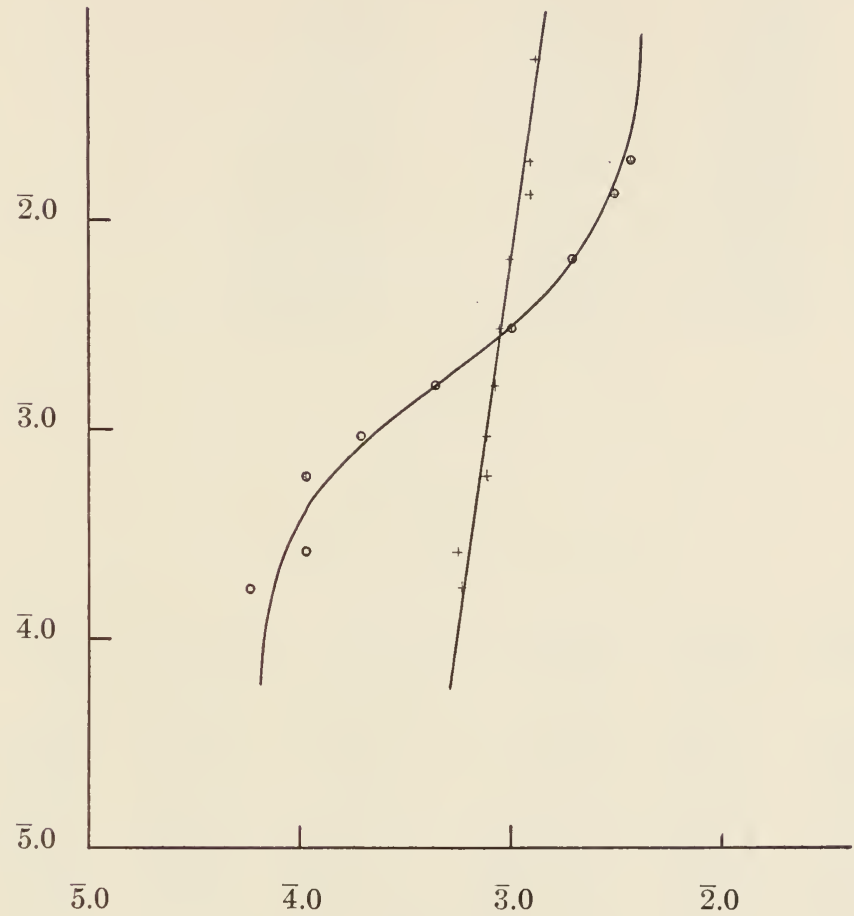

Figure 21.

Sulfuric Acid and Granite.

(See Table 21) 
TABLE 22

$\begin{array}{lllllc}\text { Concentration } & \begin{array}{l}\mathrm{C}_{\mathrm{h}}, \mathrm{H} \text { ion } \\ \text { Oxalic } \\ \text { Acid }\end{array} & \begin{array}{l}\text { Log. H ion } \\ \text { Oxalic } \\ \text { Acid }\end{array} & \begin{array}{l}\mathrm{H} \text { ion } \\ \text { Oxalic Acid } \\ \text { +Granite }\end{array} & \begin{array}{l}\text { Ca, Iron } \\ \text { Mols. per } \\ \text { Liter }\end{array} & \begin{array}{l}\text { Log. Iron } \\ \text { Mols. per } \\ \text { Liter }\end{array} \\ \text { N } 5 & 0.0213 & \overline{2} .33846 & 0.0255 & \ldots \ldots \ldots & \ldots \ldots \ldots \\ \text { N } 25 & 0.0110 & \overline{2} .04139 & 0.00772 & \ldots \ldots \ldots & \ldots \ldots \ldots \\ \text { N } 50 & 0.00561 & \overline{3} .74896 & 0.00226 & \ldots \ldots \ldots & \ldots \ldots \ldots \\ \text { N } 100 & 0.00347 & \overline{3} .54033 & 0.00000129 & \ldots \ldots \ldots & \ldots \ldots \ldots \\ \text { N } 250 & 0.00169 & \overline{3} .22789 & 0.0000141 & \ldots \ldots \ldots & \ldots \ldots \ldots \\ \text { N } 500 & 0.00105 & \overline{3} .02119 & 0.00000254 & \ldots \ldots \ldots & \ldots \ldots \ldots \\ \text { N } 1,000 & 0.000554 & \overline{4} .74351 & 0.000000863 & \ldots \ldots \ldots & \ldots \ldots \ldots \\ \text { N } 2,000 & 0.000317^{-} & \overline{4} .50106 & 0.000000421 & \ldots \ldots \ldots & \ldots \ldots \ldots \\ \text { N } 5,000 & 0.000132 & \overline{4} .12057 & 0.000000241 & \ldots \ldots \ldots & \ldots \ldots \ldots \\ \text { N } 10,000 & 0.0000785 & \overline{5} .89487 & 0.000000261 & \ldots \ldots \ldots & \ldots \ldots \ldots\end{array}$

TABLE 23

Phosphoric Acid and Granite

\begin{tabular}{|c|c|c|c|c|c|c|c|}
\hline $\begin{array}{l}\text { Concen- } \\
\text { tration }\end{array}$ & $\begin{array}{l}\mathrm{Ch}_{\mathrm{h}}, \mathrm{H} \text { ion } \\
\text { Phosphoric } \\
\text { Acid }\end{array}$ & $\begin{array}{l}\text { Log. H ion } \\
\text { Phosphoric } \\
\text { Acid }\end{array}$ & $\begin{array}{l}\text { H ion } \\
\text { Phosphoric Acid } \\
\text { +Granite }\end{array}$ & $\begin{array}{l}\mathrm{C}_{\mathrm{a}} \text {, Iron } \\
\text { Mols. per } \\
\text { Liter }\end{array}$ & $\begin{array}{l}\text { Log. Iron } \\
\text { Mols. per } \\
\text { Liter }\end{array}$ & $\begin{array}{l}\mathrm{C}_{\mathrm{a}} \text {, Calcium } \\
\text { Mols. per } \\
\text { Liter }\end{array}$ & $\begin{array}{l}\text { Log. Calci- } \\
\text { um Mols. } \\
\text { per Liter }\end{array}$ \\
\hline N 5 & 0.0125 & $\overline{2} .09691$ & 0.001 & 0.00496 & $\overline{3} .695482$ & 0.00174 & $\overline{3} .232996$ \\
\hline N 25 & 0.00632 & $\overline{3} .80072$ & 0.00296 & 0.00410 & $\overline{3} .612784$ & 0.000119 & $\overline{4} .075547$ \\
\hline N 50 & 0.00424 & $\overline{3} .62737$ & 0.0001 & 0.00351 & $\overline{3} .545307$ & 0.000178 & $\overline{4} .250420$ \\
\hline N 100 & 0.00273 & $\overline{3} .43616$ & 0.0000486 & 0.00716 & $\overline{3} .334454$ & 0.000515 & $\overline{4} .711807$ \\
\hline N 250 & 0.00144 & $\overline{3} .15836$ & 0.00000461 & 0.000675 & $\overline{4} .829304$ & 0.000505 & $\overline{4} .703291$ \\
\hline N 500 & 0.000762 & $\overline{4} .88195$ & 0.000000232 & 0.000308 & $\overline{4} .488551$ & 0.000416 & $\overline{4} .619093$ \\
\hline N 1,000 & 0.000372 & $\overline{4} .57054$ & 0.000000117 & 0.000188 & $\overline{4} .274158$ & 0.000436 & $\overline{4} .639486$ \\
\hline N 2,000 & 0.000213 & $\overline{4} .32838$ & 0.0000000787 & 0.000159 & $\overline{4} .201397$ & 0.000386 & $\overline{4} .586587$ \\
\hline N 5,000 & 0.0000642 & $\overline{5} .80754$ & 0.0000000961 & 0.000148 & $\underline{4} .170262$ & 0.000297 & $\overline{4} .472756$ \\
\hline N 10,000 & 0.0000431 & $\overline{5} .63448$ & 0.000000222 & 0.000119 & $\overline{4} .075547$ & 0.000376 & $\overline{4} .575188$ \\
\hline
\end{tabular}

Constants for Calcium:

$$
\begin{aligned}
\mathrm{x} & =0.136 \\
\mathrm{~K} & =0.000001987
\end{aligned}
$$




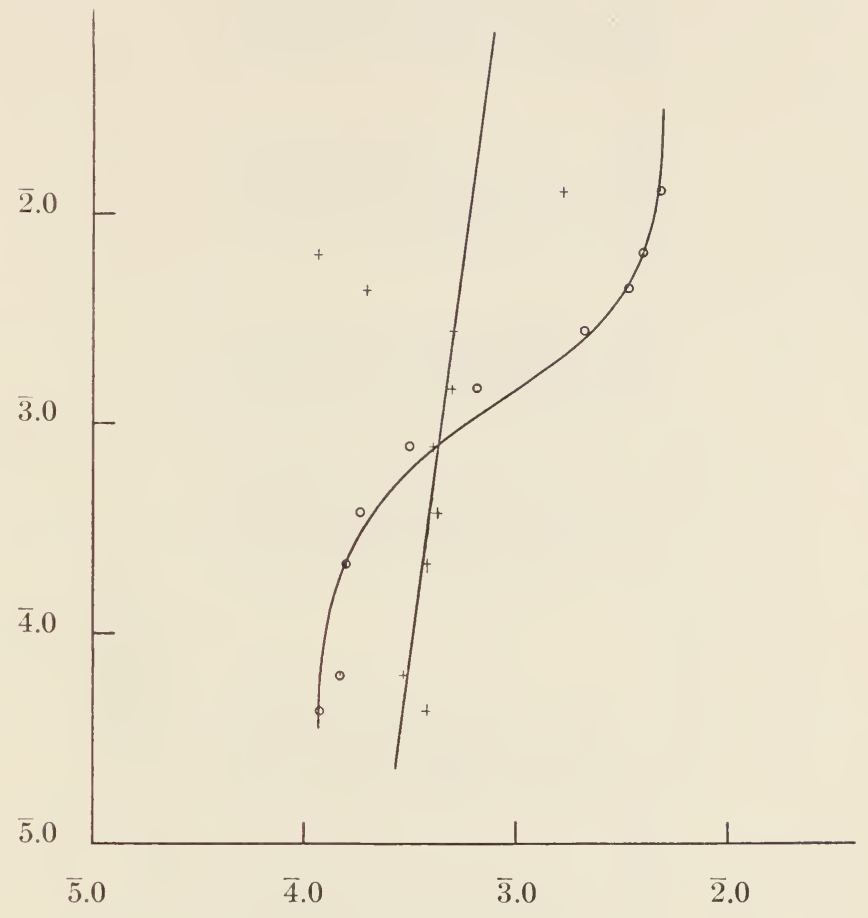

Figure 23.

Phosphoric Acid and Granite.

(See Table 23) 


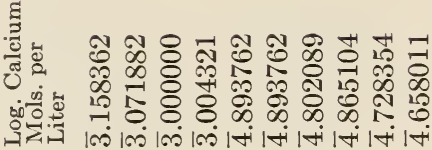

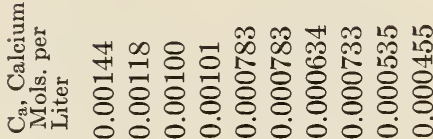

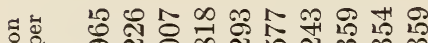
ㄴ.

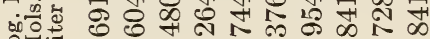

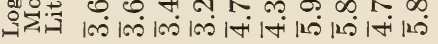
독

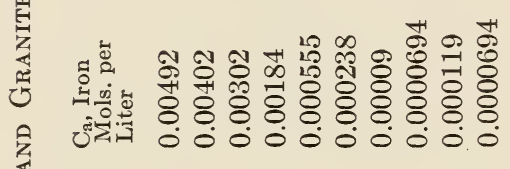

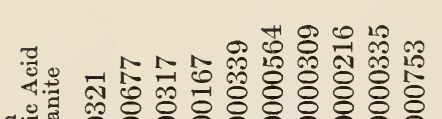
․ㅠㅆ

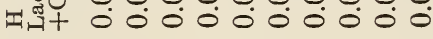
声

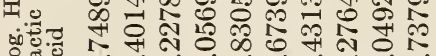

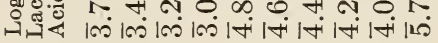

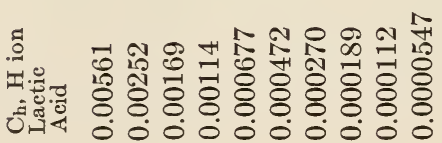

10

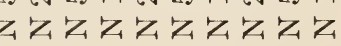




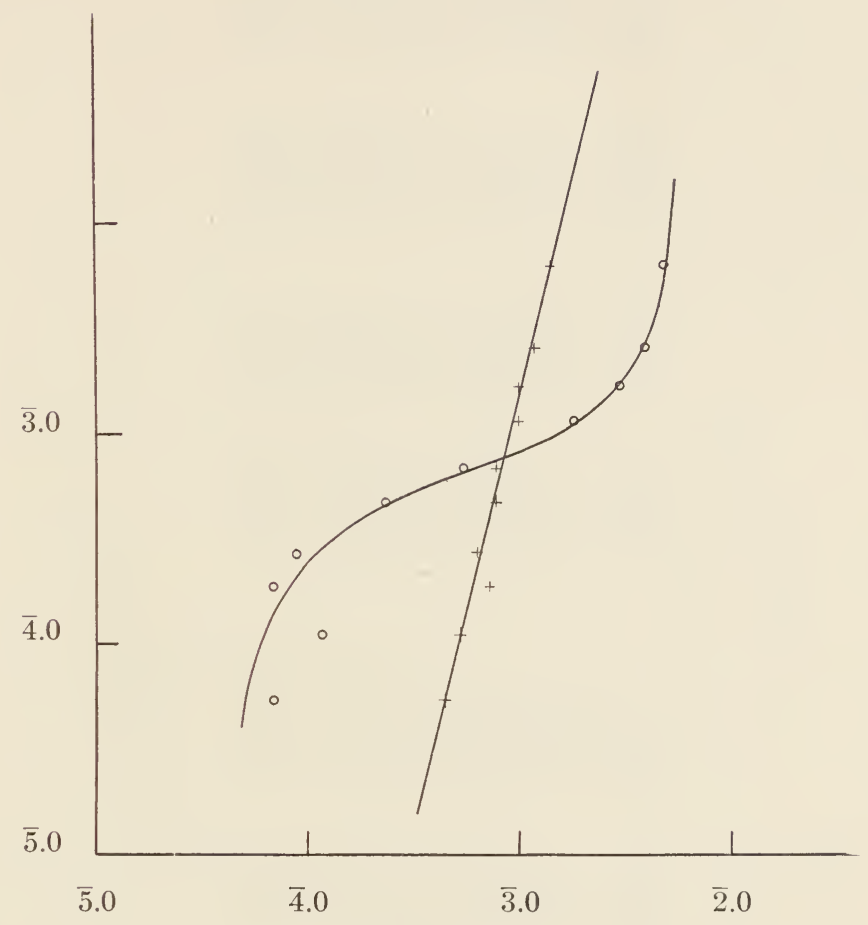

Figure 24.

Lactic Acid and Granite.

(See Table 24) 


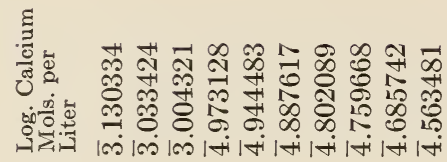

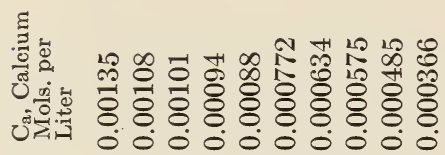

녕

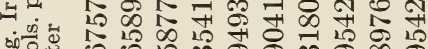

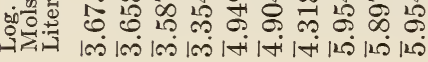

萌.

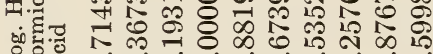

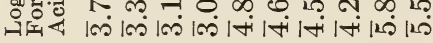

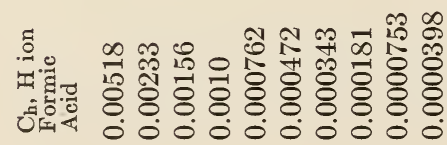

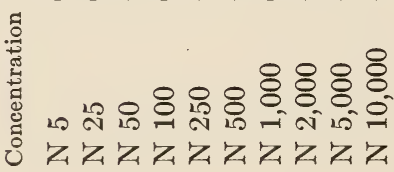




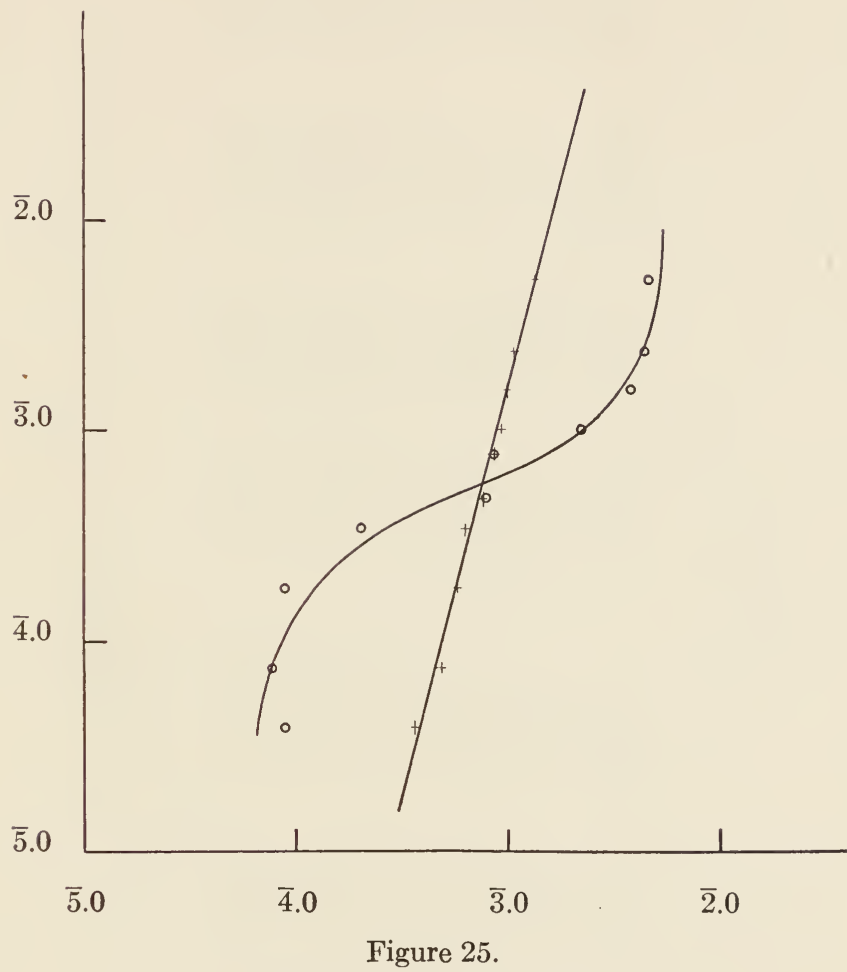

Formic Acid and Granite.

(See Table 25) 


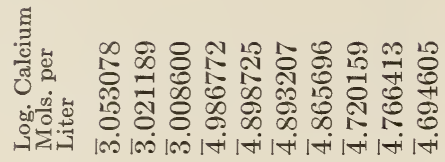

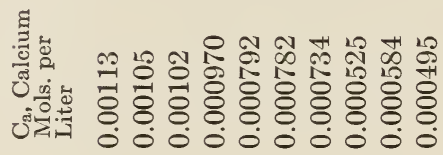

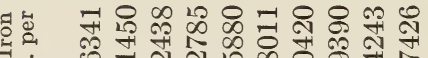

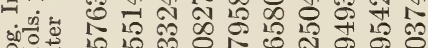

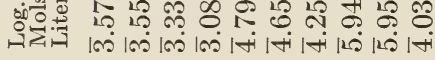

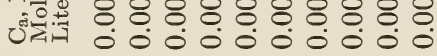

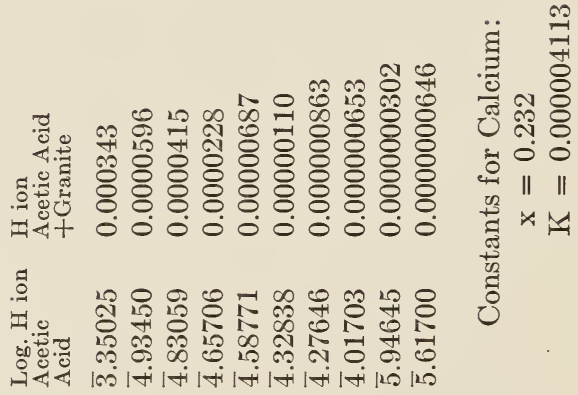

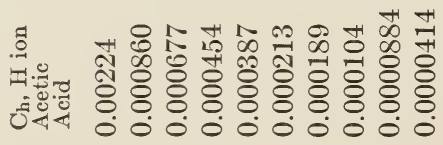

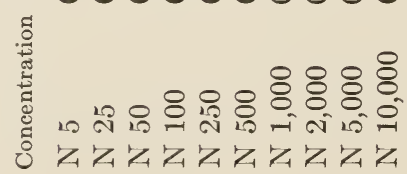




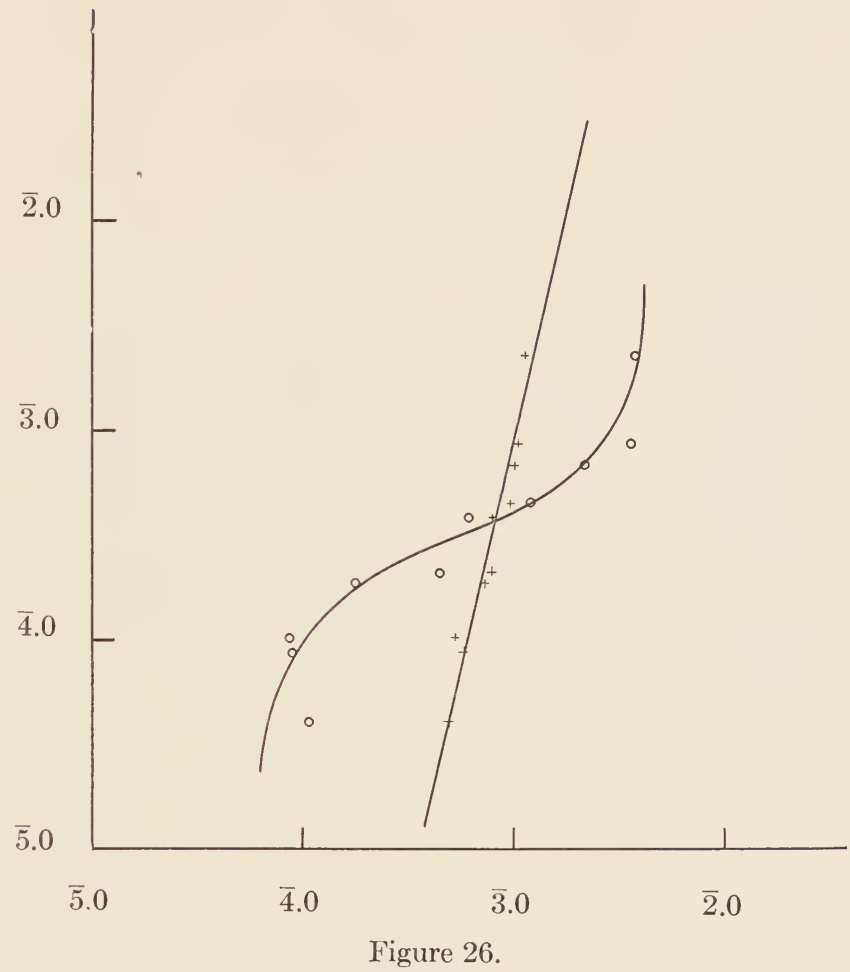

Acetic Acid and Granite.

(See Table 26) 
TABLE 27.

Orthoclase and Azotobacter.

$\begin{array}{clllll}\begin{array}{c}\text { Time } \\ \text { Days }\end{array} & \begin{array}{l}\mathrm{Ch}_{\mathrm{h}}, \mathrm{H} \text { ion } \\ \text { Dextrose } \\ \text { +Azotobacter }\end{array} & \begin{array}{l}\text { Log. H ion } \\ \text { Dextrose } \\ \text { +Azotobacter }\end{array} & \begin{array}{l}\mathrm{H} \text { ion } \\ \text { Orthoclase } \\ \text { +Azotobacter }\end{array} & \begin{array}{l}\text { Ca, Calcium } \\ \text { Mits. per } \\ \text { Liter }\end{array} & \begin{array}{l}\text { Log. Calcium } \\ \text { Mits. per } \\ \text { Liter }\end{array} \\ 0 & 0.00000282 & \overline{6} .450249 & 0.000000962 & 0.000238 & \overline{4} .376577 \\ 1 & 0.00000261 & \overline{6} .416641 & 0.000000787 & 0.000675 & \overline{4} .829304 \\ 2 & 0.00000331 & \overline{6} .519828 & 0.00000161 & 0.000455 & \overline{4} .658011 \\ 3 & 0.00000359 & \overline{6} .555094 & 0.000000887 & 0.000575 & \overline{4} .774517 \\ 5 & 0.00000421 & \overline{6} .624282 & 0.0000000887 & 0.000852 & \overline{4} .930440 \\ 7 & 0.00000534 & \overline{6} .727541 & 0.00000197 & 0.00107 & \overline{3} .029384 \\ 9 & 0.00000627 & \overline{6} .797268 & 0.00000251 & 0.00404 & \overline{3} .606381 \\ 11 & 0.00000935 & \overline{6} .970812 & 0.00000331 & 0.00198 & \overline{3} .296665 \\ 16 & 0.0000177 & \overline{5} .247973 & 0.00000389 & 0.00119 & \overline{3} .075547\end{array}$

Constants for Calcium:

$$
\begin{aligned}
\mathrm{X} & =1.804 \\
\mathrm{~K} & =19.77
\end{aligned}
$$




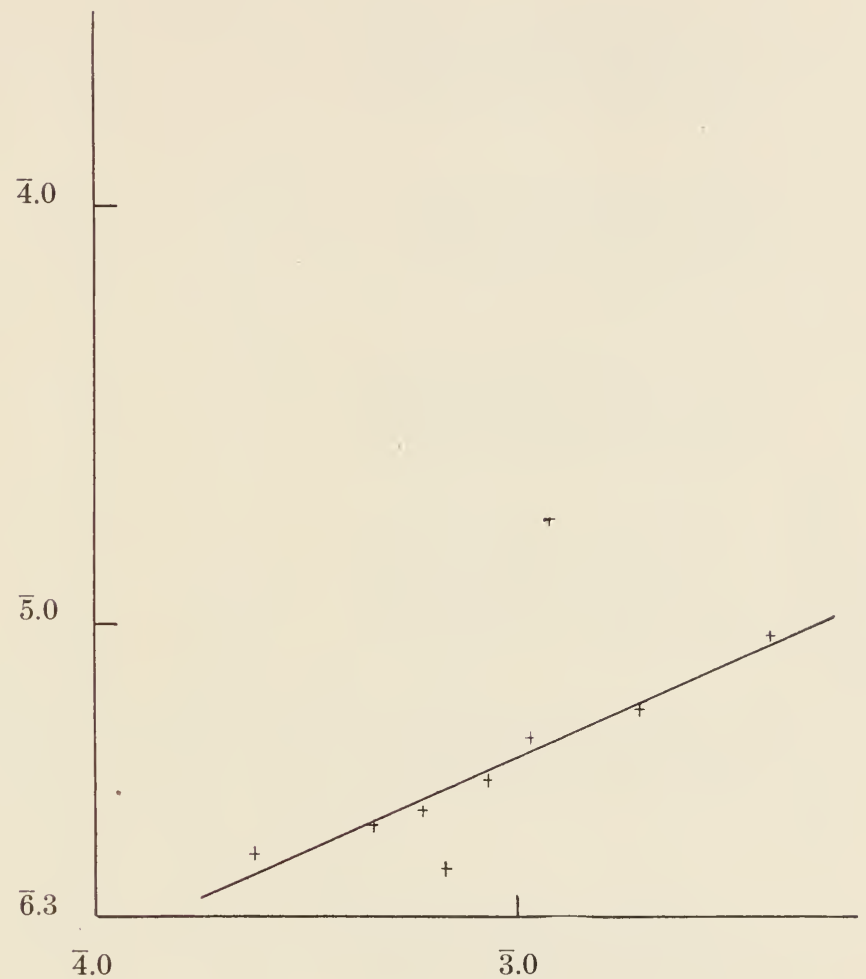

Figure 27.

Orthoclase and Azotobacter.

(See Table 27) 


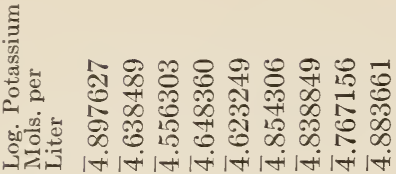

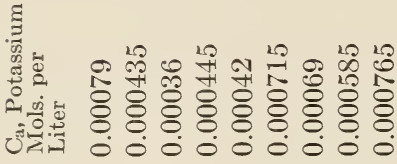

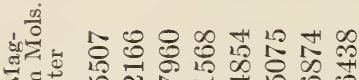

纯青

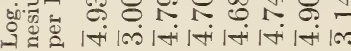

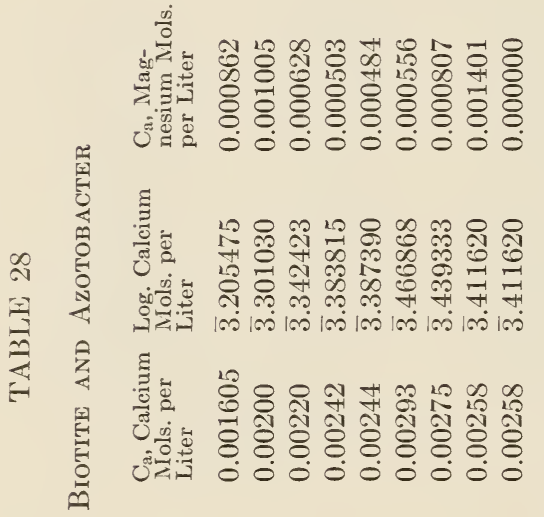

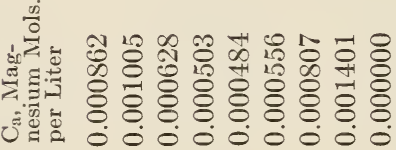

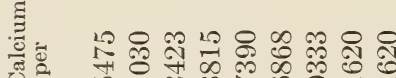

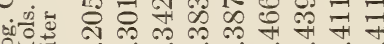

100100100100100100100100100

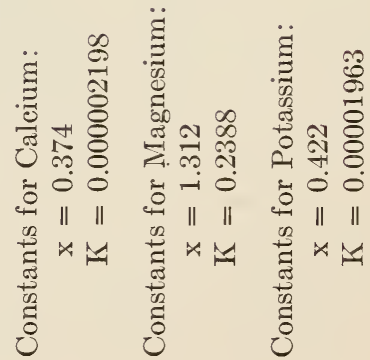

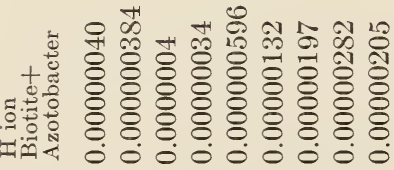

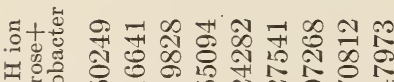

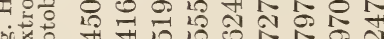

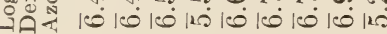

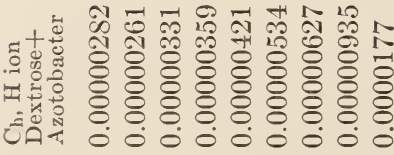

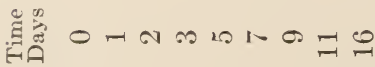




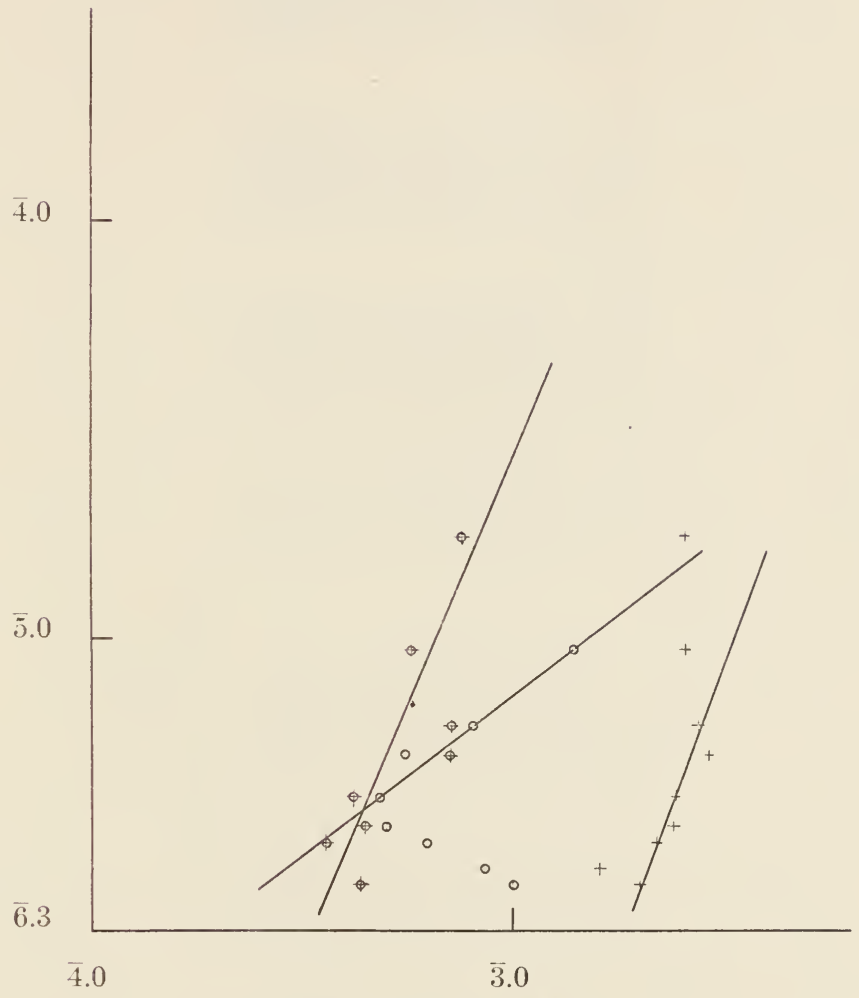

Figure 28.

Biotite and Azotobacter.

(See Table 28) 
范 vin

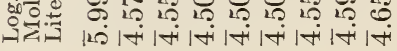

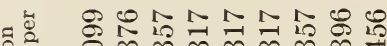

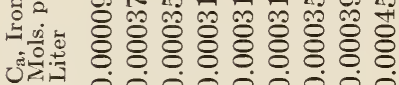
$\xi$

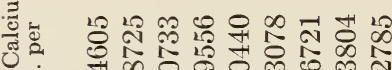

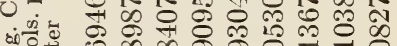
政活 苞

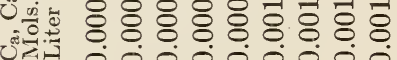

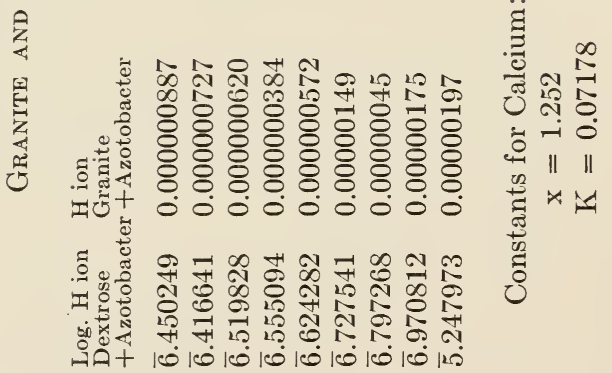

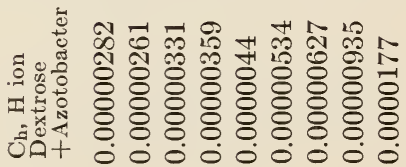

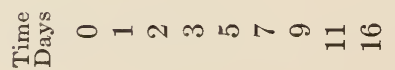




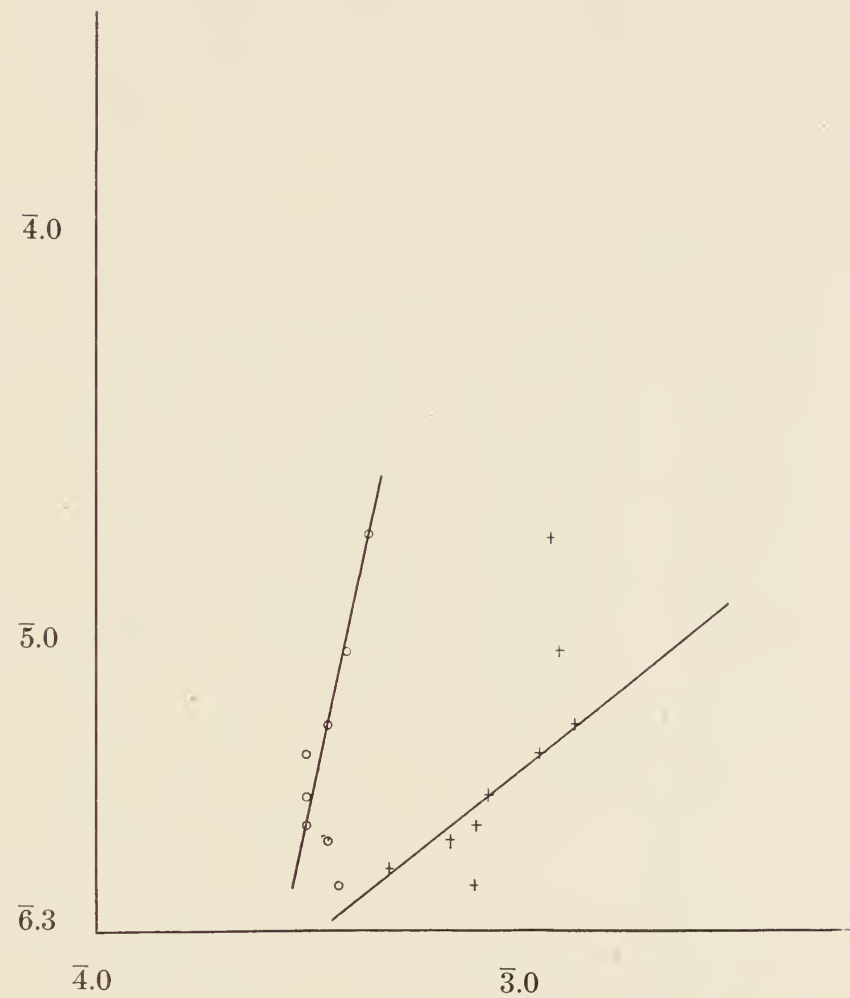

Figure 29.

Granite and Azotobacter.

(See Table 29) 
TABLE 30

Calcium Silicate and Azotobacter

$\begin{array}{clllll}\text { Time } & \begin{array}{l}\text { Ch, H ion } \\ \text { Dextrose } \\ \text { +Azotobacter }\end{array} & \begin{array}{l}\text { Log. H ion } \\ \text { Dextrose } \\ \text { +Azotobacter }\end{array} & \begin{array}{l}\text { H ion } \\ \text { Calcium Silicate } \\ \text { +Azotobacter }\end{array} & \begin{array}{l}\text { Ca, Calcium } \\ \text { Mols. per }\end{array} & \begin{array}{l}\text { Log. Calcium } \\ \text { Liter } \\ \text { Liter per }\end{array} \\ 0 & 0.00000282 & \overline{6} .450249 & 0.0000000778 & 0.00142 & \overline{3} .152288 \\ 1 & 0.00000261 & \overline{6} .416641 & 0.0000000778 & 0.00201 & \overline{3} .303196 \\ 2 & 0.00000331 & \overline{6} .519828 & 0.0000000912 & 0.00186 & \overline{3} .269513 \\ 3 & 0.00000359 & \overline{6} .555094 & 0.0000000912 & 0.00196 & \overline{3} .292256 \\ 5 & 0.00000421 & \overline{6} .624282 & 0.0000000112 & 0.00279 & \overline{3} .445604 \\ 7 & 0.00000534 & \overline{6} .727541 & 0.0000000941 & \ldots \ldots \ldots & \ldots \ldots \ldots \\ 9 & 0.00000935 & \overline{6} .797268 & 0.000000107 & 0.00396 & \overline{3} .597695 \\ 11 & 0.00000935 & \overline{6} .960812 & 0.0000000778 & 0.00396 & \overline{3} .597695 \\ 16 & 0.0000177 & \overline{5} .247973 & 0.000000731 & 0.00406 & \overline{3} .695482\end{array}$

Constants for Calcium:

$$
\begin{aligned}
\mathrm{x} & =1,280 \\
\mathrm{~K} & =0.03381
\end{aligned}
$$




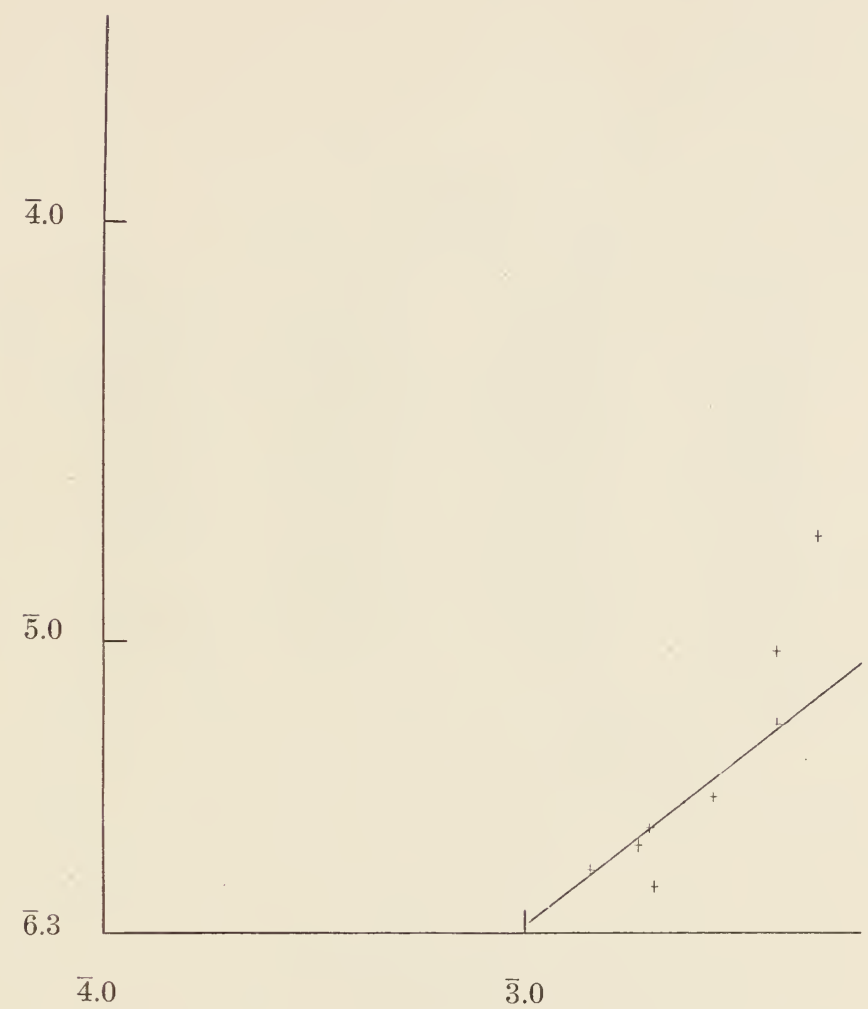

Figure 30 .

Calcium Silicate and Azotobacter.

(See Table 30) 
TABLE 31

Orthoclase and B. Coli

\begin{tabular}{|c|c|c|c|c|c|}
\hline $\begin{array}{l}\text { Time } \\
\text { Days }\end{array}$ & $\begin{array}{l}\mathrm{C}_{\mathrm{h}}, \mathrm{H} \text { ion } \\
\text { Dextrose } \\
\text { +B. Coli }\end{array}$ & $\begin{array}{l}\text { Log. H ion } \\
\text { Dextrose } \\
\text { +B. Coli }\end{array}$ & $\begin{array}{l}\text { H ion } \\
\text { Orthoclase } \\
\text { +B. Coli }\end{array}$ & $\begin{array}{l}\text { Ca, Calcium } \\
\text { Mols. per } \\
\text { Liter }\end{array}$ & $\begin{array}{l}\text { Log. Calcium } \\
\text { Mols.s. per } \\
\text { Liter }\end{array}$ \\
\hline 0 & 0.00000261 & $\overline{6} .416641$ & 0.000000962 & 0.000694 & $\overline{4} .841359$ \\
\hline 1 & 0.000301 & $\overline{4} .478566$ & 0.000141 & 0.000753 & $\overline{4} .876795$ \\
\hline 2 & 0.000486 & $\overline{4} .686636$ & 0.000267 & 0.00206 & $\overline{3} .313867$ \\
\hline 3 & 0.000505 & $\overline{4} .703291$ & 0.000339 & 0.00230 & $\overline{3} .361728$ \\
\hline 5 & 0.000505 & $\overline{4} .703291$ & 0.000289 & 0.00224 & $\overline{3} .350248$ \\
\hline 7 & 0.000467 & $\overline{4} .669317$ & 0.000278 & 0.00270 & $\overline{3} .431364$ \\
\hline 9 & 0.000414 & $\overline{4} .617000$ & 0.000237 & .......... & \\
\hline 11 & 0.000467 & $\overline{4} .669317$ & 0.000313 & 0.00282 & $\overline{3} .450249$ \\
\hline 16 & 0.000431 & $\overline{4} .634477$ & 0.000179 & 0.00271 & $\overline{3} .432969$ \\
\hline
\end{tabular}




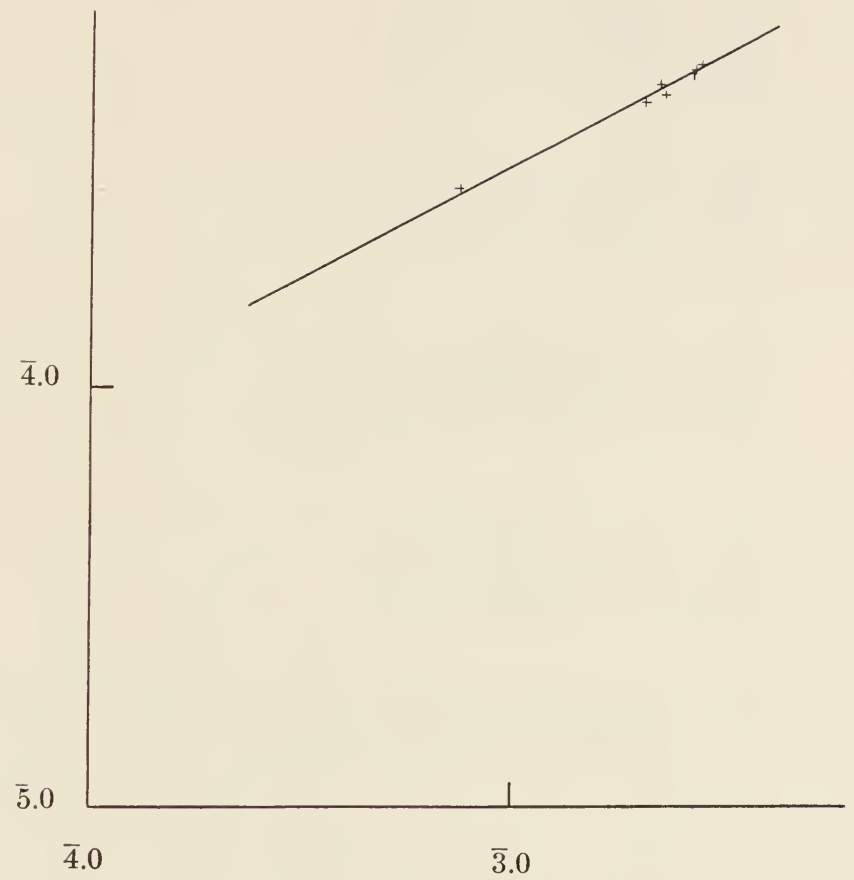

Figure 31 .

Orthoclase and B. Coli.

(See Table 31) 
:

范 in

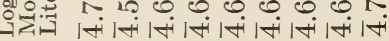

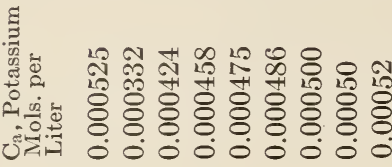

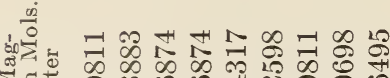

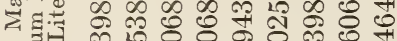
लीक के

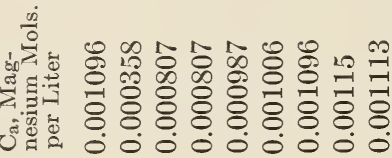

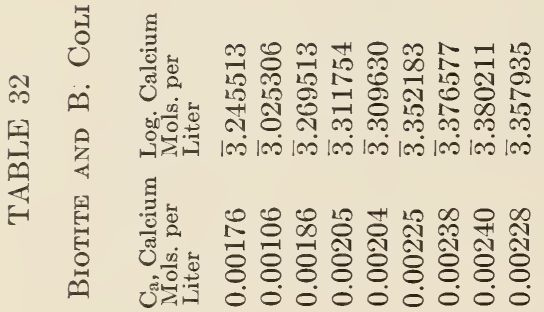

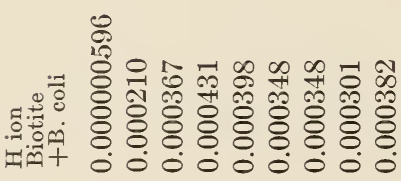

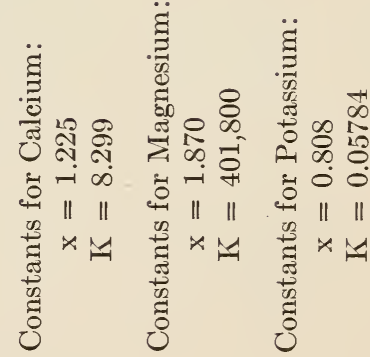

:

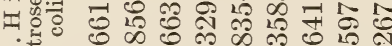

ơ

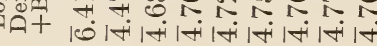

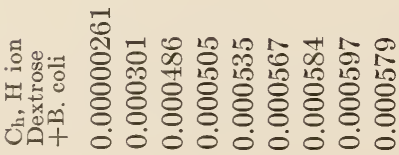

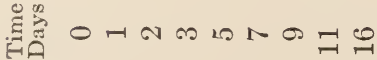




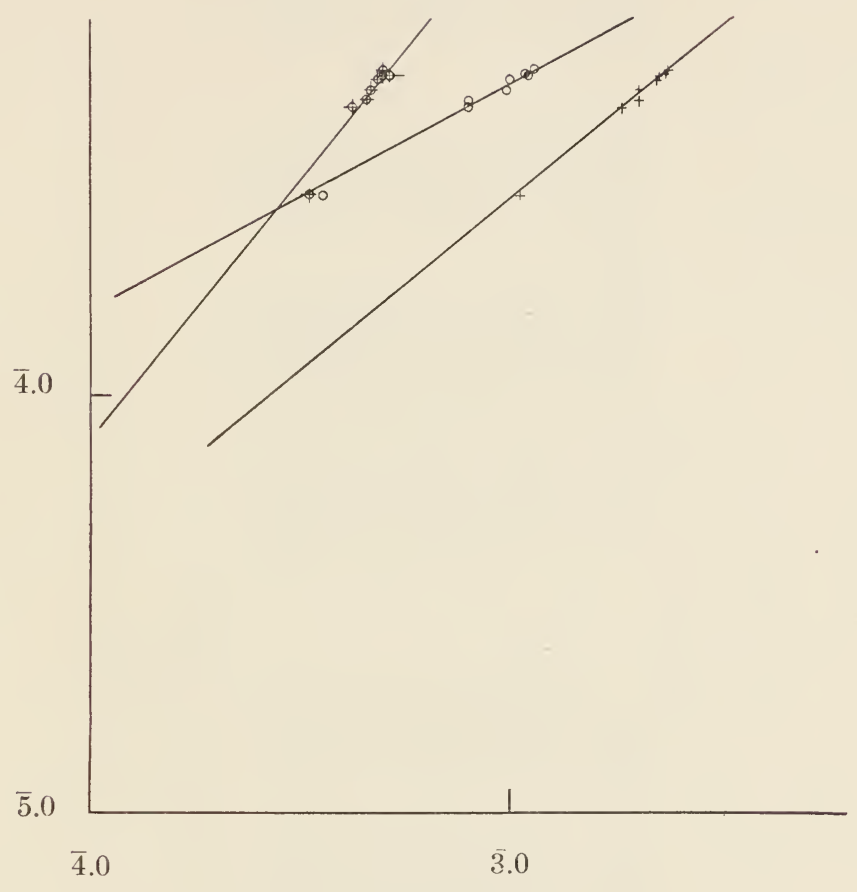

Figure 32.

Biotite and B. Coli.

(See Table 32) 
ㅁํㅇ N

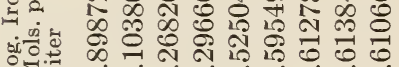
政热

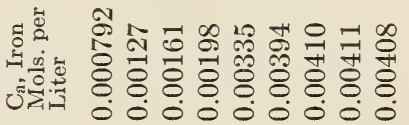

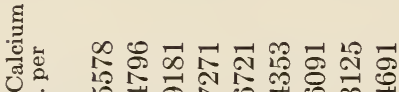
영

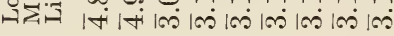
䎇

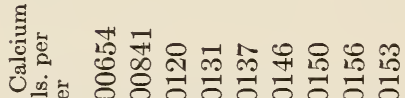
ن

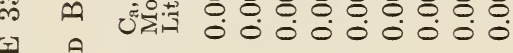
衰

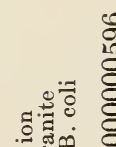

$\%$
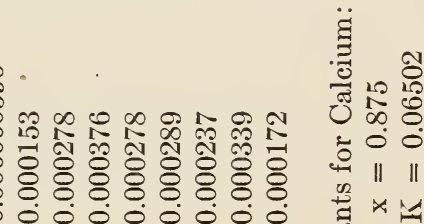

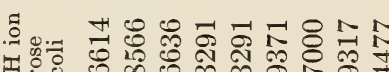

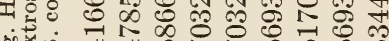

绍苗

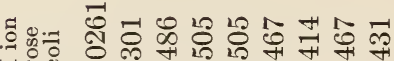
北

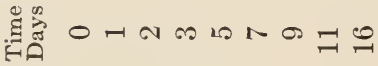




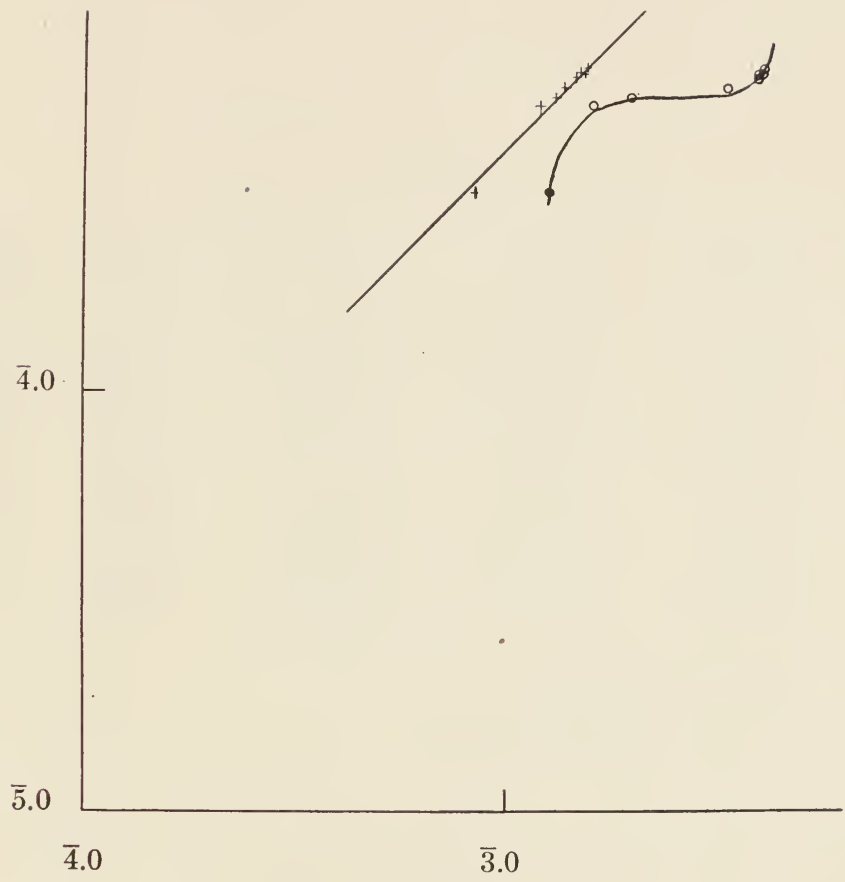

Figure 33.

Granite and B. coli.

(See Table 33) 
TABLE 34

Calcium Silicate and B. Coli

$\begin{array}{cl}\text { Time } & \begin{array}{l}\mathrm{Ch}_{h}, \mathrm{H} \text { ion } \\ \text { Dextrose } \\ \text { Days }\end{array} \\ 0 & 0.000000261 \\ 1 & 0.000301 \\ 2 & 0.000486 \\ 3 & 0.000505 \\ 5 & 0.000535 \\ 7 & 0.000567 \\ 9 & 0.000584 \\ 11 & 0.000597 \\ 16 & 0.000579\end{array}$

Log. H ion
Dextrose
+B. coli
$\overline{6} .416614$
$\overline{4} .478566$
$\overline{4} .686636$
$\overline{4} .703291$
$\overline{4} .728354$
$\overline{4} .753583$
$\overline{4} .766413$
$\overline{4} .775974$
$\overline{4} .762679$

$\mathrm{H}$ ion +B. coli

$\mathrm{C}_{a}$, Calcium Log. Calcium Mols. per Mols. per 0.000000220 Liter Liter

Constants for Calcium: $\begin{array}{lll}0.0000564 & 0.0397 & \overline{2} .598791\end{array}$ $\begin{array}{lll}0.0000687 & 0.0526 & \overline{2} .720986\end{array}$ $\begin{array}{lll}0.0000806 & 0.0723 & \overline{2} .859138\end{array}$ $\begin{array}{lll}0.0000745 & 0.0848 & \overline{2} .928396\end{array}$ $\begin{array}{lll}0.0000716 & 0.0972 & \overline{2} .987666\end{array}$ $\begin{array}{lll}0.0000716 & 0.1018 & \overline{1} .007748\end{array}$ $\begin{array}{lll}0.0000635 & 0.1238 & \overline{1} .092721\end{array}$

$$
\begin{aligned}
\mathrm{X} & =5.070 \\
\mathrm{~K} & =1,667 . \times 10^{11}
\end{aligned}
$$




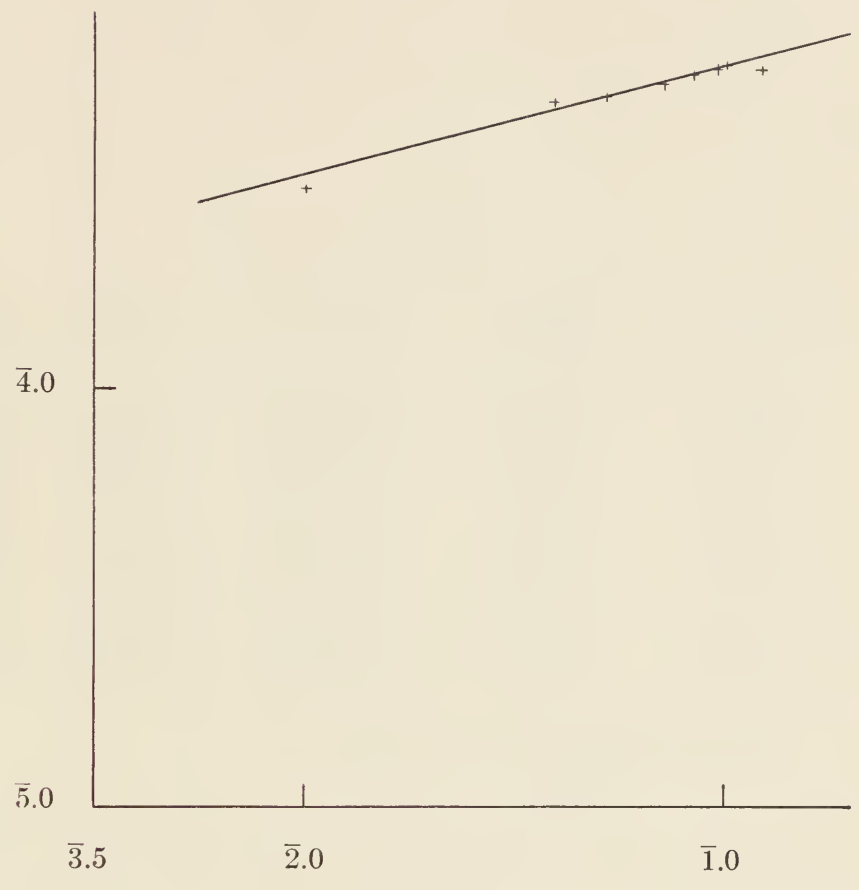

Figure 34 .

Calcium Silicate and B. coli.

(See Table 34) 
TABLE 35

Orthoclase and B. Lactis Acidi

$\begin{array}{clllll}\begin{array}{c}\text { Time } \\ \text { Days }\end{array} & \begin{array}{l}\begin{array}{l}\mathrm{C}_{\mathrm{h}}, \mathrm{H} \text { ion } \\ \text { Dextrose } \\ \text { +B. lactis acidi }\end{array} \\ 0\end{array} & \begin{array}{l}\text { Log. H ion } \\ \text { Dextrose } \\ \text { +B. lactis acidi }\end{array} & \begin{array}{l}\text { H ion } \\ \text { Orthoclase } \\ \text { +B. lactis acidi }\end{array} & \begin{array}{l}\text { Ca, Calcium } \\ \text { Mols. per } \\ \text { Liter }\end{array} & \begin{array}{l}\text { Log. Calcium } \\ \text { Mols. per } \\ \text { Liter }\end{array} \\ 1 & 0.00000421 & \overline{6} .624282 & 0.000000354 & 0.00147 & \overline{3} .167317 \\ 2 & 0.0000157 & \overline{5} .195900 & 0.00000935 & 0.000912 & \overline{4} .959995 \\ 3 & 0.000228 & \overline{4} .357935 & 0.00000967 & 0.000852 & \overline{4} .930440 \\ 5 & 0.000398 & \overline{4} .599883 & 0.00000967 & 0.00162 & \overline{3} .209515 \\ 7 & 0.000642 & \overline{4} .807535 & 0.0000217 & 0.00228 & \overline{3} .357935 \\ 9 & 0.000696 & \overline{4} .842609 & 0.0000170 & 0.00235 & \overline{3} .371068 \\ 11 & 0.000696 & \overline{4} .842609 & 0.0000192 & 0.00249 & \overline{3} .396199 \\ 16 & 0.000789 & \overline{4} .897077 & 0.0000244 & 0.00271 & \overline{3} .432969 \\ & 0.000642 & \overline{4} .807535 & 0.0000286 & 0.00210 & \overline{3} .322219\end{array}$

Constants for Calcium:

$$
\begin{aligned}
\mathrm{x} & =0.867 \\
\mathrm{~K} & =0.0006652
\end{aligned}
$$




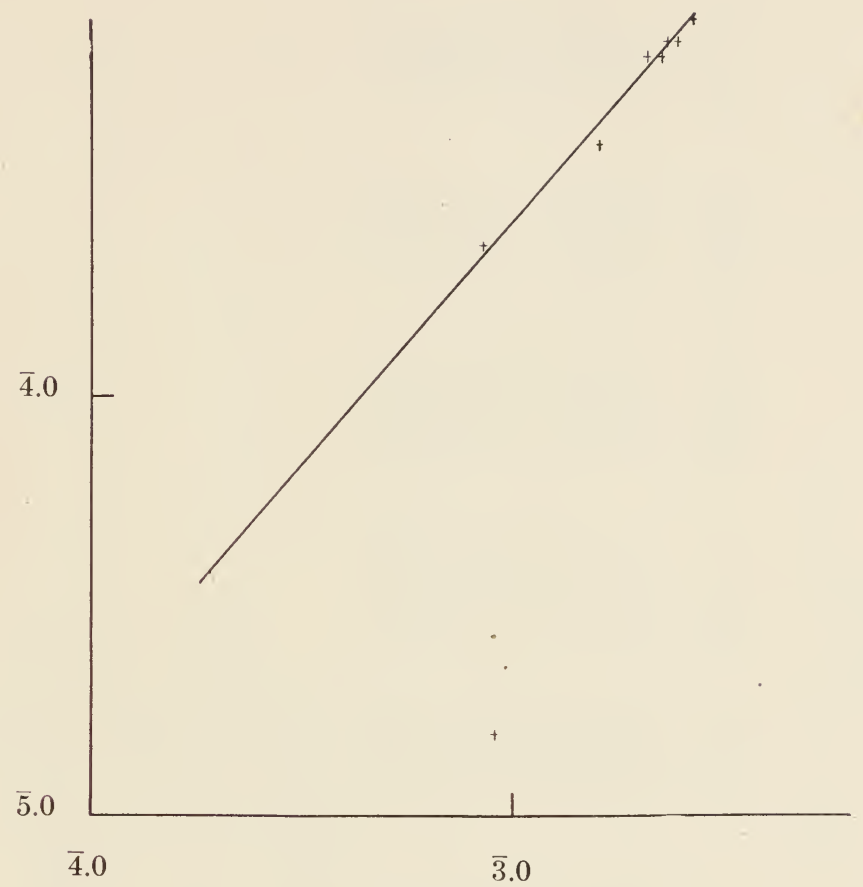

Figure 35.

Orthoclase and B. lactis acidi.

(See Table 35) 
离

융유류

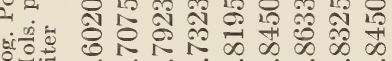

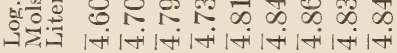

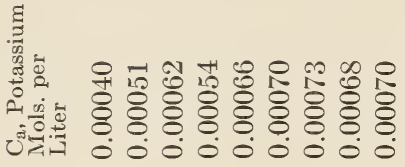

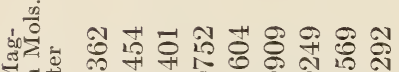
दू:

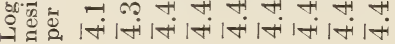

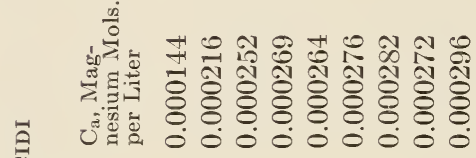

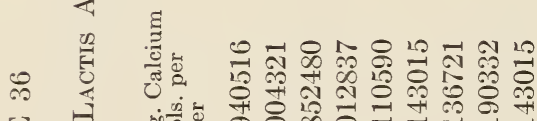

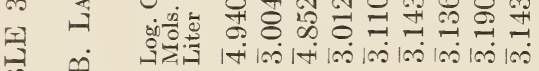
究各

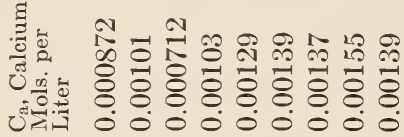

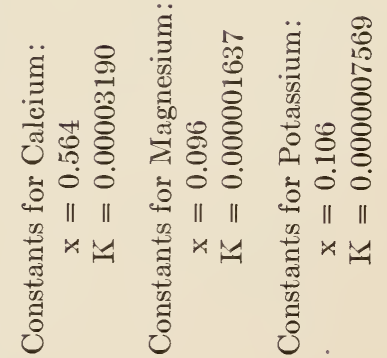

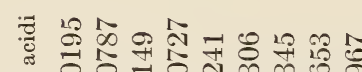

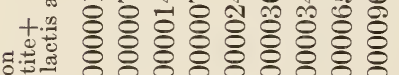
: 绝

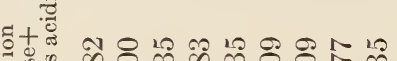

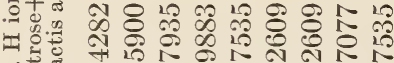

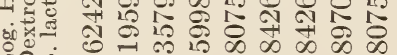

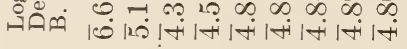

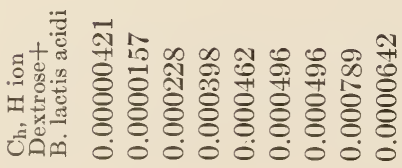
苞点 


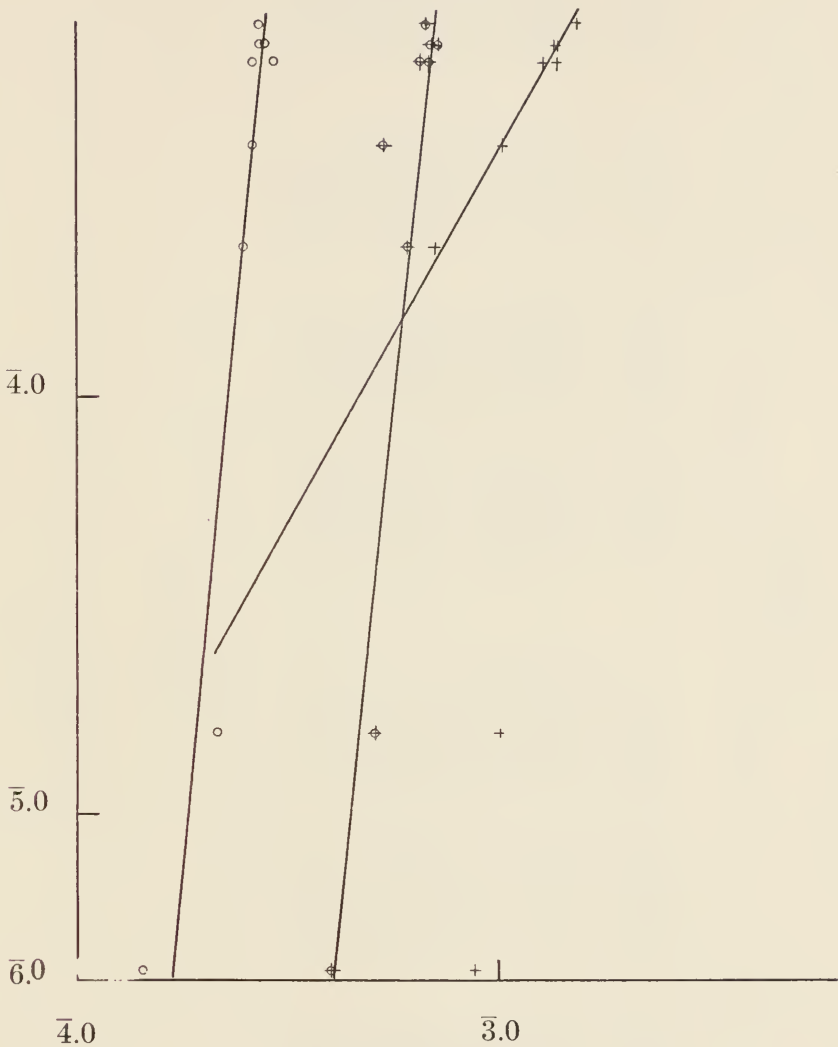

Figure 36.

Biotite and B. lactis acidi. (See Table 36) 


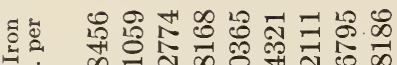
sion

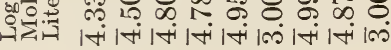

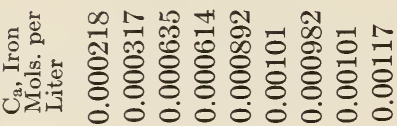

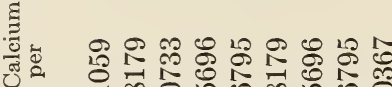

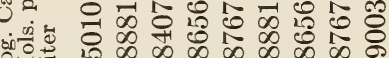

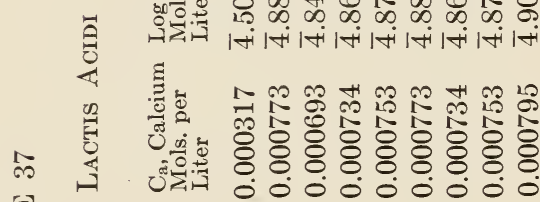

됙

学

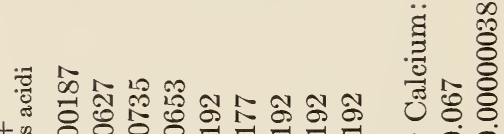

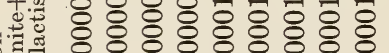

:

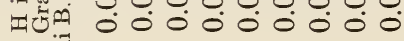

5ี+

4

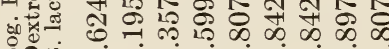

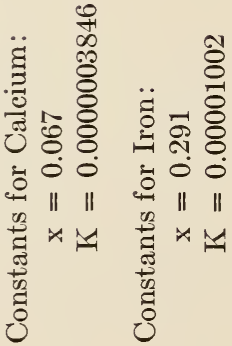

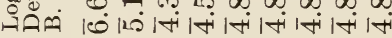

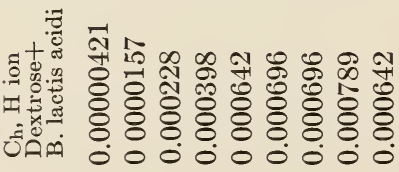

岁弯 0 - 


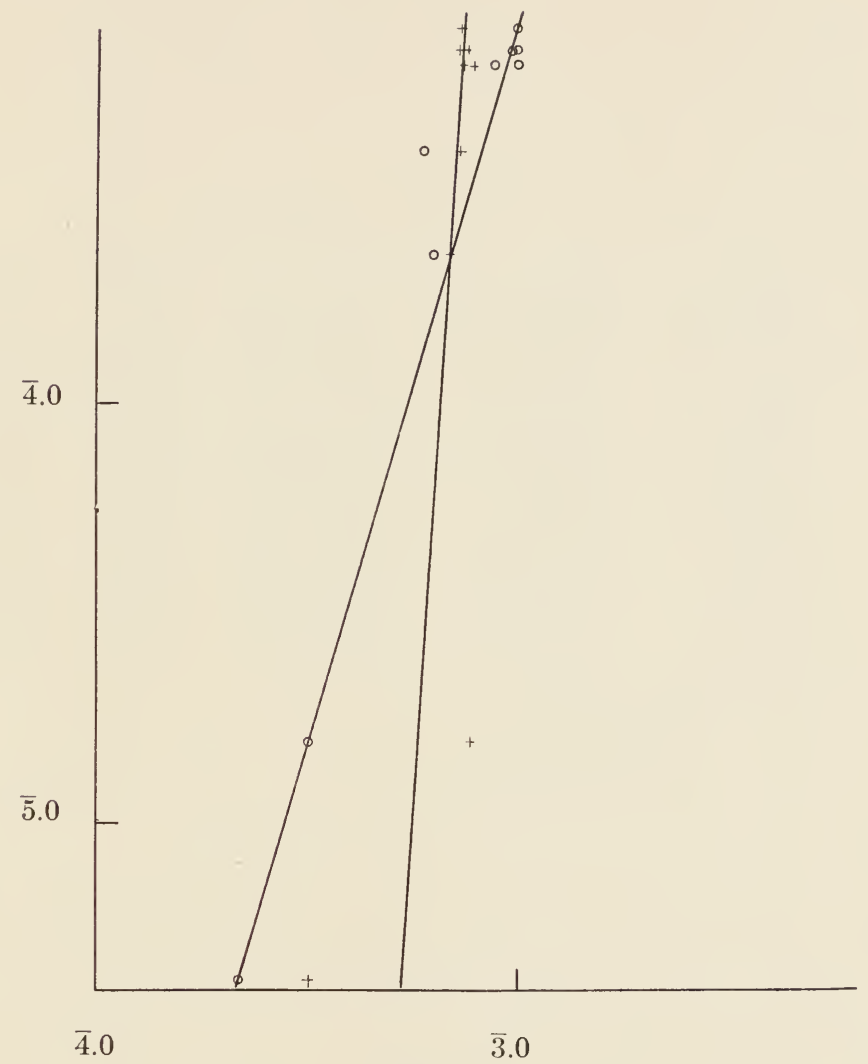

Figure 37.

Granite and B. lactis acidi.

(See Table 37) 
TABLE 38

Calcium Silicate and B. Lactis Acidi

$\begin{array}{clllll}\begin{array}{c}\text { Time } \\ \text { Days }\end{array} & \begin{array}{l}\mathrm{Ch}_{\mathrm{h}}, \mathrm{H} \text { ion } \\ \text { Dextrose } \\ \text { +B. lactis acidi }\end{array} & \begin{array}{l}\text { Log. } \mathrm{H} \text { ion } \\ \text { Dextrose } \\ \text { +B. lactis acidi }\end{array} & \begin{array}{l}\mathrm{H} \text { ion } \\ \text { Calcium Silicate } \\ \text { +B. lactis acidi }\end{array} & \begin{array}{l}\mathrm{C}_{\mathrm{a}} \text {, Calcium } \\ \text { Mols. per } \\ \text { Liter }\end{array} & \begin{array}{l}\text { Log. Calcium } \\ \text { Mols. per } \\ \text { Liter }\end{array} \\ 0 & 0.00000421 & \overline{6} .624282 & 0.0000000877 & 0.00229 & \overline{3} .359835 \\ 1 & 0.0000157 & \overline{5} .195900 & 0.000000136 & 0.00248 & \overline{3} .394452 \\ 2 & 0.000228 & \overline{4} .357935 & 0.000000142 & 0.00475 & \overline{3} .676694 \\ 3 & 0.000398 & \overline{4} .599883 & 0.0000000778 & 0.00416 & \overline{3} .619093 \\ 5 & 0.000642 & \overline{4} .807535 & 0.0000000778 & 0.00486 & \overline{3} .686636 \\ 7 & 0.000696 & \overline{4} .842609 & 0.0000000411 & 0.00554 & \overline{3} .743510 \\ 9 & 0.000696 & \overline{4} .842609 & 0.0000000544 & 0.00545 & \overline{3} .736397 \\ 11 & 0.000789 & \overline{4} .897077 & 0.0000000544 & 0.00525 & \overline{3} .720159 \\ 16 & 0.000642 & \overline{4} .807535 & 0.0000000544 & 0.00565 & \overline{3} .752048\end{array}$

Constants for Calcium:

$$
\begin{aligned}
\mathrm{x} & =0.170 \\
\mathrm{~K} & =0.0000002710
\end{aligned}
$$




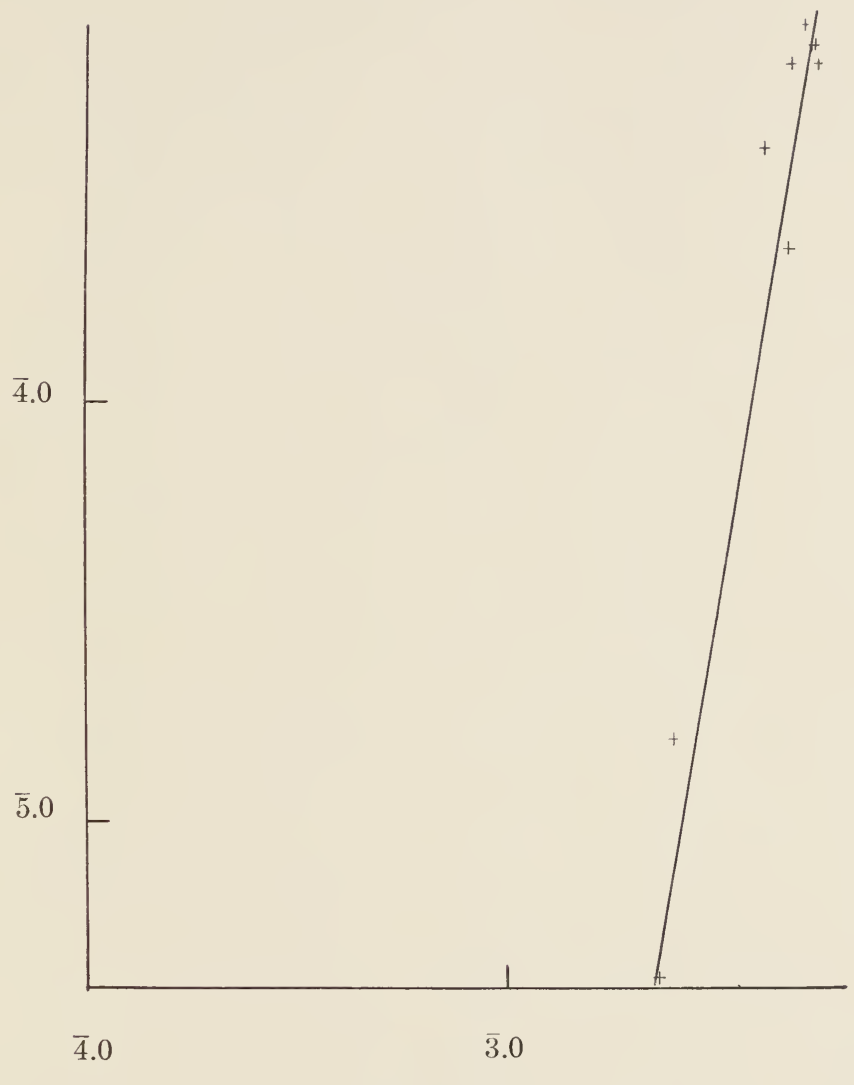

Figure 38.

Calcium Silicate and B. lactis acidi.

(See Table 38) 
